A ineficácia do direito à saúde do idoso
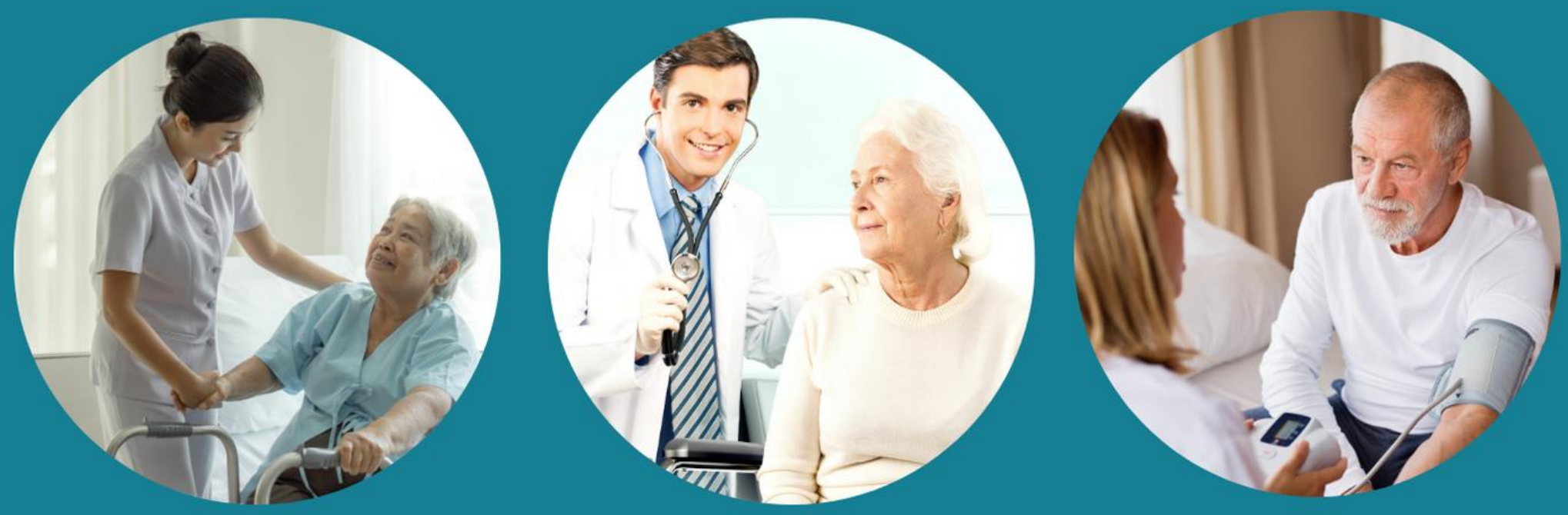

ORGANIZADORES

MYRIAM BENARRÓS

ROBERTA KARINA CABRAL KANZLER

SUELÂNIA CRISTINA GONZAGA DE FIGUEIREDO
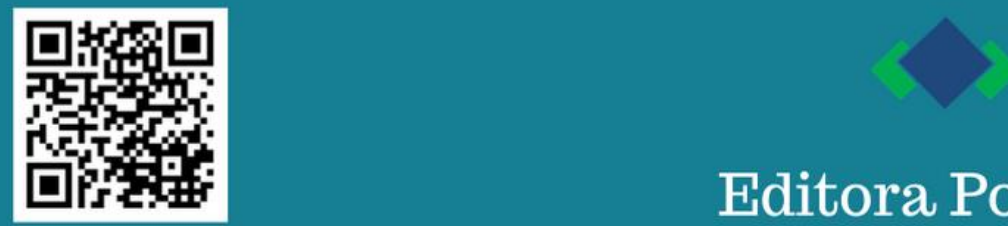

Editora Poisson 


\author{
(Organizadoras) \\ Myriam Benarrós \\ Roberta Karina Cabral Kanzler \\ Suelânia Cristina Gonzaga de Figueiredo
}

\title{
A ineficácia do direito à saúde do idoso
}

1므 Ediçao

Belo Horizonte

Poisson

2020 
Editor Chefe: Dr. Darly Fernando Andrade

\section{Conselho Editorial}

Dr. Antônio Artur de Souza - Universidade Federal de Minas Gerais Msc. Davilson Eduardo Andrade

Dra. Elizângela de Jesus Oliveira - Universidade Federal do Amazonas Msc. Fabiane dos Santos

Dr. José Eduardo Ferreira Lopes - Universidade Federal de Uberlândia Dr. Otaviano Francisco Neves - Pucminas

Dr. Luiz Cláudio de Lima - Universidade FUMEC

Dr. Nelson Ferreira Filho - Faculdades Kennedy

Msc. Valdiney Alves de Oliveira - Universidade Federal de Uberlândia

Dados Internacionais de Catalogação na Publicação (CIP)

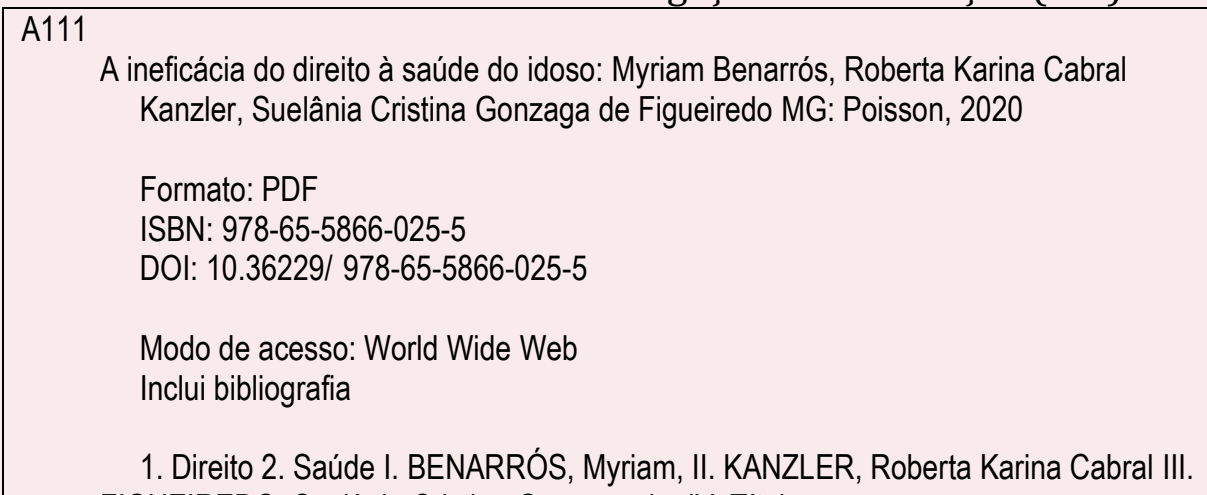

1. Direito 2. Saúde I. BENARRÓS, Myriam, II. KANZLER, Roberta Karina Cabral III. FIGUEIREDO, Suelânia Cristina Gonzaga de. IV. Título

Sônia Márcia Soares de Moura - CRB 6/1896

O conteúdo dos artigos e seus dados em sua forma, correção e confiabilidade são de responsabilidade exclusiva dos seus respectivos autores.

www.poisson.com.br

contato@poisson.com.br 
Projeto de Articulação Entre Pesquisa, Ensino, Extensão E Responsabilidade Social Institucional - PAPEERI

2018-2020

\section{CURSO DE DIREITO}

O presente volume contou com o apoio financeiro da Reitoria do Centro Universitário Ceuni-Fametro.

Nossos agradecimentos à

Magnífica Reitora Profa MSc MaRIa do CARMo SEFFAIR Lins de AlbuQuerQue 


\section{APRESENTAÇÃO}

O PAPEERI é um programa adotado pelo CEUNI-FAMETRO, cujo objetivo é promover a articulação entre Ensino, Pesquisa, Extensão e Responsabilidade Institucional, para a promoção de práticas de ensino, pesquisa, extensão e responsabilidade social na perspectiva da transversalidade.

Assim, este projeto nasce do consenso do colegiado docente do Curso de Bacharelado em Direito do CEUNI-FAMETRO, em 2018, tendo como temática: "O direito à saúde do idoso, direito ineficaz? A ineficácia do direito à saúde previsto no art. 196 da Constituição Federal", abordando o direito à saúde de todo idoso e o direito à vida, garantidos pela Constituição Federal, pelo Estatuto do Idoso e demais leis extravagantes.

A saúde é definida pela Organização Mundial de Saúde como "um estado de completo bem-estar físico, mental e social, e não consiste apenas na ausência de doença ou de enfermidade."

Nesse sentido, o direito à saúde está intimamente ligado ao princípio fundamental da Dignidade da Pessoa Humana, previsto no art. 1 da Constituição Federal de 1988 como fundamento do Estado Democrático de Direito, servindo de sustentáculo para outros princípios.

A Declaração Universal de Direitos Humanos (1948) em seu artigo 25, por sua vez, prescreve que "Todo ser humano tem direito a um padrão de vida capaz de assegurar a si e a sua família saúde e bem estar, inclusive alimentação, vestuário, habitação, cuidados médicos e os serviços sociais indispensáveis, e direito à segurança em caso de desemprego, doença, invalidez, viuvez, velhice ou outros casos de perda de subsistência em circunstâncias fora de seu controle".

Compreender o envelhecimento e suas necessidades em virtude das transformações ocorridas neste processo com o ser humano, requer uma visão, sob a ótica da inter e transdisciplinaridade, em virtude da complexidade do tema, além da importância de considerar a aplicação do princípio da solidariedade, previsto no artigo 3 da Constituição Federal de 1988, concebido não somente como um dispositivo legal, mas também como um instrumento de empatia e amor ao próximo.

É com esse olhar que se objetivou executar este projeto, visando-se oportunizar a aproximação do futuro operador de direito com a comunidade local e contribuir para uma melhor qualidade de vida dos idosos, conscientizando-os de quais sejam os seus direitos garantindo-se desta forma mais dignidade e cidadania para essa minoria vulnerável.

Se, por um lado, o projeto contribuiu sobremaneira para com a sociedade, por outro, proporcionou aos acadêmicos uma experiência que atende às expectativas previstas na Resolução n. 5, de 17 de dezembro de 2018 que institui as Diretrizes Curriculares Nacionais do Curso de graduação em Direito, a qual trata, especificadamente, do incentivo à pesquisa e à extensão, como fator necessário ao prolongamento da atividade de ensino e como instrumento para a iniciação científica.

0 projeto atende ao artigo 70 da Diretriz, que discorre sobre o estimulo à "realização de atividades curriculares de extensão ou de aproximação profissional que articulem o aprimoramento e a inovação de vivências relativas ao campo de formação, podendo, também, dar oportunidade de ações junto à comunidade ou de caráter social, tais como clínicas e projetos".

Além disso, este PAPEERI colaborou para articulação de novas competências e saberes necessários aos novos desafios que se apresentem no mundo do Direito, assegurando, no que concerne ao perfil do graduando, uma sólida formação geral e humanística, ou seja, um aprimoramento do desenvolvimento, bem-estar e dignidade do pensamento e ação humanos.

No que se refere às perspectivas formativas, as atividades realizadas possibilitaram oferecer aos acadêmicos, elementos fundamentais do Direito em diálogo com as demais expressões do conhecimento filosófico e humanístico, das ciências sociais.

Para tanto, a professora Renata da Silva Brito contribuiu com a matéria de Direito Constitucional, no que tange aos Direitos fundamentais e sociais, em particular ao Direito à saúde. A professora Myriam Benarrós, além de coordenar este PAPEERI, tratou dos aspectos civis e internacionais que envolvem a temática. A professora Maria do Perpétuo Socorro Oliveira participou orientando o projeto nos contornos previdenciários que a temática exige. 0 professor Renzzo Fonseca Romano forneceu as bases científicas acerca da judicialização do direito à saúde do idoso e por fim, o professor Dario Amaury Lopes, ajudou na pesquisa tratando das políticas públicas destinadas aos idosos, no âmbito do governo federal e das políticas públicas existentes para esse público em Manaus. 
Parabenizamos os acadêmicos e docentes que participaram ativamente deste projeto de inclusão social, solidariedade e fraternidade.

Após sua realização e conclusão, o CEUNI-FAMETRO por meio do Curso de Bacharelado em Direito, entrega à comunidade este e-book que descreve os resultados alcançados em benefício dos idosos da cidade de Manaus.

Roberta Karina Cabral Kanzler Coordenadora do Curso de Direito 


\section{ORGANIZADORAS}

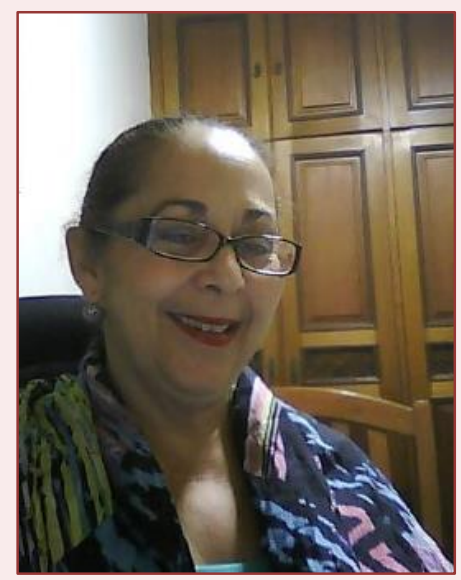

\section{Myriam Benarrós}

Doutora em Direito Civil pela Universidade de São Paulo, Mestre em Direito Romano e Sistemas Jurídicos pela Universidade de São Paulo, Especialista em Direito Romano pela Università di Roma 'La Sapienza', Especialista em Diritto dell'Informatica, Teoria e Tecniche dell'Informazione pela Università di Roma 'La Sapienza'. Foi, nos anos 2000-2011, pesquisadora do Consiglio Nazionale delle Ricerche-C.N.R (Itália). Atualmente é professora de Direito Civil e História do Direito no Centro Universitário CEUNI-FAMETRO (Manaus)

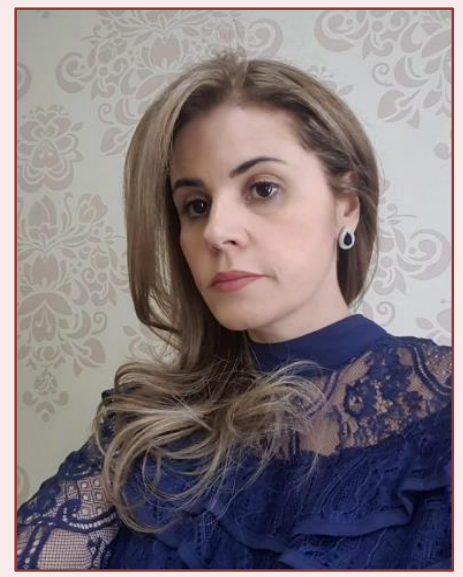

\section{Roberta Karina Cabral Kanzler}

Doutoranda em Direito (PUC-MF). Mestre em Ciência e Meio Ambiente pela UFPA. Especialista em Metodologia do Ensino Superior. Cursando Pós Graduação em Ciências Criminais. Bacharel em Direito Advogada - OAB - AM n. 8.950. Bacharel em Turismo. Possui experiência com educação superior, docência e projetos pedagógicos. Foi Coordenadora do Curso Superior em Tecnologia em Gestão em Turismo da Faculdade Barão do Rio Branco (UNINORTE) e Coordenadora Geral do Centro de Pós Graduação da UNINORTE - Rio Branco - AC. Tem experiência com docência na área de Criminologia, Prática Penal, Direito Penal, Direito processual Penal, Metodologia Científica e Trabalhos de Conclusão de Curso. Coordenadora do Curso de Graduação em Direito do Instituto Metropolitano de Ensino - IME. Avaliadora de Cursos de Graduação em Direito do SINAES - INEP (MEC). 


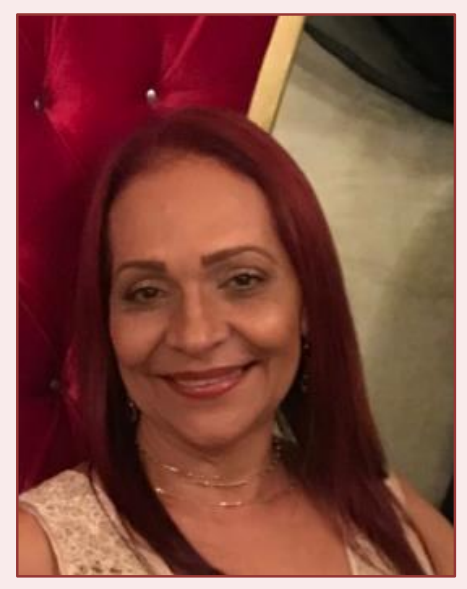

Suelânia Cristina Gonzaga de Figueiredo.

Possui graduação em Economia, mestrado em Desenvolvimento Regional e doutorado em Ciências da Educação. Atualmente é Coordenadora de Pesquisa e Extensão do Instituto Metropolitano de Ensino _ IME, atuando principalmente nos seguintes temas: Sustentabilidade, Pesquisa, Iniciação Cientifica, Produção acadêmica e Articulação entre Pesquisa, Ensino e Extensão. 


\section{SUMÁRIO}

Introdução

Capítulo 1: Aspectos Constitucionais

Renata da Silva Brito, Analice Cavalcante Pinto, Hávila K. Oliveira de Oliveira, Regina Celly da Costa .. DOI: 10.36229/ 978-65-5866-025-5.CAP.01

Capítulo 2: Aspectos civis e internacionais.

Myriam Benarrós, Tayana Souza da Silva, Yanca N. Ribeiro de Oliveira DOI: 10.36229/ 978-65-5866-025-5.CAP.02

Capítulo 3: Aspectos previdenciários. 35

Maria do Perpetuo Socorro Oliveira de Souza, Josany Keise de Souza David, Rebecca Cinque de Oliveira DOI: $10.36229 /$ 978-65-5866-025-5.CAP.03

Capítulo 4: As políticas públicas

Dario Amauri Lopes de Almeida, Alciney Januário de Souza, Alex Souza dos Santos Oliveira, Douglas Kanawati Madeira, Flávia C. da Silva Costa, Romeu dos Santos DOI: 10.36229/ 978-65-5866-025-5.CAP.04

Capítulo 5: A judicialização do direito à saúde do idoso 46

Renzzo Fonseca Romano, Luciana Beatriz Pinto Campelo, Maira de Souza Pontes DOI: $10.36229 /$ 978-65-5866-025-5.CAP.05

Capítulo 6: Conclusão 56

Renzzo Fonseca Romano

DOI: 10.36229/ 978-65-5866-025-5.CAP.06 


\section{Introdução}




\section{INTRODUÇÃO ${ }^{1}$}

Uma emenda apresentada pelo Fórum Nacional de Educação à Assembleia Nacional Constituinte, que propunha a indissociabilidade entre ensino, pesquisa e extensão como um novo paradigma para a universidade brasileira, foi incorporada à Constituição brasileira de 1988 em seu artigo 207, que estabelece: "As universidades gozam de autonomia didático-científica, administrativa e de gestão e obedecerão ao princípio da indissociabilidade entre ensino, pesquisa e extensão". O conceito de indissociabilidade entre ensino, pesquisa e extensão, como referência para a organização do trabalho pedagógico, embora de difícil concretização em face das condições políticas e estruturais da educação superior, tornou-se premissa para pensar e propor alternativas para esse nível de ensino, incorporando-se à história da universidade brasileira como contraponto aos modelos baseados na lógica do mercado 2 .

Em 06 de novembro de 1987 durante o I Encontro Nacional de Pró-Reitores de Extensão das universidades públicas, ocorrido na Universidade de Brasília-UnB, foi criado e implantado o Fórum Nacional de Pró-Reitores de Extensão das Universidades Públicas - FORPROEX, tendo como perspectiva a compreensão da extensão indicada anteriormente.

No Brasil, a extensão universitária teve distintas acepções ao longo do tempo, como difusão cultural ou científica, prestação de serviço, assistência, desenvolvimento, até a conceituação demarcada a partir da criação do FORPROEX, em que a extensão é compreendida como caminho de consolidação de responsabilidade e compromisso social e como dimensão intrínseca da formação acadêmica e do conhecimento produzidos na e pela Universidade. A perspectiva do conhecimento pluriversitário implica em um nível de responsabilidade social aprimorado, por parte da Universidade, e adentra mais diretamente na dimensão formativa da Extensão ${ }^{3}$.

No Brasil, de acordo com a proposição do FORPROEX, elaborada em 1987, e reiterada em documentos seguintes, inclusive no Plano Nacional de Extensão Universitária, de 1999, e no documento Política Nacional de Extensão Universitária, de 2012 a extensão é conceituada como:

[...] o processo educativo, cultural e científico que articula o ensino e a pesquisa de forma indissociável e viabiliza a relação transformadora entre a universidade e a sociedade. A extensão é uma via de mão-dupla, com trânsito assegurado à comunidade acadêmica, que encontrará, na sociedade, a oportunidade de elaboração da práxis de um conhecimento acadêmico. No retorno à universidade, docentes e discentes trarão um aprendizado que, submetido à reflexão teórica, será acrescido àquele conhecimento. Este fluxo, que estabelece a troca de saberes sistematizados/acadêmico e popular, terá como consequência: a produção de conhecimento resultante do confronto com a realidade brasileira e regional; e a democratização do conheci mento acadêmico e a participação efetiva da comunidade na atuação da universidade. Além de instrumentalizadora desse processo dialético de teoria/prática, a Extensão é um trabalho interdisciplinar que favorece a visão integrada do social. [...] Como um processo que permeia o ensino e a pesquisa, integrando essas atividades, a extensão deve ser parte indispensável da rotina universitária, institucionalizando-se tanto do ponto de vista administrativo como da prática acadêmica ${ }^{4}$.

Assim sendo, as diretrizes para o Ensino Superior delineiam Ensino, Pesquisa e Extensão como processos fundamentais e interligados na formação do graduando do CEUNI-FAMETRO. Dessa forma, a IES promove o processo de desenvolvimento e universalização da investigação científica, por meio de projetos de Iniciação Científica.

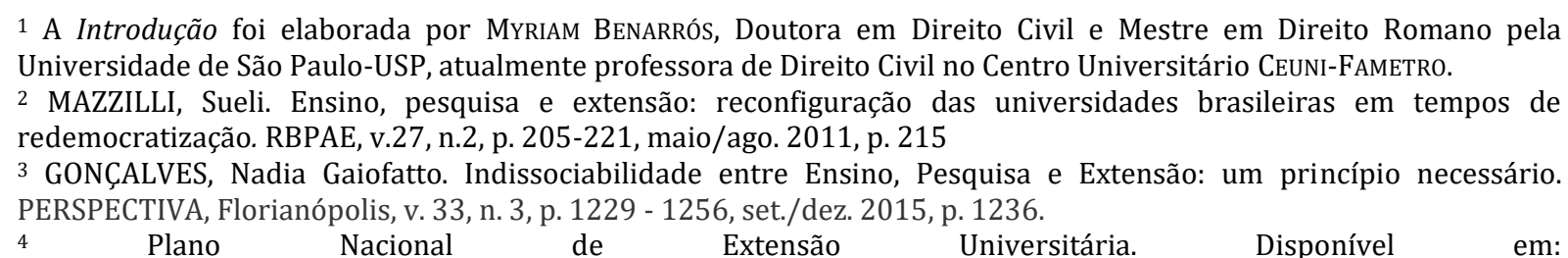

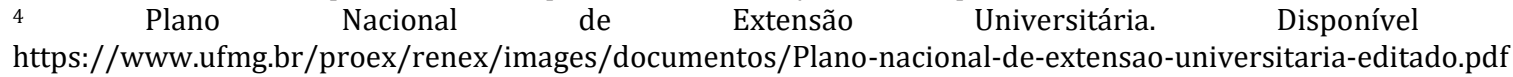
Acesso em 18/11/2019

Cf. GONÇALVES, Nadia Gaiofatto. Indissociabilidade entre Ensino. Op. cit. p. 1237. 
O Projeto de Articulação Entre Pesquisa, Ensino, Extensão e Responsabilidade Social Institucional PAPEERI, que tem como objetivo inserir os discentes desta IES na pesquisa, articulada com o ensino e a extensão, considera a necessidade de executar projetos de pesquisa multidisciplinares, contribuindo, ainda, com a formação de recursos humanos para a pesquisa e o desenvolvimento regional. 0 Projeto busca também despertar no aluno a capacidade de ler a realidade da vida criticamente e ser capaz de intervir nessa realidade construindo e reconstruindo conhecimentos e trocando saberes, a partir de uma relação entre a teoria e a prática no quadro de uma constante interação entre academia e comunidade.

O tema proposto neste PAPEERI está alinhado da seguinte forma:

$$
\begin{aligned}
& \text { - Curso de Graduação: bacharelado em Direito } \\
& \text { - } \quad \text { Área: Ciências Sociais e Jurídicas } \\
& \text { - Linha de extensão: Direitos Humanos, Minorias, Justiça, Cidadania e meio } \\
& \text { ambiente. }
\end{aligned}
$$

Assim o projeto nasce do direito concedido a todo idoso à saúde e à vida, garantidos pela Constituição Federal, pelo Estatuto do Idoso e demais leis extravagantes.

Dessa forma, realizou-se uma pesquisa de campo visando à verificação na Comunidade Antônio Aleixo do acesso efetivo dos idosos à saúde, de modo que se constatasse a eficácia do preceito constitucional contido no artigo 196 que dispõe:

Art. 196. A saúde é direito de todos e dever do Estado, garantido mediante políticas sociais e econômicas que visem à redução do risco de doença e de outros agravos e ao acesso universal e igualitário às ações e serviços para sua promoção, proteção e recuperação.

Destarte, o Estado, nos termos dos artigos 197 e 198 da Constituição Federal, implantará políticas públicas adequadas que possam tornar eficaz o comando contido no artigo 196.

É cediço que a população brasileira está envelhecendo, um reflexo, dentre outros fatores, do aumento da expectativa de vida devido aos avanços que o sistema de saúde vem conquistando. Segundo o Instituto Brasileiro de Geografia e Estatística (IBGE), a população com 60 anos ou mais no País corresponde a 8,6\% da população total (cerca de 14 milhões, dados do Censo de 2000). Projeções demográficas indicam que este número poderá ultrapassar, nos próximos 25 anos, a marca dos 30 milhões. 0 Estatuto do Idoso representa um grande avanço da legislação brasileira iniciado com a promulgação da Constituição de 1988. Elaborado com intensa participação das entidades de defesa dos interesses das pessoas idosas, ampliou em muito a resposta do Estado e da sociedade às suas necessidades. Trata dos mais variados aspectos, abrangendo desde direitos fundamentais até o estabelecimento de penas para os crimes mais comuns cometidos contra essas pessoas. A ação de disseminar as informações sobre os direitos constitucionais é parte integrante da Agenda de Compromisso dos gestores federais, estaduais e municipais do Sistema Único de Saúde (SUS), a qual engloba esforços para mobilização de todos na estratégia de efetivar no País um "Pacto pela Vida"5.

Dentre as muitas conquistas advindas da Constituição Federal, destaca-se a Seguridade Social, um novo sistema de proteção social, constituída por um tripé cujas políticas sociais devem ser destinadas a assegurar os direitos relativos à saúde, à previdência, e à assistência social, através de um conjunto integrado de ações de iniciativa dos poderes públicos e da sociedade, segundo o que é estabelecido no art. 194 da Constituição Federal.

No que diz respeito ao idoso, a partir da Constituição Federal de 1988, essa temática foi ganhando maior destaque, seguindo o que é estabelecido em seu art. 1ำ que entre os fundamentos da República Federativa do Brasil põe a cidadania e a dignidade da pessoa humana, bem como nos arts. 14, 40, 201, 203, 229 e 230 desta constituição, voltados à pessoa idosa. Na década de 70, todo o trabalho realizado com idosos no Brasil era de cunho caritativo, desenvolvido especialmente por ordens religiosas ou entidades leigas filantrópicas.

Apesar da inserção sobre as questões do envelhecimento na Constituição Federal de 1988, somente em 1994 foi instituída uma política nacional voltada especificamente para os Idosos, a Política Nacional do Idoso, Lei n. 8842/94 que tem por objetivo assegurar os direitos sociais do idoso, criando condições para

\footnotetext{
5 Brasil. Ministério da Saúde. Estatuto do Idoso / Ministério da Saúde. 'Introdução'. 2. ed. rev. Brasília: Editora do Ministério da Saúde, 2007. 5-6 pp.
} 
promover sua autonomia, integração e participação efetiva na sociedade, como é estabelecido em seu art. 1o. A Política Nacional do Idoso tem sua base em cinco princípios estabelecidos no art. 3ํo apresentados da seguinte maneira:

I - a família, a sociedade e o estado têm o dever de assegurar ao idoso todos os direitos da cidadania, garantindo sua participação na comunidade, defendendo sua dignidade, bem-estar e o direito à vida;

II - o processo de envelhecimento diz respeito à sociedade em geral, devendo ser objeto de conhecimento e informação para todos;

III - o idoso não deve sofrer discriminação de qualquer natureza;

IV - o idoso deve ser o principal agente e o destinatário das transformações a serem efetivadas através desta política;

$\mathrm{V}$ - as diferenças econômicas, sociais, regionais e, particularmente, as contradições entre o meio rural e o urbano do Brasil deverão ser observadas pelos poderes públicos e pela sociedade em geral, na aplicação desta Lei. (Lei no 8.842/1994)

Vale destacar os incisos I e IV que estabelecem como público alvo desta lei especificamente a pessoa idosa, portanto, todas as ações baseadas nesta lei devem ser em favor do idoso, de forma que busquem a garantia e a efetivação de seus direitos objetivando ao máximo sua manutenção na comunidade, junto de sua família, da forma mais digna e confortável possível fazendo valer o que é estabelecido nesta lei.

A Constituição Federal Brasileira, por outro lado, dispõe em seu artigo 196 que: "a saúde é um direito de todos e dever do Estado, garantindo mediante políticas sociais e econômicas que visem à redução do risco de doença e de outros agravos e ao acesso universal e igualitário às ações e serviços para sua promoção, proteção e recuperação". Já na lei 8.080/90 que regula em todo o território nacional, as ações e serviços de saúde, assegura em seu artigo $2^{\circ}$ : "saúde é um direito fundamental de ser humano, devendo o Estado prover condições indispensáveis no seu pleno exercício".

Destarte, pode-se afirmar que o acesso à saúde pública é, no ordenamento brasileiro, um direito universal consagrado constitucionalmente e por leis infraconstitucionais. No que concerne aos idosos, deve-se salientar a legislação específica em matéria de terceira idade, i.e, o sistema normativo implantado pelo Estatuto do Idoso, Lei 10.741/2003 que em seu capítulo IV trata do direito à saúde; a partir do artigo 15o o estatuto assegura a atenção integral à saúde do idoso devendo o mesmo ser assistido pelo Sistema Único de Saúde - SUS, prioritariamente, tendo o idoso o direito ao acesso universal e igualitário, incluído a atenção especial a saúde e às doenças que afetam preferencialmente os idosos. 0 tema saúde é bastante abordado pelo estatuto conferindo a terceira idade direitos substancialmente relevantes como a gratuidade de medicamentos, especialmente quando diz respeito aos medicamentos de uso continuado, também sendo promovido na forma da lei a gratuidade de próteses, órteses e outros recursos relativos ao tratamento, habilitação e reabilitação.

Entre outros direitos garantidos pelo Estatuto do Idoso está o atendimento domiciliar, sendo incluído a internação no caso de impossibilidade de locomoção ou mesmo para os idosos que necessite deste atendimento, essa assistência também é garantida para os que estão abrigados ou acolhidos, por instituições públicas ou filantrópicas. No seu artigo 16, o legislador assegura o acompanhamento como direito ao idoso internado ou em observação, cabendo ao médico se for o caso justificar por escrito o motivo para a não permanência do acompanhante no ambiente hospitalar. Dentre outros direitos, o Estatuto assegura aos idosos o direito ao plano de saúde impedindo que os mesmos reajustem as mensalidades de acordo com o critério de idade, como podemos verificar no art. $15 \S 3$ o do Estatuto do Idoso onde veda a discriminação do idoso nos planos de saúde pela cobrança de valores diferenciados em razão da idade.

Apesar do Estatuto do Idoso definir como prioridade o atendimento de saúde ao idoso e determinar a implementação de políticas públicas para que isso realmente se efetive, pode-se perceber diante de fatos que ocorrem no cotidiano e os que são publicados pela imprensa, que são constantes as violações aos direitos dos idosos e que ainda estamos muito longe de vermos garantidos os atendimentos necessários a esta população. A impunidade do Estado no descumprimento da lei, e o desconhecimento dos usuários quanto aos seus direitos, sendo cumulado com a pouca cobrança da sociedade aos órgãos de defesa competente parece apontar para um dos motivos desse descaso com a saúde da população. Vale lembrar que a simples existência de leis que proclamem os direitos sociais por si só não conseguem mudar a 
realidade antes é necessário agregar os direitos a uma política social eficaz, que de fato assegurem materialmente os direitos já garantidos ${ }^{6}$.

0 direito à saúde, dentre os direitos sociais, tem merecido maior reflexão pelo expressivo número de ações judiciais que reivindicam medicamentos, insumos e tratamentos médicos em face do Estado, especialmente pelos idosos que tem se valido do Poder Judiciário para coagir a Administração a cumprir o dever que a Constituição e o Estatuto do Idoso impõem. É tão expressiva a quantidade de ações judiciais com esse intuito, que o fato já vem sendo chamado de "Judicialização da Assistência Farmacêutica", "Judicialização da Saúde"7.

Não há dúvida de que o envelhecimento da população se apresenta como um fenômeno de escala mundial, que emerge como um fio condutor, afetando de maneira diferenciada diversos países. Segundo a Organização Mundial de Saúde (OMS) em 2025, o Brasil será o sexto país com o maior percentual de idosos. É mister enfatizar que tal processo revela-se como uma situação preocupante para os governantes brasileiros, em detrimento da vasta demanda de recursos que esta nova condição representa. Na perspectiva dos direitos do idoso, apesar da Constituição Federal de 1988 assegurar vários aspectos que permeiam o acesso à cidadania, ainda se faz necessária a criação de políticas públicas mais eficientes que vislumbrem de maneira holística o contexto do envelhecimento. A Política Nacional do Idoso aprovada pela Lei no 8.842/94 representa um dos marcos na atenção à pessoa idosa, pois, ratifica o dever da família, da sociedade e do Estado diante do idoso e, no âmbito da saúde, garante uma assistência integral nos diversos níveis de atendimento. Posteriormente a esta, através da Portaria no 2.528 de 2006, é criada a Política Nacional de Saúde da Pessoa Idosa com a finalidade de promover o envelhecimento ativo e saudável. Ela reconhece o idoso como um sujeito de direitos, capaz de responder às demandas da vida cotidiana de forma autônoma e independente. Nessa interface, o Estatuto do Idoso, aprovado no ano de 2003, é outro documento que garante os direitos do idoso em saúde, legitimando todos os meios legais para sua efetivação. O Sistema Único de Saúde (SUS) também assegura o direito básico ao ingresso digno do idoso nos serviços de saúde, orientando que a Atenção primária seja a porta de entrada desses usuários. Contudo, apesar dos aparatos já mencionados, constata-se a violação frequente dos direitos do idoso em saúde, em particular, nas instituições que prestam assistência a essa clientela. 0 que se observa é a existência de uma população idosa carente, desinformada, com saúde precária e excluída dos planos de ação governamentais. Destaca-se ainda como problema de extrema relevância, a falta de capacitação dos profissionais de saúde para cuidar dessa população emergente, onde o despreparo, muitas vezes teórico e prático, para atuar em ações que perpassam pela reabilitação e educação em saúde, configura-se como déficits provenientes das próprias academias ${ }^{8}$.

O CEUNI-FAMETRo no cumprimento da sua missão institucional e na efetivação de um constante diálogo com a sociedade, pretende contribuir com a problemática evidenciada no presente projeto. Ademais, devese salientar que as universidades brasileiras têm um sentido de existir, uma razão de ser, e sua práxis pedagógica consubstancia-se no princípio republicano constante no artigo 207 da Constituição Federal de 1988, o qual afirma a indissociabilidade entre as dimensões do ensino, da pesquisa e da extensão. A indissociabilidade entre ensino-pesquisa-extensão possibilita novas formas pedagógicas de reprodução, produção e socialização de conhecimentos, efetivando a interdisciplinaridade. Ela oportuniza também superar a dicotomia entre teoria/prática, sujeito/objeto, empiria/razão, constituindo outro fundamento epistêmico.

Nesse sentido, a existência do presente projeto a ser realizado pelo CEUNI-FAMETRO na comunidade em comento, através do Núcleo de Práticas Jurídicas, auxiliará as famílias na identificação dos idosos que não possuem acesso à saúde, assim como estará contribuindo para a salvaguarda da dignidade desses cidadãos, a partir desta prática, ficará evidenciada a atuação profícua dos tripés que constituem o alicerce do Ceuni-Fametro: Ensino, Pesquisa e Extensão, pautados na Responsabilidade Social, uma vez que a razão de ser e existir das Instituições de Ensino Superior é a construção e transferência de conhecimento para formação acadêmica.

\footnotetext{
6 LEITE, Queila. 0 idoso e 0 seu direito à saúde. Disponível em: https://envelhecerdireito.wordpress.com/2017/05/25/o-idoso-e-seu-direito-a-saude/ Acesso em 17/10/2019.

7 DIAS, Eliotério Fachin. O Estatuto do Idoso e a judicialização do direito à saúde. Disponível em: https://jus.com.br/artigos/20304/o-estatuto-do-idoso-e-a-judicializacao-do-direito-a-saude Acesso em 17/10/2019.
}

${ }^{8}$ MORAES, Janaine C. Oliveira; BRITO, Fabiana Medeiros de; COSTA, Emilie de Oliveira; BARROS, Eveline de Oliveira; COSTA, Iluska Pinto da. O Idoso e seus direitos em Saúde: uma compreensão sobre o tema na realidade atual. Revista Brasileira de Ciências de Saúde, v. 18, n. 3. 256 p. 
A relevância deste projeto se baseia na promoção da pesquisa científica produzida pelo seu corpo acadêmico, construindo o saber local necessário para transformação da comunidade, em uma sociedade sustentável respeitando os princípios éticos e humanísticos. Este projeto direciona para a formação de iniciantes cientistas no CEUNI-FAMETRO, promovendo, por meio da pesquisa, mudanças na qualidade de vida dos moradores da comunidade Vila Amazonas, e da solução de problemas para a redução de desigualdades sociais e exclusão, promovendo a transformação social.

Este projeto por fim, permitiu que o graduando em Direito, desenvolvesse competências, habilidades e atitudes na organização e execução de atividades de pesquisa científica, inovação tecnológica e extensão.

\section{REFERÊNCIAS}

[1] GONÇALVES, Nádia Gaiofatto. Indissociabilidade entre Ensino, Pesquisa e Extensão: um princípio necessário. PERSPECTIVA, Florianópolis, v. 33, n. 3, set./dez. 2015.

[2] MAZZILLI, Sueli. Ensino, pesquisa e extensão: reconfiguração das universidades brasileiras em tempos de redemocratização. RBPAE, v.27, n.2, maio/ago. 2011.

[3] MORAES, Janaine C. Oliveira; BRITO, Fabiana Medeiros de; COSTA, Emilie de Oliveira; BARROS, Eveline de Oliveira; COSTA, Iluska Pinto da. O Idoso e seus direitos em Saúde: uma compreensão sobre o tema na realidade atual. Revista Brasileira de Ciências de Saúde, v. 18, n. 3, 2014.

[4] LEITE, Queila. 0 idoso e o seu direito à saúde

[5] Disponível em: https://envelhecerdireito.wordpress.com/2017/05/25/o-idoso-e-seu-direito-a-saude/ Acesso em 17/10/2019.

[6] DIAS, Eliotério Fachin. 0 Estatuto do Idoso e a judicialização do direito à saúde

[7] Disponível em: https://jus.com.br/artigos/20304/o-estatuto-do-idoso-e-a-judicializacao-do-direito-a-saude Acesso em 17/10/2019. 


\section{Capítulo 1}

\section{Aspectos constitucionais}

Renata da Silva Brito

Analice Cavalcante Pinto

Hávila K. Oliveira de Oliveira

Regina Celly da Costa 
O Direito fundamental à saúde e em especial, a do idoso nem sempre foi considerado um direito fundamental. Assim, nem sempre recebeu proteção legal. É uma questão de exercício da cidadania e da democracia

A história do Direito fundamental à saúde é recente, datando sua proteção pelos ordenamentos legais a nível internacional, que teve inicio a partir do final da Segunda Guerra Mundial (1939 a 1945). Na verdade, até o início do século XX, não falava-se ou tratava-se a questão da saúde como um Direito fundamental, pois estava relacionada ao Direito à vida. Esse Direito inicialmente teve amparo nas Declarações fundamentais como: a Declaração de Virgínia de 1776, a Declaração Francesa de 1789 e outros. Foi exatamente na transição do Estado liberal para o Estado do Bem-estar Social ${ }^{9}$ que iniciou o processo de perspectiva da saúde ser um Direito fundamental. A partir da introdução do fundamento da dignidade da pessoa como um valor, fundamento que passou a ser observada por todos os povos e nações, principalmente com a introdução do artigo 25 da Declaração dos Direitos Humanos ${ }^{10}$.

Esse artigo ao falar na saúde dos povos defende que a saúde deve ser inserida no contexto relacionado às condições do meio ambiente e isso implica em uma íntima relação com o lazer, horas de trabalho, Previdência Social, uma assistência adequada, alimentação, ou seja, a saúde deve estar associada a um meio ambiente que seja favorável.

Ao falar sobre a saúde como Direito fundamental no Brasil, as Constituições de 1824 e a de 1891, respectivamente as Constituições do Império e do início da República, nada trouxeram relacionado à proteção constitucional à saúde e nada em relação aos idosos. Foi com a Constituição de 1934, que pela primeira vez, trouxe à saúde associada ao Direito do Trabalho, ou seja, à saúde estava relacionada ao Direito do trabalhador, em sentido stricto. A Constituição de 1937 avançou apenas em relação ao direito à saúde da criança, trouxe uma proteção normativa, mas nada relevante em relação ao idoso. Foi a Constituição de 1946, que trouxe uma inovação no que tange à saúde relacionada à repartição de competências, cabendo à saúde ser tratada pela União Federal. Na verdade, foi com a Constituição de 1988, que a saúde ganhou papel importante, contorno de Direito fundamental, inserida como um Direito Social.

Daí em diante é marcante a preocupação dos textos legais com saúde. Essa preocupação pode ser facilmente percebida na redação do art. 6 da Constituição Federal, onde está descrito no artigo 6: "São direitos sociais a educação, a saúde, a alimentação, o trabalho, a moradia, o transporte, o lazer, a segurança, a previdência social, a proteção à maternidade e à infância, a assistência aos desamparados, na forma desta Constituição"11.

Vale ressaltar que o presente estudo relativo à tutela dos direitos e garantias fundamentais dos idosos é de necessária importância, isso porque, o crescimento numeroso da população idosa no Brasil fez surgir à necessidade de tutelas específicas para esse grupo populacional, motivado pelas vulnerabilidades sociais existentes.

Desta maneira, compreende-se que, grande parte da camada social idosa recebeu um tratamento hostil perante boa parte da sociedade, uma vez que, há um comportamento coletivo de objeção referente ao encadeamento do envelhecimento, com total obscuridade quanto à reflexão sobre este período tão sensível da vida, resultando em condição de inércia coletiva sobre a fase do envelhecimento. 0 advento da atual Constituição cidadã, a qual abarca o princípio da isonomia, que impõe o direito de todos a serem tratados com respeito e igualdade, bem como, o capítulo da especial referente à proteção aos idosos no

\footnotetext{
${ }^{9}$ No Estado de bem-estar social, é dever do governo garantir aos indivíduos o que se chama, no Brasil, de direitos sociais: condições mínimas nas áreas de saúde, educação, habitação, seguridade social, entre outras. Ademais, em momentos de crise e de desemprego, o Estado deve intervir na economia de forma que se busque a manutenção da renda e do trabalho das pessoas prejudicadas com a situação do país. Disponível em https://www.politize.com.br/estado-de-bem-estar-social-e-estado-liberal-diferenca/ Acesso em 11 agosto 2020.

10 No livro Estudos de Direito Internacional - Volume XIV - Anais do 6o Congresso Brasileiro de Direito Internacional 2008, o organizador Wagner Menezes, traz uma reflexão a respeito da saúde está entre os direitos humanos, pois é decorrência do próprio direito à vida. Na Declaração Universal de 1948 seu reconhecimento como direito humano era indireto, especialmente no art. 25. Toda pessoa tem direito a um padrão de vida capaz de assegurar a si e a sua família saúde e bem-estar, inclusive alimentação, vestuário, habitação, cuidados médicos e os serviços sociais indispensáveis, o direito à segurança, em caso de desemprego, doença, invalidez, viuvez, velhice ou outros casos de perda dos meios de subsistência em circunstâncias fora do controle (MENEZES, Wagner. Ordem global e transnormalidade. Ijuí: Nijuí, 2005, p. 57).
11
Constituição
Federal
(1988).
Disponível

em:
}

https://www.senado.leg.br/atividade/const/con1988/con1988_07.05.2020/art_6_asp Acesso em 01 nov. 2019. 
teor do art. 230 da Constituição Federal ${ }^{12}$, que possibilitou a criação de outros dispositivos infraconstitucionais, como por exemplo, o Estatuto do Idoso, Lei n.o $10.741^{13}$, em 2003, criado com o intuito de proteção e manutenção de qualidade de vida aos idosos, proporcionaram precipuamente a inauguração de um novo posicionamento com relação ao idoso que deve ser reinserido na nossa sociedade de forma igualitária.

Portanto, é notório que ao longo dos anos, houve inúmeros movimentos sociais que tiveram a união de vários setores do Estado e de suas representações, os quais promoveram a criação de projetos sociais que buscam até hoje um envelhecimento ativo, digno e participativo. Neste ínterim, é passível a análise de que não só os 31 (trinta e um) anos de institucionalização da Constituição Federal de 1988, como a criação de outras legislações voltadas à proteção do idoso, reconheceram em seu contexto democrático os direitos da pessoa idosa enquanto sujeito de direito, ao amparo das necessidades, à dignidade, à velhice, à proteção, renda previdenciária ou assistencial e à atenção à saúde, dentre outras garantias e prerrogativas que devem ser fornecidas pelo Estado democrático de Direito.

Conforme o que foi dito inicialmente sobre o idoso, é importante fazer um estudo no ramo do Direito Constitucional quanto a Aplicabilidade e Eficácia das Normas Constitucionais, para utilizando o método e hermenêutica, possamos interpretar os julgados acerca da área estudada. Sendo que o objetivo dessa publicação é contribuir para as discussões sobre o futuro do Direito a saúde e em especial, a do idoso como Direito fundamental como um dos temas jurídicos relevantes do século XXI.

Delimitaremos a eficácia das normas de acordo com a doutrina estrangeira e doutrina nacional. Onde temos:

\section{DOUTRINA ESTRANGEIRA}

1 - Teoria de Thomas Cooley - Self-executing e Not self-executing ${ }^{15}$.

A norma constitucional Self-executing quando possui todos os meios para aplicabilidade. Já Not selfexecuting não possui meios suficientes para sua aplicação.

2 - Teoria de Vezio Crisafulli - Immediatamente precettive ${ }^{16}$. Segundo o autor as normas, todas elas, são "immediatamente precettive".

\section{DOUTRINA NACIONAL}

1- Doutrina Nacional Manoel Gonçalves Ferreira Filho - normas exequíveis e não exequíveis ${ }^{17}$. As normas exequíveis são aquelas que não dependem de complementação, são completas. As normas não exequíveis são as incompletas que precisam de complementação da doutrina, dividindo essas em normas programáticas, normas de estruturação e normas condicionadas.

São normas programáticas todas que predizem políticas públicas, com aplicabilidade dependendo de legislação específica.

As normas de estruturação são aquelas que criam entes e órgãos.

12 Constituição Federal, Texto constitucional promulgado em 5 de outubro de 1988, com as alterações determinadas pelas Emendas Constitucionais de Revisão nos 1 a 6/94, pelas Emendas Constitucionais nos 1/92 a 91/2016 e pelo Decreto Legislativo no 186/2008, Disponível em: https://www2.senado.leg.br/bdsf/bitstream/handle/id/518231/CF88_Livro_EC91_2016.pdf Acesso em: 01 nov. 2019.

13 Dispõe sobre o Estatuto do Idoso e dá outras providências. Disponível em: http://www.planalto.gov.br/ccivil_03/leis/2003/l10. 741. Htm Acesso em: 01 nov. 2019.

${ }^{14}$ Artigo $230^{\circ}$ da Constituição Federal, com redação dada pela Emenda Constitucional n ${ }^{\circ} 65$ de 2010, dispõe sobre a ordem social envolvendo família, criança, adolescente idoso. BRASIL, Constituição Federal, edição compilada.

Disponível em: http://www.planalto.gov.br/ccivil_03/constituicao/constituicaocompilado.htm Acesso em: 01 nov. 2019.

15 COOLEY, Thomas M. A Treatise on the Constitutional Limitations. Boston: Little, Brown, and Company, 1890 , p. 98.

16 CRISAFULLI, Vezio. La Costituzione e le sue Disposizioni di Principio. Milano: Giuffrè, 1952 (I Quaderni della Costituzione), p.104.

${ }^{17}$ FERREIRA FILHO. Manoel Gonçalves. Curso de Direito Constitucional. 31. ed. São Paulo: Saraiva, 2005, p. 387-388. 
E as normas condicionadas poderiam em tese ser autoexecutáveis, porém, por expresso mandamento constitucional essas acabam dependendo de lei infraconstitucional.

Analisando a jurisprudência pátria, vejamos:

CONSTITUCIONAL. DIREITO À SAÚDE. PROTEÇÃO AOS IDOSOS. AÇÃO PARA APLICAÇÃO DE MEDIDA PROTETIVA. ABRIGO EM ENTIDADE DE ATENDIMENTO. RESPONSABILIDADE SOLIDÁRIA DE TODOS OS ENTES DA FEDERAÇÃO. ARTIGOS 6으, 23, II, 196, CAPUT, E 230, CONSTITUIÇÃO FEDERAL. ARTIGOS $2 \stackrel{\circ}{\circ}, 3 \circ$, CAPUT, 15, E 45, ESTATUTO DO IDOSO (TJRS - ApCiv 70076747237 - 21. a Câmara Cível - j. 21/3/2018 - julgado por Armínio José Abreu Lima da Rosa) ${ }^{18}$.

DIREITO CONSTITUCIONAL - REEXAME NECESSÁRIO//APELAÇ̃̃O CÍVEL AÇÃO CIVIL PÚBLICA - DIREITO À SAÚDE - PESSOA IDOSA - LEGITIMIDADE DO MINISTÉRIO PÚBLICO - FORNECIMENTO DE MEDICAMENTO - LEI FEDERAL N. 10.741/03 - PROTEÇÃO INTEGRAL E ESPECIALIZADA - PROCEDÊNCIA DO PEDIDO. (TJMG - Processo 1.0209.11.002676-9/001 - 5.a Câmara Cível - j. 18/12/2014 - julgado por Saulo Versiani Penna) ${ }^{19}$.

APELAÇÃO CÍVEL. DIREITO À SAÚDE. ABRIGAMENTO DE IDOSO EM INSTITUIÇÃO DE LONGA PERMANÊNCIA. DEVER CONSTITUCIONAL. RESPONSABILIDADE SOLIDÁRIA DA UNIÃO, DOS ESTADOS E DOS MUNICÍPIOS. ESTATUTO DO IDOSO. (TJRS - Ap e Reexame 70066090499 - 21. a Câmara Cível j. 30/9/2015 - julgado por Marco Aurélio Heinz) ${ }^{20}$.

De acordo com firme orientação do Supremo Tribunal Federal e do Superior Tribunal de Justiça, o direito à saúde é dever do Estado, "lato sensu considerado, a ser garantido modo indistinto por todos os entes da federação - União, Estados, Distrito Federal e Municípios, forte nos artigos 6o, 23, II e 196, caput, da Constituição Federal"21.

Dever de proteção integral ao idoso que vem reforçado no artigo 230 da Constituição Federal22 e nos artigos 2ㅇ, 3o caput, 15 e 45, do Estatuto do Idoso ${ }^{23}$ - Lei no 10.741/03, justificando, assim, imposição a todos os entes quanto à complementação ao custeio do abrigo em entidade de atendimento do idoso, fornecimento de medicamentos e abrigo em instituições de longa permanência, conforme demonstrado na jurisprudência acima exposta.

Aplicabilidade das normas constitucionais na abordagem de José Afonso da Silva ${ }^{24}$ como também a contribuição de Meirelles Teixeira ${ }^{25}$ norteiam a reflexão, e sua relação face ao direito à saúde do idoso.

Nesse passo, mister visar a contribuição do professor J. H. Meirelles Teixeira ${ }^{26}$, constitucionalista que foi pioneiro, no Brasil, a burilar as ideias clássicas acerca das normas constitucionais. Em seu ensaio, delineou o conceito de aplicabilidade ${ }^{27}$. Já o jurista José Afonso da Silva ${ }^{28}$ restou por aprimorar a análise de

\footnotetext{
${ }^{18}$ REVISTA DOS TRIBUNAIS. Disponível em: Tribunal de Justiça do Estado do Rio Grande do Sul. Conteúdo Exclusivo WEB | JRP $\backslash 2018 \backslash 231422$. Acesso em: 27 jul. 2019.

${ }^{19}$ REVISTA DOS TRIBUNAIS. Disponível em: Tribunal de Justiça do Estado de Minas Gerais. Conteúdo Exclusivo WEB | Jan / 2015 | JRP $\backslash 2014 \backslash 244931$. Acesso em: 27 jul. 2019.

${ }^{20}$ REVISTA DOS TRIBUNAIS. Disponível em: Tribunal de Justiça do Estado do Rio Grande do Sul. Conteúdo Exclusivo WEB | JRP \2015\423925. Acesso em: 27 jul. 2019.

21 Constituição $\quad$ Federal 1988). Disponível em: https://www.senado.leg.br/atividade/const/con1988/con1988_07.05.2020/art_6_asp Acesso em 01 nov. 2019.

22 Idem.

${ }^{23}$ BRASIL. Estatuto do idoso: lei federal no 10.741, de 01 de outubro de 2003.

24 SILVA, José Afonso da. Aplicabilidade das Normas Constitucionais. 7. ed. São Paulo: Malheiros, 2008.

25 TEIXEIRA. José Horácio Meirelles. Curso de Direito Constitucional. 1aㅡ ed. - Rio de Janeiro: Forense Universitária, 1991.

26 Idem.

27 Designa-se por aplicabilidade, ou eficácia da norma a qualidade de produzir, em maior ou menor grau, efeitos jurídicos, ao regular desde logo, em maior ou menor escala, as situações, relações e comportamentos de que cogita.

${ }^{28}$ SILVA, José Afonso da. Aplicabilidade das Normas Constitucionais. 7. ed. São Paulo: Malheiros, 2008.
} 
Meirelles Teixeira ${ }^{29}$ e, acerca do tema, classificou a normas constitucionais, quanto a sua aplicabilidade em normas de eficácia plena, eficácia contida e, por derradeiro, eficácia.

Tomando como parâmetro tais apontamentos, o presente artigo visa explanar a evolução dos direitos e prerrogativas do idoso no âmbito constitucional e em compatibilidade com o Estatuto do Idoso. Segundo o tal Estatuto, destinado a regular os direitos assegurados às pessoas com idade igual ou superior a 60 (sessenta) anos.

Segundo Silva:

Na primeira categoria incluem-se todas as normas que desde a entrada em vigor da constituição, produzem efeitos essenciais (ou têm a possibilidade de produzi-los), 0 segundo grupo também se constitui de norma que incidem imediatamente e produzem (ou podem produzir) todos os efeitos queridos, mas preveem meios ou conceitos que permitem manter sua eficácia contida em certos limites, dadas certas circunstâncias. Ao contrário as normas do terceiro grupo são todas as que não produzem, com a simples entrada em vigor, todos os efeitos essenciais porque o legislador constituinte, por qualquer motivo, não estabeleceu, sobre a matéria, uma normatividade para isso bastante, deixando esta tarefa ao legislador ordinário ou outro do Estado ${ }^{30}$.

Ainda segundo Silva ${ }^{31}$, era inequívoco a ideia de que todas as normas possuíam eficácia e juridicidade, de forma que poderiam ser diferenciadas quanto ao grau dos efeitos jurídicos e não quanto à sua normatividade.

Depreende-se que a conceituação de Silva ${ }^{32}$ foi forjada da acurada crítica à percepção do jurista italiano Vezio Crisafulli ${ }^{33}$. Em sua compreensão, Crisafulli ${ }^{34}$ define norma programática como uma diretiva ao legislador, uma via a seguir com liberdade respeitando o preceito constitucional, mas sem estar necessariamente, adstrito à Constituição. Para este teórico, existe uma divisão pragmática em que as normas podem ser compreendidas: normas imediatamente preceptivas ou constitutivas, normas de eficácia diferida e, por fim, normas programáticas, empregando objetivos a serem cumpridos futuramente pelo Estado.

Essa classificação e sua terminologia são falsas e inaceitáveis, pela própria improcedência das premissas em que assentam, pois fundamentam-se na distinção entre normas constitucionais jurídicas e não-jurídicas, que já criticamos. Normas puramente diretivas não existem nas constituições contemporâneas. Em sentido geral, já demonstramos, com base na melhor doutrina, que todas as normas jurídicas são dotadas de imperatividade, mesmo as permissivas [...] as chamadas normas programáticas, tidas pela doutrina supra como diretivas e ineficazes, exercem relevante função na ordenação jurídica do país e têm efeitos jurídicos de suma importância, não se dirigindo só aos legisladores, como não raro se afirma ${ }^{35}$.

Com efeito, as normas programáticas já possuem eficácias em si mesmas, exercem relevante função na ordenação jurídica do país e têm efeitos jurídicos de suma importância, não, somente, dirigindo-se aos legisladores, embora caiba ao legislador infraconstitucional, estabelecer regulamentação para o exercício do direito ora garantido. Como exemplo de eficácia reduzida, tem-se o artigo 196 da CRFB (Constituição da República Federativa do Brasil):

Art. 196. A saúde é direito de todos e dever do Estado, garantido mediante políticas sociais e econômicas que visem à redução do risco de doença e de outros agravos e ao acesso universal e igualitário às ações e serviços para sua

\footnotetext{
${ }^{29}$ TEIXEIRA. José Horácio Meirelles. Curso de Direito Constitucional. 1a ed. - Rio de Janeiro: Forense Universitária, 1991.

30 SILVA, José Afonso da. Aplicabilidade das Normas Constitucionais. 7. ed. São Paulo: Malheiros, 2008, p. 82

31 Idem.

32 Idem.

33 CRISAFULLI, Vezio. La Costituzione e le sue Disposizioni di Principio. Milano: Giuffrè, 1952 (I Quaderni della Costituzione).

34 Idem.

35 Idem, p. 81.
} 
promoção, proteção e recuperação ${ }^{36}$.

Certo é que, estando no bojo constitucional, o direito à saúde, como acima mencionamos, torna-se um exemplo útil de norma de eficácia limitada ou reduzida e, visto que embora esteja salvaguardado no texto constitucional, ainda carece de normas regulamentadoras, por tratar-se de questão ético-social, devendo estabelecer, de fato, verdadeiros programas de ação social para que sua concretude alcance todos igualmente.

É a respeito do dispositivo anteriormente empregado que, na atualidade, alguns operadores do direito vêm compreendendo que, o Estado, com lastro no princípio da dignidade da pessoa humana, concebeu o Diploma Constitucional como instrumento de evolução, haja vista, à coroação dos direitos fundamentais sociais. Da mesma forma, Clenio Schulze, juiz federal em Porto Alegre, interpreta o texto do art. 196 da CRFB/1988 como uma leitura adequada do princípio da universalidade da jurisdição, descrito no artigo 5o, XXXV, da Constituição Federal. Para o magistrado, a Magna Carta deixa, assim, de ser distante e estática para ser interpretada como instrumento pautado pelos princípios norteadores da teoria dos direitos sociais:

É verdade que não cabe ao órgão jurisdicional a definição e a criação de políticas públicas de saúde, podendo determinar o cumprimento das medidas já fixadas pela administração em geral, aceitas pela sociedade e, essencialmente, contempladas no corpo da Constituição. [...] Cabe ao magistrado, quando incitado, verificar se há abusividade negativa decorrente da inércia na implementação do direito à saúde, já que existe o dever estatal de estabelecer um standard mínimo a fim de satisfazer as normas constitucionais. Nesse contexto, na ação em que se postula o fornecimento de medicamento, tratamento ou terapia, exige-se do juiz a verificação do cumprimento daquele padrão mínimo, que preconiza a preservação da vida humana ${ }^{37}$.

Tal compreensão se molda e asseverado por José Afonso da Silva:

São prestações positivas proporcionadas pelo Estado direta ou indiretamente, enunciadas em normas constitucionais, que possibilitam melhores condições de vida aos mais fracos, direitos que tendem a realizar a igualização de situações sociais desiguais. São, portanto, direitos que se ligam ao direito de igualdade ${ }^{38}$.

Preocupando-se detidamente com a pessoa idosa, este hipervulnerável, no contexto social, que o legislador infraconstitucional está impelido, pela carta política, a regulamentar como e com quais auxílios o direito à saúde será efetivado.

Cotejamos o seguinte julgado:

\begin{abstract}
MANDADO DE INJUNÇÃO. ALEGADA AUSÊNCIA DE NORMA REGULAMENTADORA DO ART. 40, § 4으, DA CONSTITUIÇÃO DA REPÚBLICA. INFORMAÇÕES. VISTA AO PROCURADOR-GERAL DA REPÚBLICA. Relatório 1. Mandado de injunção impetrado por Jorge Gonçalves da Silva, em 2.6.2016, contra pretensa omissão legislativa imputada ao Presidente da República em regulamentar o art. 40, § 4⿳o’, inc. I, da Constituição da República. 2.0 Impetrante afirma-se portador de deficiência visual e "servidor do Tribunal de Justiça do Estado do Rio de Janeiro, com 28 anos de serviço público, lotado atualmente na 1 a Vara da Infância e Juventude e do Idoso" (fl. 1, doc. 1). Sustenta que, "em razão de sua deficiência, tem direito a aposentadoria especial, com a adoção dos requisitos e critérios diferenciados, em conformidade com a CR, art. 40, § 4⿳⺈, I, alterado pela Emenda Constitucional n. 47, de 05 de julho de 2005" (fl. 1, doc. 1). Pede o benefício da justiça gratuita, prioridade na tramitação desta ação e "seja concedida aposentadoria especial ao autor, determinando a aplicação ao caso do disposto na Lei Complementar 142/2013, dando ciência da decisão ao Tribunal de Justiça do Estado do Rio de Janeiro" (fl. 6, doc. 1). 3. 0 Impetrante
\end{abstract}

\footnotetext{
36 Constituição da República Federativa do Brasil. Brasília, 1988. Disponível em: http://www.planalto.gov.br/ccivil_03/Constituição/ConstituicaoCompilado.htm. Acesso em 20 nov. 2019.

37 SCHULZE, Clenio Jair. A judicialização da saúde e o Conselho Nacional de Justiça. Disponível em: https://revistadoutrina.trf4.jus.br/index.htm?https://revistadoutrina.trf4.jus.br/artigos/edicao058/Clenio_Schulze.h tml Acesso 12 nov. 2019.

38 SILVA, José Afonso da. Aplicabilidade das Normas Constitucionais. 7. ed. São Paulo: Malheiros, 2008, p. $286-287$.
} 
comprovou ter a Administração Pública indeferido requerimento de aposentadoria com fundamento na ausência da norma regulamentadora do art. 40, § 4ํㅡ, inc. I, da Constituição da República (doc. 2). Examinados os elementos havidos nos autos, DECIDO. 4 . 0 mandado de injunção é garantia constitucional prestante, exclusivamente, a viabilizar direitos ou liberdades constitucionais, a soberania, a cidadania e a nacionalidade, quando não puderem ser exercidos por ausência de norma regulamentadora (art. 5º, inc. LXXI, da Constituição da República). Pressupõe, portanto, a existência de preceito constitucional dependente da regulamentação por regra de categoria inferior na hierarquia dos tipos normativos. 5 . Na espécie vertente, o Impetrante alega que a ausência da norma regulamentadora do art. 40, § 4ํㅡㄴ, inc. I, da Constituição da República tornaria inviável o exercício do seu direito à aposentadoria especial, pois os termos para sua aposentação deveriam ser definidos por lei complementar. 6 . Defiro os pedidos de justiça gratuita e de prioridade na tramitação desta ação (art. 62 do Regimento Interno do Supremo Tribunal Federal e art. 1.048, inc. I, do Código de Processo Civil). 7. Notifique-se o Impetrado para, querendo, prestar informações no prazo de dez dias (art. 203 do Regimento Interno do Supremo Tribunal Federal). 8. Na sequência, vista ao Procurador-Geral da República (arts. 52, inc. IX, e 205 do Regimento Interno do Supremo Tribunal Federal e art. 103, § 1o, da Constituição da República). (grifo nosso) (STF - MI: 6604 DF - DISTRITO FEDERAL 4001251-37.2016.1.00.0000, Relator: Min. CÁRMEN LÚCIA, Data de Julgamento: 27/06/2016, Data de Publicação: DJe $13701 / 07 / 2016)^{39}$.

Destarte, entendendo que o Estado é garantidor dos direitos do idoso é que firma-se a necessidade de acionar o Poder Público, seja por meio da prestação jurisdicional ou, ainda, para que este idealize políticas, programas e legislação que assegurem as garantias e direitos, de maneira a efetivar o previsto na Constituição, além da correta positivação das tutelas que se comprometeu a conceder e salvaguardar.

Assim conclui-se que o artigo 196 da Constituição Federal é uma norma de eficácia imediata, ou seja, independe de norma infraconstitucional e para efetivar o direito subjetivo material referente à saúde, daí a importância em relacionar esse direito e em especial ao idoso com as demais disciplinas e princípios do Direito.

Para efetividade do Direito fundamental à Direito saúde, que participou das três gerações dos Direitos fundamentais, os primeiros anos e séculos foram voltados para à defesa dos Direitos de primeira geração, as liberdades negativas, defendendo o não-fazer Estatal. A saúde é analisada no seu contexto coletivo e em defesa da justiça social.

Sendo que o início do século XX marcou os Direitos fundamentais, os Direitos sociais, como também o Direito à saúde. Surgiu um binômio em relação à sua efetividade, na medida, em que ficou explícito que as necessidades humanas são infinitas, mas os recursos orçamentários são limitados dentro do Constitucionalismo. Portanto, no Direito fundamental à saúde, ainda há uma visão patrimonialista desde a sua origem. Inserido no rol dos Direitos sociais desde seu início, esses direitos foram considerados, como políticas que dependeriam exclusivamente da atuação do Estado, seja no pólo passivo ou ativo, além de serem confundidos como políticas públicas que necessitavam da prestação estatal para sua eficácia. 0 artigo 200 da Constituição Federal de 1988 fala no sistema único de saúde juntamente com as leis $8080 / 90^{40}$ e lei $8.142 / 90^{41}$ que vieram implementar as formas de fiscalização em cumprimento ao Direito à saúde. Isso significa que a cada quatro anos deverá haver conferências, avaliação sobre a efetividade da Política Nacional de Saúde para avaliar novos casos de doenças, políticas de prevenção e repressão, ou seja, nortear as diretrizes para que haja um ajuste, esteja realmente afinado junto ao Conselho da Saúde e assim alcançar sua máxima efetividade, seja no contexto geral ou,e em especial em relação aos idosos.

\footnotetext{
${ }^{39}$ SUPREMO TRIBUNAL FEDERAL. Disponível em: https://stf.jusbrasil.com.br/jurisprudencia/356997227/mandadode-injuncao-mi-6604-df-distrito-federal-4001251-3720161000000 Acesso 27 jul. 2019.

40 Disponível em: http://www.planalto.gov.br/ccivil_03/leis/l8080.htm Acesso em 9 de agosto de 2020.

${ }^{41}$ Disponível em: http://www.planalto.gov.br/ccivil_03/leis/L8142.htm Acesso em 9 de agosto de 2020.
} 


\section{REFERÊNCIAS}

[1] BRASIL. Constituição (1988). Constituição da República Federativa do Brasil. Brasília: Senado, 1988.

[2] COOLEY, Thomas M. A Treatise on the Constitutional Limitations. Boston: Little, Brown, and Company, 1890

[3] CRISAFULLI, Vezio. La Costituzione e le sue Disposizioni di Principio. Milano: Giuffrè, 1952 (I Quaderni della Costituzione).

[4] FERREIRA FILHO. Manoel Gonçalves. Curso de Direito Constitucional. 31. ed. São Paulo: Saraiva, 2005.

[5] FRIEDE, Reis. Ciência Política e Teoria Geral do Estado. 1.ed. Rio de Janeiro: Forense, 2002.

[6] MENEZES, Wagner (org.) Anais do 6o Congresso Brasileiro de Direito Internacional -Volume XIV. Curitiba: Editora Juruá, 2008.

[7] _. Ordem global e transnormalidade. Ijuí: Nijuí, 2005.

[8] SCHULZE, Clenio Jair. A judicialização da saúde e o Conselho Nacional de Justiça. Revista de Doutrina da $4^{\mathrm{a}}$ Região, Porto Alegre, n. 58, fev. $2014 . \quad$ Disponível em: https://revistadoutrina.trf4.jus.br/index.htm?https://revistadoutrina.trf4.jus.br/artigos/edicao058/Clenio_Schulze.h tml

[9] SILVA, José Afonso da. Aplicabilidade das Normas Constitucionais. 7. ed. São

[10] Paulo: Malheiros, 2008.

[11] TEIXEIRA. José Horácio Meirelles. Curso de Direito Constitucional. 1aa ed. - Rio de Janeiro: Forense Universitária, 1991. 


\section{Capítulo 2}

\section{Aspectos civis e internacionais}

Myriam Benarrós

Tayana Souza da Silva

Yanca N. Ribeiro de Oliveira 


\section{PRELIMINARES}

Na China Antiga, o pensamento de Confúcio (551-479 a.C.) tinha como base a família, no âmbito da sociedade familiar todos os membros deviam obediência ao sujeito masculino mais velho, e até mesmo a mulher, que via de regra estava submetida ao poder do homem, na velhice passava a ter um poder mais elevado do que o dos jovens masculinos. Confúcio defendia a ideia de que a autoridade na velhice se justifica pela aquisição da sabedoria. Para Confúcio não há nada no mundo de tão grande como o ser humano e no ser humano nada é maior do que a piedade filial. Acreditava o filosofo chinês que aos 60 anos o ser humano compreende, sem necessidade de refletir, tudo o que ouve, bem como ao completar 70 anos, pode ele seguir os desejos do seu coração sem transgredir regra nenhuma, destarte, almejava ele que os idosos pudessem viver em paz e, principalmente, que os mais jovens amassem esses seres. ${ }^{42}$

0 advento da filosofia na Grécia marca o fim do pensamento místico e o começo do pensamento racional que acarreta o surgimento de uma forma de pensamento e sistema de explicação sem analogia no mito. Os gregos amaram a beleza em todas as suas formas, sendo, portanto, amantes do corpo jovem e saudável, cultuando-o e preservando-o; a velhice, de modo geral, era tratada com desdém, muito pouco considerada e até motivo de pavor, principalmente pela perda dos prazeres proporcionados pelos sentidos. Contudo, havia aqueles que opinavam diversamente no que concernia ao tema da velhice, Homero, por exemplo, associava a velhice à sabedoria. Já para Sólon, os prazeres contavam menos que a aquisição da sabedoria ${ }^{43}$.

Embora a influência da cultura grega na cultura romana seja notória e incontestável a estrutura da sociedade romana dava uma grande importância aos velhos, pois, eram considerados os maiores, ou seja, aqueles que possuíam a sabedoria e experiência necessária para conduzir a Res Publica. No mundo romano os mores maiorum, os costumes dos antigos, regulavam todos os aspectos da vida citadina, representando por longo tempo a única fonte do direito. Na sociedade romana os jovens deviam obediência ao pater familias, que, via de regra, era o indivíduo mais velho de uma determinada sociedade familiar, sendo ele o guardião das memórias dos antepassados. A figura do senex era muito importante na sociedade romana, a tal ponto que os romanos criaram uma assembleia de anciãos, o Senatus, para auxiliar o rei.

Marcos Túlio Cícero, no ano 44 a.C., escreve um pequeno tratado, o De Senectude, que aborda o tema da velhice, dando a Catão, o Censor, a tarefa de explicar a Cipião Emiliano e Caio Lélio o que seja a velhice e como ela pode ser digna de ser vivida. Cícero através da análise de diversas figuras da História Romana exalta a sabedoria e as riquezas internas do indivíduo na idade avançada, as alegrias do espírito em contraposição à decadência do corpo. 0 tratado se conclui com as considerações ciceronianas sobre a imortalidade da alma e a serena espera pela morte ${ }^{44}$.

\section{ENVELHECIMENTO GLOBAL}

O envelhecimento populacional apresenta grandes desafios a serem enfrentados; estima-se que no mundo a proporção de pessoas com 60 anos ou mais cresce de forma mais rápida do que a de outras faixas etárias. Em 2050, prevê-se que se terá dois bilhões de idosos, 80\% deles nos países em desenvolvimento. Observe-se, ainda, que a população de 80 anos ou mais é a que mais cresce e poderá ultrapassar os atuais 11\% para 19\% em 2050. Longevidade, porém, não significa envelhecer com qualidade de vida e saudável; com o aumento da expectativa de vida, verifica-se, também, um aumento das doenças crônicodegenerativas. 0 crescimento da população idosa vem ocorrendo no Brasil desde a década dos anos 60 . Observe-se, ainda, que a família brasileira com a modernização tem se modificado; a inserção das mulheres no mercado do trabalho, assim como o uso dos contraceptivos, tem reduzido o tamanho das famílias e a falta de tempo no ritmo de vida moderno vêm modificando a relação de cuidado para com os membros idosos da comunidade familiar. A tudo isso se deve acrescentar a escassez de alternativas para as famílias manterem seus idosos em casa, além dos idosos abandonados terem aumentado a demanda por internações ${ }^{45}$.

${ }^{42}$ SANTOS, Silvana Sidney Costa. Envelhecimento: visão de filósofos da antiguidade oriental e ocidental. Revista Rene. Fortaleza, 2001, p. 91.

${ }^{43}$ Ibidem; cf. FEIJÓ, Maria das Candeias Carvalho; MEDEIROS, Suzana da A. Rocha.A Sociedade Histórica dos Velhos e a Conquista de Direitos. Revista Kairós Gerontologia. São Paulo, 2011, p. 111-113.

44 Cícero. Cato maior, de senectude. Trad. ital. Luigi Chiosi. Disponível em: http://giggino47.xoom.it/Cato\%20maior\%20de\%20senectute.pdf . Acesso 20 julho 2020

${ }^{45}$ POLLO, Sandra Helena Lima; ASSIS, Mônica de. Instituições de longa permanência para idosos - ILPIS: desafios e alternativas no município do Rio de Janeiro. Rev. bras. geriatr. gerontol., Rio de Janeiro ,v. 11, n. 1, p. 30, Apr. 2008. 
O surgimento de instituições para idosos é bastante antiga e o cristianismo foi pioneiro no amparar os velhos, o primeiro asilo, segundo a tradição, foi fundado por Papa Pelágio II (520-590) que transformou a própria casa em um asilo para velhos. Entende-se por asilo, instituição antiquíssima, uma casa de assistência social onde são acolhidas pessoas pobres e desamparadas, como mendigos, crianças abandonadas, órfãos e velhos ${ }^{46}$.

Não há dúvida que muitos seres humanos de idade avançada aceitam a velhice e tentam adaptar-se aos limites impostos pela decadência do corpo. Na atualidade, embora muitos idosos não se sintam felizes pelos anos vividos, tentam aproveitar os últimos anos de vida, engajando-se nos programas oferecidos pela universidade aberta à terceira idade, nas aulas de ginásticas a eles direcionadas, frequentando os clubes ou associações dedicadas ao lazer e ao entretenimento, e que desenvolvem atividades que possam despertar o interesse no aprendizado de novas situações, como tocar um instrumento, usar o computador e outras. É necessário estimular nos seres humanos idosos a vontade de viver intensamente e com melhor qualidade possível a sua última fase de vida ${ }^{47}$. Por outro lado, a inserção do idoso na sociedade se torna cada vez mais difícil porque se na antiguidade a velhice era considerada uma fase em que o indivíduo adquiria a sabedoria e, portanto, o senex era respeitado e valorizado, hoje, infelizmente, não é assim que a sociedade vê o idoso, pois, atualmente essas pessoas são desvalorizadas e, muitas vezes, consideradas um ônus para a sociedade, um peso para a família.

$\mathrm{Na}$ atualidade, a velhice continua sendo odiada e pouco protegida, ainda que tenhamos uma legislação que visa amparar o idoso. A Organização das Nações Unidas (WHO, 2002) no seu Relatório Mundial sobre a Violência e a Saúde da pessoa idosa relatou que, segundo pesquisas realizadas, 5\% da população idosa mundial é vítima de abuso em seu lar. Ademais, é notório que a maioria dos casos de violência e situação de risco contra idosos não são notificados aos órgãos responsáveis pela defesa dos direitos da pessoa idosa, o que naturalmente dificulta o mapeamento dos agressores. A subnotificação sugere que, provavelmente, pelo fato da família ser o lugar principal onde ocorrem os atos de violência, de negligências e de abusos contra os velhos, a existência de um pacto silencioso. A discussão sobre a violência cometida contra a pessoa idosa em suas diferentes formas é um tema que consta na agenda de preocupações internacionais e nacionais. Essa problemática deve ser inserida no campo dos direitos humanos e da cidadania, devendo tornar-se alvo de atenção de governantes e de organismos internacionais e supranacionais ${ }^{48}$.

A Organização das Nações Unidas alerta que o mundo está no centro de uma transição do processo demográfico única e irreversível que resultará no aumento da população idosa no mundo todo, pois, à medida que as taxas de fertilidade diminuem, a proporção de pessoas com 60 anos ou mais deve duplicar até 2050, alcançando dois bilhões em 2050. Na maioria dos países, o número de pessoas acima dos 80 anos deve quadruplicar para quase 400 milhões até lá. A população com 60 anos ou mais está crescendo a uma taxa de cerca 3\% por ano. Globalmente, a população com 60 anos ou mais está crescendo mais rápido que todos os grupos etários mais jovens. Atualmente, a Europa tem a maior porcentagem de população com 60 anos ou mais (25\%).

Nesse diapasão, a primeira Assembleia Mundial sobre o Envelhecimento foi convocada pela ONU em 1982, que elaborou o Plano de Ação Internacional de Viena sobre o Envelhecimento, com 62 pontos. Este aborda temas como como saúde e nutrição, proteção de consumidores idosos, habitação e meio ambiente, família, bem-estar social, segurança de renda e emprego, educação e a coleta e análise de dados de pesquisa. A preocupação do programa das Nações Unidas para o envelhecimento é a facilitação e a promoção das três vertentes prioritárias do Plano de Ação Internacional de Madrid para o Envelhecimento: 1. Pessoas idosas e desenvolvimento; 2. Promoção da saúde e bem-estar na velhice; 3. Criação de um ambiente de vida propício e favorável ${ }^{49}$.

Em 1991, a Assembleia Geral adotou o Princípio das Nações Unidas em Favor das Pessoas Idosas, enumerando 18 direitos das pessoas idosas concernente à independência, à participação, ao cuidado, à

Disponível

em:

<http://www.scielo.br/scielo.php?script=sci_arttext\&pid=S180998232008000100029\&lng=en\&nrm=iso >. Accesso 10 maio 2020.

46 ARAUJO, Claudia Lysia de Oliveira; SOUZA, Luciana Aparecida de; FARO, Ana Cristina Mancussi e. Trajetória das instituições de longa permanência para idosos no Brasil. HERE - História da Enfermagem Revista Eletrônica, Brasília, v. 1, n. 2, p. 250-252, 2010.

Disponível em: < http://www.abennacional.org.br/centrodememoria/here/n2vol1ano1_artigo3.pdf >.

${ }^{47}$ SANTOS, Silvana Sidney Costa. Envelhecimento. Op.cit., p. 92.

48 FEIJÓ, Maria das Candeias Carvalho; MEDEIROS, Suzana da A. Rocha. A Sociedade. Op. cit., p. 115.

49 ONU. A ONU e as pessoas idosas. Disponível em: https://nacoesunidas.org/acao/pessoas-idosas/ Acesso em 10 de julho de 2020. 
autorrealização e à dignidade. No ano seguinte, a Conferência Internacional sobre o Envelhecimento se reuniu para dar prosseguimento ao Plano de Ação, adotando a Proclamação do Envelhecimento. A ação a favor do envelhecimento continuou em 2002, quando a Segunda Assembleia Mundial das Nações Unidas sobre o Envelhecimento foi realizada em Madrid. Objetivando desenvolver uma política internacional para o envelhecimento no século XXI, a Assembleia adotou uma Declaração Política e o Plano de Ação $\underline{\text { Internacional sobre o Envelhecimento de Madrid }}^{50}$.

Na sociedade contemporânea, portanto, a longevidade das pessoas pode ser considerada como uma conquista social, a velhice figura de forma inconteste como uma realidade em todo o mundo e no continente americano, em particular nos países da América Latina é um fenômeno em crescimento, de modo que os governos, cada vez mais, devem atuar políticas públicas voltadas para a integração e bemestar dos idosos, contingente cada vez mais expressivo no conjunto da população. 0 avanço da ciência e das novas tecnologias produziu uma melhor qualidade de vida, aumentando a expectativa de vida sobre o planeta. Nos países latino-americanos atingir esta etapa de vida tem sido um grande desafio para a maioria dos idosos, tendo em vista um contexto social onde ainda se registram profundas desigualdades sociais. Vive-se mais e necessitamos viver com dignidade, sendo esse um dos grandes desafios dos governos de todos os países do continente latino-americano, nesta primeira década do século $21^{51}$.

Destarte, a I Conferência Regional Intergovernamental sobre Envelhecimento na América Latina e Caribe, realizada pela Comissão Econômica para América Latina e Caribe de 19 a 21 de novembro de 2003, em Santiago no Chile, aprovou a Estratégia Regional de Implementação do Plano de Ação Internacional sobre Envelhecimento como instrumento programático de orientação aos governantes dos países do continente. Os compromissos propostos pela I Conferência, acarretam a efetivação de políticas públicas sob a responsabilidade do Estado. A Declaração de Brasília sobre o Envelhecimento, assinada pelos países latino-americanos, por ocasião da realização da II Conferência Intergovernamental sobre Envelhecimento na América Latina e no Caribe, realizada sempre pela Cepal, em Brasília, em dezembro de 2007, com o tema Hacia una sociedad para todas las edades y de protección social basada en derechos, reafirmou os mesmos compromissos. Os compromissos constantes na Declaração de Brasília foram confirmados na III Conferência Intergovernamental sobre Envelhecimento na América Latina e Caribe, realizada em maio de 2012, em São José na Costa Rica com o tema Envejecimiento, solidaridad y protección social: la hora de avanzar hacia la igualdad 52 .

A população brasileira nos últimos anos manteve constante a tendência de envelhecimento e ganhou 4,8 milhões de idosos desde 2012, superando a marca dos 30,2 milhões em 2017, segundo a Pesquisa Nacional por Amostra de Domicílios Contínua - Características dos Moradores e Domicílios, divulgada em 2018 pelo IBGE. Em 2012, a população com 60 anos ou mais era de 25,4 milhões. Os 4,8 milhões de novos idosos em cinco anos correspondem a um crescimento de 18\% desse grupo etário, que tem se tornado cada vez mais representativo no Brasil. As mulheres são maioria expressiva nesse grupo, com 16,9 milhões (56\% dos idosos), enquanto os homens idosos são 13,3 milhões (44\% do grupo) ${ }^{53}$.

De acordo com o site do IBGE, a população brasileira é composta de 29.374 milhões de idosos, o que nos traz um total de $14,3 \%$ da população total do país. Nesse gancho, o Ministério da Saúde confirma que 75,3\% dos idosos dependem única e exclusivamente do Sistema Único de Saúde ${ }^{54}$.

Note-se que no Brasil a construção do Estado Social teve a sua conformação articulada conforme ao modelo de desenvolvimento econômico capitalista, modelo que caracterizou as sociedades neste continente, cuja realidade foi marcada historicamente por processo de exclusão social e desigualdade no acesso às riquezas socialmente produzidas. Ao considerar-se a densidade populacional nas duas últimas décadas, em particular a realidade brasileira, apura-se um crescente aumento do contingente de cidadãos idosos, sendo a preocupação com o processo do envelhecimento da população uma atitude recente na sociedade brasileira. As necessidades e limitações apresentadas pelas pessoas idosas que antes eram assistidas pela caridade de instituições assistenciais confessionais e filantrópicas começam a ser parte

\footnotetext{
50 Ibidem

51 SILVA, Maria de Fátima e; YAZBEK, Maria Carmelita. Proteção social aos idosos: concepções, diretrizes e reconhecimento de direitos na América Latina e no Brasil. Revista Katál, Florianópolis, v. 17, n. 1, p. 103, jan/jun 2014. 52 Ibidem

53 IBGE. Números de idosos cresce 18\% em 5 anos e ultrapassa 30 milhões em 2017. Disponível em: https://agenciadenoticias.ibge.gov.br/agencia-noticias/2012-agencia-de-noticias/noticias/20980-numero-de-idososcresce-18-em-5-anos-e-ultrapassa-30-milhoes-e Acesso em 4/08/2020.

54 Ibidem. Disponível em http://www.saude.gov.br/artigos/810-pessoa-idosa/40816-pessoa-idosa. Acesso $3 / 08 / 2020$.
} 
integrante da agenda pública governamental como prioridade somente no ano de 1988, com o advento da nova Constituição ${ }^{55}$. No Brasil, a preocupação pública com as necessidades acarretadas pelo processo do envelhecimento foi fomentada em grande parte pela organização social dos idosos no país; o protagonismo do movimento social dos trabalhadores aposentados na luta pela garantia de direitos conquistados pela dedicação a uma longa jornada laboral. Esse movimento contribuiu para evidenciar os idosos como um novo sujeito político que podia reivindicar direitos a uma velhice com dignidade. Essa luta acarretou uma ressignificação da velhice na realidade brasileira, pois, deve-se atribuir uma melhor qualidade aos anos acrescidos à existência humana ${ }^{56}$.

Assim sendo, a temática relativa à proteção dos direitos dos idosos até a Constituição de 1988, não foi contemplada, já que as Constituições Federais de 1937, 1927 e 1969 não traziam qualquer norma que tutelasse os direitos de idosos, mas apenas os citavam ao tratar de sua aposentadoria. A Constituição da República Federativa do Brasil de 1988 foi um marco entre o atraso e o avançar do tema, já que estabeleceu como fundamento da República Federativa do Brasil a dignidade da pessoa humana, princípio que engloba todos, sem exclusão de idade ou gênero.

M. B. Dias comentando a dignidade da pessoa humana relata que é princípio indispensável ao Estado Democrático de Direito, visto que promove os direitos humanos e a justiça social para todas as pessoas, sendo, claro, responsável por um olhar mais humano que valorize as pessoas ${ }^{57}$.

Em 1994, buscando-se a efetivação das garantias constitucionais no campo das políticas destinadas ao público idoso, foi promulgada a Política Nacional do Idoso (PNI), Lei n. 8.842, de 04 de janeiro, que estabelece no seu artigo $1^{\text {o }}$ como objetivo a necessidade de se "assegurar os direitos sociais do idoso, criando condições para prover a sua autonomia, integração e participação efetiva na sociedade", tendo a família, a sociedade e o Estado iguais responsabilidades na provisão de condições que permita a essa minoria social o exercício pleno de sua cidadania. Contudo, antes da promulgação da PNI, em 1993, a lei Orgânica da Assistência Social (Loas), Lei, n. 8.742, de 7 de dezembro, já havia reconhecido a pessoa idosa como um dos seus segmentos de atenção prioritária. Como desdobramento da lei Orgânica de Saúde, aprovada em 1990, Lei n. 8.8080/1990 que assegurou o direito universal e integral à saúde, foi estabelecida em 1999, a Política Nacional de Saúde do Idoso, mediante Portaria Ministerial n. 1.395/1999 e regulamentada pela Portaria n. 2.528 de outubro de 2006 que a renomeou como Política Nacional de Saúde da Pessoa Idosa, estabelecendo como uma de suas diretrizes a promoção do envelhecimento ativo e saudável, de acordo com as recomendações da O.N.U ${ }^{58}$

Em 2003, foi sancionada a lei no 10.741 , o Estatuto do Idoso, com a finalidade de proteger a qualidade de vida dos idosos, reinserindo-os na sociedade e tendo como objetivo resguardar os direitos constitucionais e assegurar a dignidade dessas pessoas, sem discriminá-los.

\section{OS DIREITOS DA PESSOA IDOSA NO ORDENAMENTO JURÍDICO BRASILEIRO.}

Em 2003 quando o Estatuto do Idoso estava em fase de elaboração, uma novela de Manoel Carlos intitulada "Mulheres Apaixonadas" teve um grande sucesso, a trama apresentava uma personagem chamada Dóris que destratava e roubava os avós, tal comportamento gerou uma comoção social e, de alguma forma, a opinião pública pressionou o Poder Legislativo para que a Lei 7.209/84, que havia introduzido algumas modificações no Código Penal, mas não previa punições para maus tratos contra os idosos, fosse atualizada. Segundo alguns autores a novela agilizou a aprovação do Estatuto que tramitava

\footnotetext{
550 artigo 30 da Constituição Federal de 1988 reconheceu "o dever da família, da sociedade e do Estado de amparar as pessoas idosas, assegurando sua participação na comunidade, defendendo sua dignidade e bem-estar social e garantindo-lhes o direito à vida".

56 SILVA, Maria de Fátima e; YAZBEK, Maria Carmelita. Proteção social. Op. cit., pp. 105-107.

57 DIAS, Maria Berenice. Manual de Direito das Famílias. São Paulo. Revista dos Tribunais, 2016, p. 83.

A Constituição veda discriminação em razão da idade, bem como assegura especial proteção ao idoso. Atribui à família, à sociedade e ao Estado o dever de assegurar sua participação na comunidade, defendendo sua dignidade e bem-estar, bem como lhe garantindo o direito à vida ( $\mathrm{CF} 230$ ). É determinada a adoção de políticas de amparo aos idosos, por meio de programas a serem executados, preferentemente, em seus lares (CF $230 \S 1$ 1.ํ). $^{\circ}$ ).

58 SILVA, Maria de Fátima e; YAZBEK, Maria Carmelita. Proteção social. Op. cit., p. 107.
} 
no Congresso há sete anos! Diante da pressão social, o Legislativo preparou e promulgou a Lei 10.741/03, o Estatuto do Idoso ${ }^{59}$.

O Estatuto do Idoso traz no seu título I as Disposições Gerais, definindo como `idoso` a pessoa com 60 anos ou mais, adotando o legislador o critério cronológico para estabelecer os que gozam da proteção assegurada pelo Estatuto, a qual se fundamenta na efetivação do princípio da dignidade humana, conforme aos ditames da nossa Carta Magna em seu artigo $230^{60}$ que estabelece o amparo aos idosos por parte do Estado, da sociedade e da família. Os direitos fundamentais dos idosos estão especificados no título II, dentre eles o direito à saúde, à liberdade, ao respeito, à dignidade, aos alimentos, entre outros direitos ${ }^{61}$. É composto por 118 artigos, que visam proteger direitos dessa minoria relacionados à vida, à alimentação, à saúde, à dignidade, à educação, à cultura, ao esporte, ao lazer, à profissionalização de acordo com sua capacidade, à previdência social, à assistência social, à habitação, ao transporte e à proteção, às entidades de apoio ao idoso e à fiscalização.

Dentro desses direitos e garantias se ressalta o direito à saúde, que de acordo com o artigo 15 do Estatuto que dispõe que fica assegurada a atenção integral à saúde do idoso por intermédio do Sistema Único de Saúde-SUS devendo ser-lhe garantido o acesso universal e igualitário para a prevenção, promoção, proteção e recuperação da, com particular atenção às doenças afetam essencialmente os idosos.

A partir do caráter normativo do princípio da dignidade da pessoa humana, todos fazem jus a viver dignamente, gozando de saúde, em qualquer etapa de sua existência. Como os idosos são propensos às enfermidades imanentes da velhice, sua saúde, quando em bom estado, deve ser preservada a todo custo e, quando deficitária, precisa ser reabilitada prioritariamente, pois, saúde é vida com dignidade ${ }^{62}$. No entender de E. Moraes, na área da saúde, a rápida transição demográfica e epidemiológica traz grandes desafios, pois se mostra responsável pelo surgimento de novas demandas de saúde, especialmente a "epidemia de doenças crônicas e de incapacidades funcionais", resultando em maior e mais prolongado uso de serviços de saúde ${ }^{63}$.

Franco, Reis e Fialho salientam que o Estatuto do Idoso estabeleceu uma nova fase na tutela do direito do idoso, firmando definitivamente o direito à saúde como uma questão social de substancial importância, assegurado através do Sistema Único de Saúde - SUS64. Ora, o Brasil caminha rapidamente para um perfil demográfico mais envelhecido caracterizado por uma transição epidemiológica, onde as doenças crônico degenerativa ocupam um lugar de destaque; esse incremento de doenças crônicas implica a necessidade de ajustes nas políticas públicas, em particular no que concerne as direcionadas ao atendimento da crescente demanda na aérea da saúde, previdência e assistência social ${ }^{65}$.

Nesse diapasão, os serviços de saúde prestados pelo Estado aliados a falta de políticas públicas se apresentam pouco eficazes na garantia da efetivação do direito à saúde do idoso. Existem falhas na assistência farmacêutica para aquisição e fornecimento de medicamentos e de insumos terapêuticos, insuficiência de profissionais e de equipamentos adequados. Esses fatores contribuem significativamente que essa camada populacional procure garantir seu direito à saúde através do Poder Judiciário. Não se trata apenas de fornecer medicamentos e atendimento especializado, mas de proteger e preservar a integridade física e moral da pessoa idosa, sua dignidade enquanto pessoa humana e acima de tudo à vida,

${ }^{59}$ ELLWANGER, Ester. 0 Fazer Jornalístico Refletido no Âmbito da Novela - Estudo de Caso da Novela Mulheres Apaixonadas. Comunologia. Revista de Comunicação da Universidade Católica de Brasília, Brasília, v. 9, n.1, p. 95.jan./jun. 2016.

60 BRASIL. Constituição da República Federativa do Brasil de 05 de outubro de 1988. "Art. 230. A família, a sociedade e o Estado têm o dever de amparar as pessoas idosas, assegurando sua participação na comunidade, defendendo sua dignidade e bem-estar e garantindo-lhes o direito à vida."

61 BRASIL. Estatuto do Idoso. Lei Nr.10.741, de 1o de outubro de 2003, Art. 8o , "TíTULO II. Dos Direitos Fundamentais. CAPÍTULO I. Do Direito à Vida. Art. 8o 0 envelhecimento é um direito personalíssimo e a sua proteção um direito social, nos termos desta Lei e da legislação vigente."

62 BARLETTA, Fabiana Rodrigues. A pessoa idosa e seu direito prioritário à saúde: apontamentos a partir do princípio do melhor interesse do idoso. R. Dir. sanit., São Paulo v.15 n.1, p. 126, mar./jun. 2014.

63 MORAES, Edgar Nunes. Atenção à Saúde do Idoso: Aspectos Conceituais. Brasília: Organização Pan-Americana de Saúde, 2012, p. 12.

64 FRANCO, Márcia Villar; REIS, Karina Pregnolato; FIALHO, Marcelito Lopes. A Judicialização do Direito à Saúde do Idoso. Âmbito Jurídico, São Paulo, 2019. Disponível em: $<$ https://ambitojuridico.com.br/cadernos/direitos-humanos/a-judicializacao-do-direito-a-saude-do-idoso/> Acesso em 05 de setembro de 2019.

65 MORAES, Edgar Nunes. Atencão. Op. cit., 2012, p. 10. 
bem maior protegido por nosso ordenamento jurídico ${ }^{66}$. 0 Estado se mostra como maior violador desse direito. Resta claro, que são inúmeros os desafios enfrentados, diariamente, pelo Poder Público para que tal política se mostre eficiente e eficaz ${ }^{67}$.

O idoso tem direito a receber seu tratamento pelo SUS conforme previsão legal, cabendo ao Poder Público fornecer de maneira gratuita medicamentos, próteses e outros recursos relativos a tratamentos ${ }^{68}$. Diante do falho atendimento fornecido pelo SUS, muitos idosos sacrificam necessidades básicas para arcar com o custo de planos particulares. Tendo em vista tal situação o Estatuto veda em seu art. $15 \S 3$ a discriminação do idoso nos planos de saúde pela cobrança de valores diferenciados em razão da idade, objetivando, assim, garantir a dignidade do idoso ao prever a proibição de discriminações pela cobrança de valores abusivos em razão da sua faixa etária. Neste sentido a jurisprudência pátria:

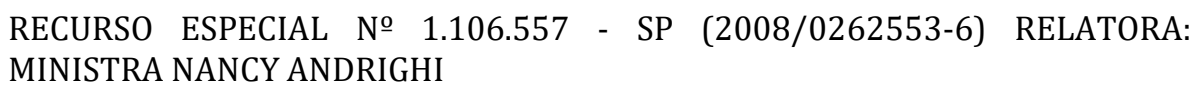
conhecido e provido. ACÓRDÃo Vistos, relatados e discutidos estes autos, acordam os Ministros da Terceira Turma do Superior Tribunal de Justiça, na conformidade dos votos e das notas taquigráficas constantes dos autos Prosseguindo no julgamento, após o voto-vista do Sr. Ministro Massami Uyeda, por unanimidade, dar provimento ao recurso especial, nos termos do voto do(a) Sr(a). Ministro(a) Relator(a). Os Srs. Ministros Massami Uyeda, Sidnei Beneti, Vasco Della Giustina e Paulo Furtado votaram com a Sra. Ministra Relatora. Brasília (DF), 16 de setembro de 2010(Data do Julgamento). MINISTRA NANCY ANDRIGHI Relatora. ${ }^{69}$

Deve-se ressaltar que o Colendo Superior Tribunal de Justiça já havia apreciado em 2012 a questão relativa à incidência do CDC nas relações entre pessoas jurídicas, afirmando que "o que deve nortear a aplicação da norma ao caso concreto é a vulnerabilidade da pessoa contratante", de modo a garantir o ideal de garantia de igualdade material entre fornecedores e consumidores ${ }^{70}$. Atualmente, é notório que os planos de saúde individuais escasseiam, posto que as operadoras de planos de saúde e de seguro saúde se interessam mais pelos planos coletivos, pois esses permitem a adequação em massa dos contratos aos seus interesses. Nesse âmbito, excluir os contratos coletivos do alcance do CDC, ou mesmo mitigar a

\footnotetext{
66 FRANCO, Márcia Villar; REIS, Karina Pregnolato; FIALHO, Marcelito Lopes. A Judicialização. Op. cit., s/p.

${ }^{67}$ FALEIROS, V. P. Violência na Velhice. Revista O Social em Questão, n. 11, 2004, p. 19.

${ }^{68}$ BRASIL. Estatuto do Idoso. Lei №.10.741, de 1ํ de outubro de 2003, Art. 15 § 2‥ "Art. 15. É assegurada a atenção integral à saúde do idoso, por intermédio do Sistema Único de Saúde - SUS, garantindo-lhe o acesso universal e igualitário, em conjunto articulado e contínuo das ações e serviços, para a prevenção, promoção, proteção e recuperação da saúde, incluindo a atenção especial às doenças que afetam preferencialmente os idosos. (...) § 20 Incumbe ao Poder Público fornecer aos idosos, gratuitamente, medicamentos, especialmente os de uso continuado, assim como próteses, órteses e outros recursos relativos ao tratamento, habilitação ou reabilitação".

${ }^{69}$ STJ-Superior Tribunal de Justiça. REsp № 1.106.557 - SP (2008/0262553-6). Disponível em https://stj.jusbrasil.com.br/jurisprudencia/17406501/recurso-especial-resp-1106557-sp-2008-0262553-6stj/relatorio-e-voto-17406503?ref=juris-tabs Acesso em 19 de agosto de 2019.

70STJ-Superior Tribunal de Justiça. REsp no 1.195.642 - RJ (2010/0094391-6). Disponível em: https://stj.jusbrasil.com.br/jurisprudencia/22829799/recurso-especial-resp-1195642-rj-2010-0094391-6stj/relatorio-e-voto-22829801 Acesso 19 de agosto de 2019
} 
proteção consumerista a esses contratos, ao argumento de se tratar de contratação entre "pessoas jurídicas", significa, na prática, excluir da proteção legal milhões de consumidores ${ }^{71}$.

Por outro lado, em relação à discussão sobre a validade ou não do reajuste em razão da faixa etária, o Superior Tribunal de Justiça, em regime de recursos repetitivos (Tema 952), em 14.12.2016, no julgamento do Recurso Especial oㅜ 1.568.244 RJ, de relatoria do Ministro Ricardo Villas Bôas Cueva, acolheu a tese da validade do reajuste de mensalidade de plano de saúde individual ou familiar fundado na mudança de faixa etária do beneficiário, "desde que a) haja previsão contratual, b) sejam observadas a normas expedidas pelo órgãos governamentais reguladores e c) não sejam aplicados percentuais desarrazoados ou aleatórios que, concretamente e sem base atuarial idônea, onerem excessivamente o consumidor ou discriminem o idoso":

“RECURSO ESPECIAL REPETITIVO. NEGATIVA DE PRESTAÇÃO JURISDICIONAL. NÃO OCORRÊNCIA. CIVIL. PLANO DE SAÚDE. MODALIDADE INDIVIDUAL OU FAMILIAR. CLÁUSULA DE REAJUSTE DE MENSALIDADE POR MUDANÇA DE FAIXA ETÁRIA. LEGALIDADE. ÚLTIMO GRUPO DE RISCO. PERCENTUAL DE REAJUSTE. DEFINIÇÃO DE PARÂMETROS. ABUSIVIDADE. NÃO CARACTERIZAÇÃO. EQUILÍBRIO FINANCEIRO-ATUARIAL DO CONTRATO72.

A partir desse julgado da Colenda Corte se discute se o reajuste em razão da faixa etária pode ser aplicado aos planos de saúde coletivos. 0 relator do acórdão, ministro Paulo de Tarso Sanseverino, designou audiência pública, que se realizou no dia 10 de fevereiro de 2020. A discussão é de grande importância prática dada a multiplicidade de demandas a respeito do assunto. Com efeito, nos últimos anos houve uma significativa redução da oferta de planos individuais e familiares comparativamente aos coletivos, em razão principalmente do maior controle dos seus reajustes anuais pela Agência Nacional de Saúde ${ }^{73}$.

Destarte, em 10 de fevereiro passado, a 2a Seção do Superior Tribunal de Justiça realizou audiência pública para ouvir opiniões da sociedade acerca da validade do reajuste por faixa etária em planos de saúde coletivos. Vários foram os expositores, representantes do Ministério Público Federal, da Defensoria Pública da União (DPU), da Federação Nacional de Saúde Suplementar, da Agência Nacional de Saúde Suplementar (Anvisa), do Instituto Brasileiro de Defesa do Consumidor, da União Nacional das Instituições de Autogestão em Saúde, dentre outras entidades, a audiência teve por fim prover subsídios para o julgamento do Tema 1.016 de recursos repetitivos acerca da matéria. Indo-se além do aspecto emocional do debate, deve-se considerar outras substanciais questões, notadamente o respeito à legislação e à regulamentação da agência reguladora, o grau de escolha dos beneficiários, a prévia aprovação dos reajustes por parte da agência e o próprio equilíbrio econômico-financeiro dos contratos, estabelecido pelo binômio fundamental do contrato de plano de saúde, qual seja prêmio versus risco. A norma relativa ao reajuste por faixa etária é a Resolução Normativa 63, da ANS, cujas regras são: a) o valor fixado para a última faixa não pode ser superior a seis (6) vezes o valor da primeira, e b) a variação acumulada entre a sétima e a décima faixas não poderá ser superior à variação acumulada entre a primeira e a sétima. Ora, levando-se em conta que o plano atende às normas setoriais, pode-se considerar os reajustes aleatórios ou desarrazoados? Note-se, ainda, que os percentuais do reajuste por faixa etária somente podem ser comercializados após o aval da ANS $^{74}$.

Saliente-se que o STJ já fixou a tese jurídica, no Tema 952, sobre a validade da cláusula de reajuste por faixa etária em planos individuais ou familiares, desde que haja previsão contratual, seja observada a regulamentação do setor e não sejam aplicados percentuais desarrazoados ou aleatórios que onerem excessivamente o consumidor ou discriminem o idoso. Por fim, considerando que inexiste diferença entre

\footnotetext{
${ }^{71}$ LEYSER, Maria Fátima Vaquero Ramalho. Reajuste de plano ou seguro de saúde em razão de mudança de faixa etária. Disponível em: https://www.conjur.com.br/2020-jan-27/mp-debate-reajuste-plano-saude-razao-mudanca-faixaetaria Acesso em 19 de agosto de 2019.

72 STJ-Superior Tribunal de Justiça. REsp 1.568.244-RJ (2015/0297278-0). Disponível em https://stj.jusbrasil.com.br/jurisprudencia/416939208/recurso-especial-resp-1568244-rj-2015-0297278-0/inteiroteor-416939214

${ }^{73}$ REINIG, Guilherme Henrique Lima; SOUZA, Viviane Isabel Daniel Speck de. STJ volta a afetar tema do reajuste etário nos planos de saúde. Consultor Jurídico, São Paulo, 2020. Disponível em: https://www.conjur.com.br/202 -jan-27/stjvolta-afetar-tema-reajuste-etario-planos-saude Acesso em 20/08/2019.

${ }^{74}$ CONDE, Luiz Felipe; CARVALHO, Francisco. Audiência pública no STJ debate sobre o reajuste por faixa etária nos planos coletivos. Consultor Jurídico, São Paulo, 2020. Disponível em https://www.conjur.com.br/2020-mar-17/stjdebate-reajuste-faixa-etaria-planos-coletivos Acesso em 14 de julho de 2020
} 
as normas regulamentares acerca de tal espécie de reajuste entre os planos individuais e os coletivos parece, não haver motivos para alteração por parte do STJ da tese supracitada 75 .

No quadro do sistema de proteção do idoso, particular importância vem adquirindo a categoria dos idosos com mais de 80 anos. Prova disso é edição da Lei 13.466/2017 que acrescenta ao art. 3 do Estatuto do Idoso o § 2 reconhecendo que "dentre os idosos, é assegurada prioridade especial aos maiores de oitenta anos, atendendo-se suas necessidades sempre preferencialmente em relação aos demais idosos."76

A longevidade da população idosa que inicia aos 60 anos, tem aumentado sua expectativa de vida, sendo cada vez mais comum no Brasil idosos com mais de 80 anos; esse público atualmente vem dividindo espaços com os mais jovens na busca de aceitação, em ônibus e universidades ${ }^{77}$. Essa "quarta idade" busca uma melhor qualidade de vida, sendo necessário a criação de atividades voltadas para eles, através das quais possam realizar seus sonhos abandonados na juventude.

Se observamos os centros de convivência dos idosos eles ainda precisam ser melhor preparados para dar suporte a essas pessoas, pois, nem todos sofreram a ação do tempo de modo igual, certamente essas pessoas possuem suas limitações, mas nem todas sofrem problemas de memória crônicos ou problemas de saúde; ademais, o avanço da indústria de medicamentos tem propiciado um aumento da qualidade de vida de um idoso com mais de 80 anos.

Para esses idosos muito ainda tem que ser pensado, estruturas que estimulem sua prevalência e ofertem aquilo que eles procurem, atividades que supram a necessidade dessas pessoas, nas questões de diretrizes públicas, como os conselhos do idoso não possuem apoio. Passa-se a considerar a hipótese de um projeto de lei que crie os conselhos tutelares dos idosos, que realizem o papel que o conselho tutelar da infância.

$\mathrm{Na}$ área de saúde pública poder-se-ia pensar em áreas destinadas ao atendimento desse público com geriatras e gerontologistas permitindo maior dignidade a essas pessoas, que em vários precisam de cuidado e atenção maior.

Não há dúvida de que criar apenas o dia dos avós nos calendários é muito pouco, existe a necessidade de ensinar o papel do idoso na sociedade e isso pode começar nas instituições de educação básica, dessa forma a próxima geração crescerá sabendo compreender a importância do idoso suas necessidades e projetar isso em ações práticas.

Dessa forma podemos afirmar que muito ainda precisa ser feito para essas pessoas, mas para isso possa ser feito convenientemente é necessário conhecer e compreender a mente do idoso, suas necessidades fisiológicas, mas também existenciais, suas dúvidas, medos, anseios o que ele precisa e quer fazer na $4^{\circ}$ idade $^{78}$.

\section{CONSIDERAÇÕES CONCLUSIVAS}

A sociedade brasileira, ainda reluta em valorizar seus idosos, perpetuando uma cultura de valorização dos jovens. É notório que nem todos os idosos envelheceram com qualidade de vida, sendo esse um problema comum em países subdesenvolvidos onde as políticas públicas existem mais no papel que em ações práticas.

Dessa forma a falta de informação e ações que permitam que os idosos recebam aquilo que lhe é garantido na CF/88 torna ineficaz muitas normas constitucionais. Podemos observar que a criação do Conselho Nacional do Idoso pela Lei $8.842 / 84$, não resultou em ações práticas de proteção ao idoso, sendo sancionada a Lei 10.741/2003 que fixou a obrigação da família, da comunidade da sociedade e do Poder Público assegurar ao idoso, com absoluta prioridade, a efetivação do direito à vida, à saúde, à alimentação, à educação, à cultura, ao esporte, ao lazer, ao trabalho, à cidadania, à liberdade, à dignidade, ao respeito e à convivência familiar e comunitária (art. 3 da Lei 10.741/2003).

\footnotetext{
75 Ibidem

${ }^{76}$ BRASIL. Lei no 13.466 , de 12 de julho de 2017. “Art. 2o 0 art. 3o da Lei no 10.741 , de $1^{\text {o }}$ de outubro de 2003 , passa a vigorar acrescido do seguinte $\S 2^{\circ}$, renumerando-se o atual parágrafo único para $\S 1^{\circ}$ : $:(.$.

$\S 2$ o Dentre os idosos, é assegurada prioridade especial aos maiores de oitenta anos, atendendo-se suas necessidades sempre preferencialmente em relação aos demais idosos." (NR)"

77 OLIVEIRA, Nielmar. Expectativa de vida do brasileiro cresce e mortalidade infantil cai. Agência Brasil. Disponível em $<$ www.agenciabrasil.ebc.com.br>. Acesso em 20 de agosto de 2019.

78 PINHEIRO, Hudson Azevedo. Entrevista a "Tarde Nacional" - Você sabe o que é 'quarta idade'?. Disponível em: $<$ https://radios.ebc.com.br/tarde-nacional/2017/08/> Acesso em 2 de julho de 2020.
} 
Ademais, o Estatuto estabeleceu punições aos autores de violência de qualquer tipo contra os idosos. Nesse quadro existem três definições de violência: a) a violência estrutural (desigualdades sociais); b) aquela interpessoal (violência física, verbal, moral) e, por fim, a institucional (quando está ligada diretamente ao estado). Infelizmente em um país cheio de diferenças e desigualdades, os idosos são vítimas constantes de inúmeras violências, tendo seus direitos constantemente cerceados, num momento de contínuas crises, principalmente, as crises materiais, como a falta de atendimento médico, hospitalar, transporte de qualidade, lazer e segurança pública, sendo esses sujeitos uma das categorias mais prejudicadas, dada a sua vulnerabilidade.

\section{REFERÊNCIAS}

\section{FONTES}

[1] BRASIL. Constituição da República Federativa do Brasil De 1988 . Disponível em: <http://www.planalto.gov.br/ccivil_03/constituicao/constituicao.htm>. Acesso em: 08 Out 2019.

[2] BRASIL. Lei n. 10.741, de 1ํ de outubro de 2003. Dispõe sobre o Estatuto do Idoso e dá outras providências. Disponível em: <http://www.planalto.gov.br/ccivil_://www03/leis/2003/L10.741.htm >

[3] BRASIL. Lei no 8.842, de 4 de janeiro de 1994. Dispõe sobre a política nacional do idoso, cria o Conselho Nacional do Idoso e dá outras providências. Disponível em: <http://www.planalto.gov.br/ccivil_03/leis/l8842.htm>. Acesso em: 08 Out 2019.

[4] BRASIL. Ministério da Saúde. Saúde da Pessoa Idosa: Prevenção e Promoção à Saúde Integral. Disponível em: <http://www.saude.gov.br/saude-de-a-z/saude-da-pessoa-idosa/>

[5] BRASIL. Ministério da Saúde. Estudo aponta que 75\% dos idosos usam apenas o SUS. Disponível em: <http://www.saude.gov.br/saude-de-a-z/saude-da-pessoa-idosa/>

[6] DOUTRINA

[7] ALONSO, Fábio Roberto Bárboli. Envelhecendo com Dignidade: O Direito dos Idosos como o Caminho para a Construção de uma Sociedade para Todas as Idades. UFF/ Programa de Pós-Graduação em Sociologia e Direito. Niterói, 2005.

[8] AMAZONAS, Diário do. Delegacia do Idoso orienta sobre medidas protetivas para homens e mulheres. Disponível .em <www.diarioam.com.br>, acesso em 18 de agosto de 2019

[9] BARLETTA, Fabiana Rodrigues. A pessoa idosa e seu direito prioritário à saúde: apontamentos a partir do princípio do melhor interesse do idoso. R. Dir. sanit., São Paulo v.15 n.1, p. 119-136, mar./jun. 2014.

[10] DIAS, Maria Berenice. Manual de Direito das Famílias. 11 ed. rev., atual. Ampl., São Paulo: Revista dos Tribunais, 2016.

[11] ELLWANGER, Ester. O Fazer Jornalístico Refletido no Âmbito da Novela - Estudo de Caso da Novela Mulheres Apaixonadas. COMUNICOLOGIA - v.9 - n.1, jan./jun. 2016. Revista de Comunicação da Universidade Católica de Brasília. ISSN 1981-2132 93

[12] FALEIROS, V. P. Violência na Velhice. Rev. O Social em Questão, n. 11, 2004.

[13] IBGE. Para complementar renda, idosos retardam saída do mercado de trabalho. Disponível em: <https://cnts.org.br/noticias/para-complementar-renda-idosos-retardam-saida-do- mercado-de-trabalho/>. Acesso: 08 Out 2019.

[14] IPEA. Idosos continuam como força de trabalho. Disponível em: <https://cnts.org.br/noticias/paracomplementar-renda-idosos-retardam-saida-do-mercado-de-trabalho/>. Acesso em: 08 Out 2019.

[15] FEIJÓ, Maria das Candeias Carvalho; MEDEIROS, Suzana da A. Rocha. A Sociedade Histórica dos Velhos e a Conquista de Direitos. Revista Kairós Gerontologia, 14(1), ISSN 2176-901X, São Paulo, Educ/NEPE.

[16] FRANCO, Márcia Villar; REIS, Karina Pregnolato; FIALHO, Marcelito Lopes. A Judicialização do Direito à Saúde do Idoso. Âmbito Jurídico. Disponível em: <https://ambitojuridico.com.br/cadernos/direitos-humanos/ajudicializacao-do-direito-a-saude-do-idoso/> Acesso em 05 de setembro de 2019.

[17] FUSSEL, Sidney. O Japão está usando adesivos de QR code para identificar idosos. Gizmodo Brasil. Disponível em: https://gizmodo.uol.com.br/japao-qr-codes-idosos-demencia/ Acesso em 10 de agosto de 2019

[18] LAO-TZY. Tao-te King. O livro do sentido da vida. Tradução de Margit Marticia. São Paulo: Pensamento, 1999.

[19] LIMA, Lorenna. Breve histórico dos direitos dos idosos no Brasil e no mundo. Disponível em: https://jus.com.br/artigos/71311/breve-historico-dos-direitos-dos-idosos-no-brasil-e-no-mundo. Acesso em 07 de outubro de 2019.

[20] LIMA, Airton., AZEVEDo, Valéria Vanda, BARROS, Angela Maria Abreu. A vulnerabilidade do idoso em situações de desastres: necessidade de uma política de resiliência eficaz. Revista Ambiente \& Sociedade. São Paulo v. XVII, n. 2 n p. 157-174 n abr.-jun. 2014

[21] MORAES, Edgar Nunes de. Atenção à Saúde do Idoso: Aspectos Conceituais. 1a edição. Brasília: Organização Pan-Americana da Saúde, 2012.

[22] OLIVEIRA, Nielmar. Expectativa de vida do brasileiro cresce e mortalidade infantil cai. Agência Brasil. Disponível em <www.agenciabrasil.ebc.com.br>. Acesso em 20 de agosto de 2019

[23] PARANHOS, Denise Gonçalves de Araújo Mello e. Direitos humanos dos pacientes idosos. Disponível em:

[24] <http://repositorio.unb.br/bitstream/10482/32794/1/2018_DeniseGon\%c3\%a7alvesdeAra\%c3\%bajoMe lloeParanhos.pdf> Acesso em: 08 Out 2019. 
[25] PINHEIRO, Hudson Azevedo. Entrevista a "Tarde Nacional" - Você sabe o que é 'quarta idade'?. Disponível em: https://radios.ebc.com.br/tarde-nacional/2017/08/ Acesso em 2 de julho de 2020

[26] SANTOS, Silvana Sidney Costa. Envelhecimento: visão de filósofos da antiguidade oriental e ocidental. Rev. RENE. Fortaleza, /2001.

[27] SANTOS, Claudia Rodrigues dos. O Idoso no Brasil: da Velhice Desamparada a Velhice dos Direitos? UCAM, 2007 


\section{Capítulo 3}

\section{Aspectos previdenciários}

Maria do Perpetuo Socorro Oliveira de Souza

Josany Keise de Souza David

Rebecca Cinque de Oliveira 
A Previdência Social é uma garantia constitucional instituída desde a Carta Magna de $1988^{79}$, pertencente ao tripé da Seguridade Social: Saúde, Previdência Social e Assistência Social, que se apresentam como verdadeiras liberdades positivas dentro do ordenamento jurídico baseado em um Estado Social de Direito.

Diante desse cenário, a Previdência Social tem por finalidade dar proteção social a todo cidadão, visando à concretização da igualdade social, independente de contribuição direta aos cofres públicos, tendo em vista que visa tutelar serviços e valores para a garantia do mínimo ao ser social. Por mínimo, entenda-se as necessidades vitais básicas que se encontram expressas no art. $7^{\circ}$, IV da CRFB/88, a saber: "[...] moradia, alimentação, educação, saúde, higiene, lazer, vestuário, transporte e previdência social”80.

Ressalta-se que, o direito previdenciário brasileiro tem sua origem na Constituição de 1824, sendo considerado expressamente no Art. 179, inciso XXXI de “[...] socorros públicos"81 e apesar de haver essa previsão, o dispositivo em sua aplicabilidade era inexistente a maioria dos cidadãos.

É sabido que embora tenha sido referência em outras Constituições, o direito previdenciário só veio a ser melhor reconhecido, como ditames fundamentais e principiológicos, a partir da Constituição de 1988, haja vista que incorporou a participação do Poder Público e da sociedade, ou seja, os setores públicos e privados.

Nesse contexto, foi criada a Lei 8.213 de $1991^{82}$, que apresenta caráter securitário, no qual dispõe sobre os planos de benefícios da previdência social de modo a regulamentar o amparo aos segurados mediante contribuição, que tem por fim garantir aos seus beneficiários os meios indispensáveis a participação social face a ocorrência de riscos ou demais contingências sociais.

Insta frisar que, a Previdência Social, em regra, pode ser comparada a um contrato social com o Estado, uma espécie de seguro coletivo e individual no qual o cidadão realiza contribuições pecuniárias, ao exercer atividade remuneratória, ao Regime Geral de Previdência Social (RGPS) e em troca possui a garantia assecuratória dos seus direitos fundamentais.

Desse modo, todo cidadão que contribui com a Previdência Social é chamado de segurado e aqueles que possuem liame jurídico com este é chamado de dependente, também denominado pela lei de contribuinte direto do sistema previdenciário.

Contudo, ressalta-se, ainda, que a Constituição Federal de 1988 expressamente dispõe que o assistencialismo social será prestado a quem dela necessitar. Logo, caso o cidadão não realize as contribuições pecuniárias, deverá preencher requisitos assecuratórios que possibilitará direito às prestações previdenciárias conforme determina a lei. Assim, nas palavras de Souza:

Previdência Social é a forma de atendimento das contingências sociais mediante captação prévia de recursos. As principais características da previdência social são: (1) ao objeto: obrigação de garantir determinadas prestações quando se verifica um determinado evento; (2) ao campo de aplicação: clientela definida (pessoas que exerceram ou exercem atividades remuneradas); (3) aos recursos: fixação das contribuições prévias de responsabilidade do segurado, do empregador e do Estado. A Constituição Federal estabelece que a Previdência Social será organizada sob a forma de regime geral, de caráter contributivo, de filiação obrigatória, observados os critérios que preservem o equilíbrio financeiro e atuarial, devendo atender às seguintes contingências: doença; invalidez; morte e idade avançada; proteção ao trabalhador em situação de desemprego involuntário; salário-família e auxílio-reclusão para os dependentes dos segurados) de baixa renda e pensão por morte do segurado, homem ou mulher, ao cônjuge ou companheiro e dependentes. ${ }^{83}$

\footnotetext{
${ }^{79}$ Disponível em: http://www.planalto.gov.br/ccivil_03/constituicao/constituicao.htm. 12 de junho de 2019.

80 Idem.

81 Disponível em: http://www.planalto.gov.br/ccivil_03/constituicao/constituicao24.htm. Acesso: 12 de junho de 2019.

82 Disponível em: http://www.planalto.gov.br/ccivil_03/leis/18213cons.htm. Acesso: 12 de junho de 2019.

83 SOUZA, Lilian Castro de. Direito Previdenciário. Provas e Concursos. 4 ed. São Paulo: Atlas, 2009, p. 27.
} 
Outro ponto a ser observado, é que a Previdência Social está pulverizada de princípios, dentre eles o da solidariedade das contribuições. Isso significa dizer que os cidadãos economicamente ativos, fazem suas contribuições e garantem os benefícios previdenciários aos que não se encontram em categorias profissionais ou em outra relação de trabalho em exercício. Nesse sentido leciona Castro e Lazzari:

A Previdência Social se baseia, fundamentalmente, na solidariedade entre os membros da sociedade. Assim, como a noção de bem-estar-coletivo repousa na possibilidade de proteção de todos os membros da coletividade, somente a partir da ação coletiva de repartir os frutos do trabalho, com a cotização de cada um em prol do todo, permite a subsistência de um sistema previdenciário. Uma vez que a coletividade se recuse a tomar como sua tal responsabilidade, cessa qualquer possibilidade de manutenção de um sistema universal de proteção social. Ressalta Daniel Machado da Rocha que "a solidariedade previdenciária legitima-se na ideia de que, além de direitos e liberdades, os indivíduos também têm deveres para com a comunidade na qual estão inseridos", como o dever de recolher tributos (e contribuições sociais, como espécies destes), ainda que não haja qualquer possibilidade de contrapartida em prestações. Envolve pelo esforço individual, o movimento global de uma comunidade em favor de uma minoria - os necessitados de proteção - de forma anônima). ${ }^{84}$

Assim, para que a Previdência Social seja meio aplicável ao atendimento de contingências sociais, necessita valer-se da Administração Pública Indireta, no caso a Autarquia Federal - Instituto Nacional de Seguridade Social - INSS, a qual possui personalidade jurídica de direito público e está vinculada ao Ministério da Previdência Social.

O INSS tem a incumbência precípua da organização da previdência social, administrando as prestações e benefícios de natureza assistencial desde que o segurado preencha todos os requisitos legais exigidos.

\section{BENEFÍCIOS PREVIDENCIÁRIOS}

Os benefícios previdenciários estão elencados no art. 18 da Lei 8.213 de 1991, nos quais podemos identificar três grupos distintos: as aposentadorias programáveis, os benefícios por incapacidade laboral, e os benefícios de proteção à família e à maternidade. In verbis:

Art. 18. O Regime Geral de Previdência Social compreende as seguintes prestações, devidas inclusive em razão de eventos decorrentes de acidente do trabalho, expressas em benefícios e serviços:

I - quanto ao segurado:

a) aposentadoria por invalidez;

b) aposentadoria por idade;

c) aposentadoria por tempo de contribuição;

d) aposentadoria especial;

e) auxílio-doença;

f) salário-família;

g) salário-maternidade;

h) auxílio-acidente;

II - quanto ao dependente:

a) pensão por morte;

b) auxílio-reclusão;

${ }^{84}$ CASTRO, Carlos Alberto Pereira de; LAZZARI, João Batista. Manual de Direito Previdenciário. 20 ed. Rio de Janeiro: Forense, 2017, p. 87. 
III - quanto ao segurado e dependente:

a) pecúlios;

b) serviço social;

c) reabilitação profissional. ${ }^{85}$

Desse modo, os benefícios previstos pelo Regime Geral de Previdência Social - RGPS foram determinados no art. 201 da CRFB/198886, cujo conteúdo determina que a Previdência Social seja organizada sob a forma de um regime geral.

Nesse diapasão, o RGPS rege quais são as características e regras para a concessão dos benefícios previdenciários supracitados.

Cabe ressaltar, ainda, que a aposentadoria é a prestação por excelência da Previdência Social, sobretudo por ter caráter permanente previsto no $§ 7^{\circ}$, do art. 201 da CRFB/198887. Além disso, as aposentadorias por idade, tempo de contribuição e especial, após a concessão pela Previdência Social são irreversíveis e irrenunciáveis por se tratarem de garantias constitucionais.

\subsection{APOSENTADORIAS PROGRAMÁVEIS}

No grupo denominado aposentadorias programáveis, temos: Aposentadoria por Idade, por Tempo de Contribuição, Especial e aos Segurados com Deficiência.

Aposentadoria por Idade: é aquela devida à pessoa quando atinge a idade especificada na lei, podendo ser requerida pelo órgão ou empresa, compulsoriamente. Além disso, apresenta limites de redução nos casos de trabalhadores rurais para aqueles que exercem suas atividades em regime de economia familiar, neste incluídos o produtor rural, o pescador artesanal e o garimpeiro.

Aposentadoria por Tempo de Contribuição: é concedida quando se completa o tempo de contribuição efetivo ao regime previdenciário, respeitadas as regras regulamentadas sobre à matéria, nos termos dos arts. 53 a 63 do Decreto no 3.048/9988, com Redação dada pelo Decreto no 10.410, de 202089. É importante frisar, que todos os segurados do RGPS têm direito à aposentadoria por tempo de contribuição, exceto o segurado especial, o contribuinte individual e o facultativo que optar pela forma estabelecida na Lei Complementar no $123 / 2006^{90}$.

Aposentadoria Especial: espécie da aposentadoria por tempo de contribuição, tem como característica a redução do tempo necessário a inativação, pois sua finalidade é amparar o trabalhador que laborou em atividades nocivas e perigosas à sua saúde, tendo como consequência a redução da contribuição para fins de aposentadoria.

Aposentadoria aos Segurados com Deficiência: embora não expresso no art. 18 da Lei 8.213/9191, a aposentadoria aos segurados com deficiência tem base constitucional no art. 201, §1 ${ }^{\circ}$ da CRFB $/ 88^{92}$. Esse benefício foi originado do art. $3^{\text {o }}$ da Lei complementar no $142 / 2013^{93}$, o Decreto no $^{\circ} 8.145 / 2013^{94}$ e a Lei $13.146 / 2015^{95}$, Estatuto da Pessoa com Deficiência. Como o próprio nome já diz, é um benefício destinado aos segurados que possuem deficiência há pelo menos dois anos. Leva em consideração o grau de

85 Disponível em: http://www.planalto.gov.br/ccivil_03/leis/l8213compilado.htm. Acesso em: 12 de junho de 2019.

86 Disponível em: http://www.planalto.gov.br/ccivil_03/constituicao/constituicao.htm. 12 de junho de 2019.

${ }^{87}$ Idem.

88 Disponível em: http://www.planalto.gov.br/ccivil_03/decreto/d3048compilado.htm. Acesso em: 12 de junho de 2019.

${ }^{89}$ Disponível em: http://www.planalto.gov.br/ccivil_03/_ato2019-2022/2020/decreto/D10410.htm. Acesso em: 12 de junho de 2019.

${ }^{90}$ Disponível em: http://www.planalto.gov.br/ccivil_03/leis/lcp/lcp123.htm. Acesso em: 12 de junho de 2019.

91 Disponível em: http://www.planalto.gov.br/ccivil_03/leis/l8213cons.htm. Acesso em: 12 de junho de 2019.

92 Disponível em: http://www.planalto.gov.br/ccivil_03/constituicao/constituicao.htm. Acesso em: 12 de junho de 2019.

93 Disponível em: http://www.planalto.gov.br/ccivil_03/LEIS/LCP/Lcp142.htm. Acesso em: 12 de junho de 2019.

94 Disponível em: http://www.planalto.gov.br/ccivil_03/_Ato2011-2014/2013/Decreto/D8145.htm. Acesso em: 12 de junho de 2019.

95 Disponível em: http://www.planalto.gov.br/ccivil_03/_ato2015-2018/2015/lei/l13146.htm. Acesso em: 12 de junho de 2019. 
deficiência do segurado, haja vista que aqueles com deficiência grave, podem requerer a aposentadoria ao completarem 25 anos de contribuição, se homem, e 20 anos, se mulher.

\subsection{BENEFÍCIOS POR INCAPACIDADE LABORAL}

O amparo previdenciário em situação de incapacidade laboral corresponde aos benefícios de auxílio doença, aposentadoria por invalidez e o auxílio-acidente.

o Auxílio por Doença trata de benefício concedido ao segurado impedido de trabalhar por doença ou acidente, ou por prescrição médica quando além do período previsto em lei ou a contar da incapacidade temporária.

Já a aposentadoria por invalidez diz respeito à incapacidade do segurado, quando esta for definitiva e total, ou seja, é condicionado ao afastamento de todas as atividades laborativas. Segundo Amado:

[...] em regra, para a concessão deste benefício, será imprescindível que o segurado esteja incapacitado de maneira total e permanente para o exercício do trabalho, bem como não haja possibilidade plausível de ser reabilitado para outra atividade laborativa, compatível com as suas restrições físicas ou psíquicas decorrentes do acidente ou enfermidade. ${ }^{96}$

Por sua vez, o auxílio-acidente trata-se de uma indenização pela perda definitiva da parte da capacidade para o trabalho. De acordo com Castro e Lazzari:

0 auxílio-doença é um benefício previdenciário pago mensalmente ao segurado acidentado como forma de indenização, sem caráter substitutivo do salário, pois é recebido cumulativamente com o mesmo, quando, após, a consolidação das lesões decorrentes de acidente de qualquer natureza - e - não somente de acidentes do trabalho -, resultarem sequelas que impliquem redução da capacidade para o trabalho que habitualmente exercia - Lei n. 8.213/1991, art. 86, caput. ${ }^{97}$

Ademais, há de se mencionar que o auxílio-acidente não é vitalício, devendo o segurado em gozo do benefício se submeter a processo de reabilitação profissional. Maneira pela qual, não cessará o benefício até que seja dado como habilitado para desempenho das atividades exercidas anteriormente, caso contrário poderá ser considerado incapacitado definitivamente para o trabalho, o que o torna apto ao recebimento da aposentadoria por invalidez.

\subsection{BENEFÍCIOS DE PROTEÇÃo À FAMÍLIA E À MATERNIDADE}

Os benefícios de proteção à família e à maternidade são: pensão por morte, auxílio reclusão, saláriomaternidade e salário-família.

A pensão por morte é o benefício pago à família do trabalhador quando ele vem a falecer, nos termos no art. 201, V, da Carta Magna de 198898, bem como nos arts. 74-79 da Lei 8.213/9199. Para concessão de pensão por morte, não há tempo mínimo de contribuição, mas é necessário que o óbito tenha ocorrido enquanto o trabalhador tinha qualidade de segurado, como esclarece a súmula no 416 do Superior Tribunal de Justiça: “É devida a pensão por morte aos dependentes do segurado que, apesar de ter perdido essa qualidade, preencheu os requisitos legais para a obtenção de aposentadoria até a data do seu óbito". 100

O auxílio-reclusão, por seu turno, é um benefício devido aos dependentes do segurado, de baixa renda, recolhido à prisão durante o período em que estiver preso sob regime fechado (sujeito à execução da pena

${ }^{96}$ AMADO, Frederico. Curso de Direito e Processo Previdenciário. 8 ed. Salvador: Ed. Juspodvim, 2016, p. 641.

97 CASTRO, Carlos Alberto Pereira de; LAZZARI, João Batista. Manual de Direito Previdenciário. 20 ed. Rio de Janeiro: Forense, 2017, p. 840.

98 Disponível em: http://www.planalto.gov.br/ccivil_03/constituicao/constituicao.htm. Acesso em: 12 de junho de 2019.

99 Disponível em: http://www.planalto.gov.br/ccivil_03/leis/l8213cons.htm. Acesso em: 12 de junho de 2019.

100 Disponível em: https://www.cjf.jus.br/cjf/outras-noticias/2012-1/dezembro/stj-sumula-direito-de-pensao-pormorte-para-dependentes-de-ex segurado\#: :text=Segundo\%20o\%20que\%20determina $\% 20 \mathrm{a}, \mathrm{a} \% 20 \mathrm{data} \% 20$ do\%20seu\%20\%C3\%B3bito\%E2\%80\%9D. Acesso em: 20 de junho de 2019. 
em estabelecimento de segurança máxima ou média) ou semiaberto (sujeito à execução da pena em colônia agrícola, industrial ou estabelecimento similar). Logo, não cabe concessão de auxílio-reclusão aos dependentes do segurado que estiver em livramento condicional ou cumprindo pena em regime aberto.

Regulamentado nos arts. 71 a 73 da Lei 8.213/91101, o benefício salário maternidade pode ser conceituado nas palavras de Amado como:

O salário maternidade é um benefício previdenciário devido a todas as seguradas do RGPS, sem exceção, que visa substituir a sua remuneração em razão do nascimento do seu filho ou da adoção de uma criança, pois nesse período é preciso que a mulher volte toda sua atenção ao infante, sendo presumida legalmente a sua incapacidade temporária para trabalhar. ${ }^{102}$

Ademais, quanto ao benefício Salário Família esse é utilizado para complementar as despesas domésticas com filhos menores de 14 anos de idade ou inválidos de qualquer idade, conforme regulamenta os arts. 65 a 70 da Lei 8.213/91103, isto é, é um benefício pago aos segurados empregados em razão dos dependentes na respectiva proporção. A despeito dos enteados e tutelados, esses são considerados equiparados desde que não possuam bens suficientes para o próprio sustento, devendo a dependência econômica de ambos ser comprovada.

\subsection{ASSISTÊNCIA SOCIAL}

A Assistência Social está compreendida no conjunto de ações do Estado e da sociedade civil, conforme o art. 194 da Constituição de 1988, regida por lei própria, a Lei 8.742 de $1993^{104}$, tem como objetivo a proteção à família, à maternidade, à infância, à adolescência e à velhice, bem como o amparo às crianças e adolescentes carentes; a promoção da integração ao mercado de trabalho; a habilitação e a reabilitação das pessoas com deficiência e a promoção de sua integração à vida comunitária e a garantia de 1 (um) salário mínimo de benefício mensal à pessoa com deficiência e ao idoso que comprovem não possuir meios de prover a própria manutenção ou de tê-la provida por sua família (art. 2o da Lei 8.742/93105).

Logo, a vertente da Assistência Social tem por finalidade central preencher as lacunas existentes da previdência social, haja vista que esta abrange somente aos que contribuem para o sistema previdenciário ou ainda aqueles elencados a receber a contribuição no sistema, bem como seus dependentes.

Nessa senda, é importante dizer que no tripé da seguridade social (saúde, previdência social e assistência social), a previdência social não é vilã no Estado Democrático de Direito por ser um sistema de benefícios contributivo, haja vista que sua criação foi destinada a servir de base financeira para custear necessidades sociais, sendo autossustentável a partir da contribuição dos beneficiários diretos e indiretos.

Já a Assistência Social tem uma ação além da proteção previdenciária, ela surge para as pessoas que não exercem atividades remuneradas, provendo os mínimos sociais. Conforme entendimento dos autores Castro e Lazzari, a assistência social tem o seguinte conceito:

Assistência social: para idosos e portadores de deficiência, necessidades ou cuidados especiais, abrangendo pessoas que estejam carentes de condições de subsistência, segundo critérios estabelecidos em lei, financiada também pelos contribuintes da Seguridade Social e pelos entes da Federação. ${ }^{106}$

Dessa maneira, a garantia da Assistência Social é dada pelo Benefício de Prestação Continuada da Assistência Social (BPC), o qual é garantido pelo art. 203 da Constituição Federal de $1988^{107}$ é regulamentado pelos Arts. 20 e 21 da Lei no 8.742/1993108, chamada de Lei Orgânica da Assistência Social (Loas), dito isso, vale mencionar que a garantia assistencial é popularmente conhecida como BPC LOAS.

101 Disponível em: http://www.planalto.gov.br/ccivil_03/leis/l8213cons.htm. Acesso em: 12 de junho de 2019. 102 AMADO, Frederico. Curso de Direito e Processo Previdenciário. 8 ed. Salvador: Ed. Juspodvim, 2016, p. 815.

103 Disponível em: http://www.planalto.gov.br/ccivil_03/leis/l8213cons.htm. Acesso em: 12 de junho de 2019.

104 Disponível em: http://www.planalto.gov.br/ccivil_03/leis/l8742.htm. Acesso em: 12 de junho de 2019.

105 Idem.

106 CASTRO, Carlos Alberto Pereira de; LAZZARI, João Batista. Manual de Direito Previdenciário. 20 ed. Rio de Janeiro: Forense, 2017, p. 35.

107 Disponível em: http://www.planalto.gov.br/ccivil_03/constituicao/constituicao.htm. Acesso em: 12 de junho de 2019.

108 Disponível em: http://www.planalto.gov.br/ccivil_03/leis/18742.htm. Acesso em: 12 de junho de 2019. 
Por fim, cumpre ressaltar que, apesar da Previdência Social ainda ter inúmeros desafios a superar, como déficit financeiro, falta de servidores e equipamentos tecnológicos, reduzido número de agências, entre outros, ainda assim, é um meio de segurança aos contributários, uma vez que é com ela que o cidadão, incluindo-se nesse rol o idoso, pode contar em caso de necessidade. Ademais, mesmo aqueles que nunca contribuíram podem se valer da seguridade social por meio de seu viés assistencialista, ou seja, o benefício de prestação continuada.

\section{REFERÊNCIAS}

[1] AMADO, Frederico. Curso de Direito e Processo Previdenciário. 8 ed. Salvador: Juspodvim, 2016.

[2] BRASIL. Presidência da República. Disponível em: http://www.planalto.gov.br. Acesso em: 12 de junho de 2019.

[3] CASTRO, Carlos Alberto Pereira de; LAZZARI, João Batista. Manual de Direito Previdenciário. 20 ed. Rio de Janeiro: Forense, 2017.

[4] JUSTIÇA FEDERAL. Disponível em https://www.cjf.jus.br/cjf/outras-noticias/2012-1/dezembro/stj-sumuladireito-de-pensao-por-morte-para-dependentes-de-ex-

segurado\#: :text=Segundo $\% 20 \mathrm{o} \% 20$ que $\% 20$ determina $\% 20 \mathrm{a}, \mathrm{a} \% 20 \mathrm{data} \% 20$

[5] do\%20seu\%20\%C3\%B3bito\%E2\%80\%9D. Acesso em: 20 de junho de 2019.

[6] SOUZA, Lilian Castro de. Direito Previdenciário - Provas e Concursos. 4 ed. São Paulo: Atlas, 2009. 


\section{Capítulo 4}

\section{As Políticas Públicas}

Dario Amauri Lopes de Almeida

Alciney Januário de Souza

Alex Souza dos Santos Oliveira

Douglas Kanawati Madeira

Flávia C. da Silva Costa

Romeu dos Santos 
Uma política pública pode tanto ser parte de uma política de Estado que é toda política independente do governo e do governante deve ser realizada porque é amparada na Constituição Federal, ou uma política de governo, que é a alternância de poder.

Os direitos sociais previstos no artigo ${ }^{109} 6^{\circ}$ da Constituição Federal Republicana Brasileira, tem a finalidade de assegurar aos desassistidos socialmente, e também combater essas desigualdades impostas pela sociedade de um modo geral, direitos que visam proporcionar uma condição digna em todas as etapas da vida humana.

Com o aumento da expectativa de vida dos brasileiros, surgem políticas direcionadas a atender essa nova demanda, inúmeras leis foram criadas a partir do marco nacional na Constituição Federal Republicana Brasileira/ 1988, procurando direcionar os esforços na busca de atender os mais fragilizados socialmente.

Conforme ensinamentos de José Afonso Silva

Os direitos sociais, como dimensão dos direitos fundamentais do homem, são prestações positivas proporcionadas pelo Estado direta ou indiretamente, enunciadas em normas constitucionais, que possibilitam melhores condições de vida aos mais fracos, direitos que tendem a realizar a igualização de situações sociais desiguais. São, portanto, direitos que se ligam ao direito de igualdade. ${ }^{110}$

Neste contexto, surgem as políticas públicas, direitos sociais previstos na carta magna, mas estes só terão algum resultado positivo, se forem realizados por meio das políticas públicas dos governantes, os quais tem a responsabilidade de elaborar o planejamento, lançar diretrizes e obrigações do poder público com a sociedade, destacando-se a Lei 8.842/94, que trata da política nacional do idoso, o Estatuto do Idoso - Lei $10.741 / 2003$, entre outras.

\section{AS POLÍTICAS PÚBliCAS DESTINADAS AOS IDOSOS NO ÂMBITO DO GOVERNO FEDERAL E AS POLÍTICAS PÚBLICAS EXISTENTES PARA ESSE PÚBLICO EM MANAUS}

\subsection{A AÇÃO DO GOVERNO FEDERAL.}

A Política Nacional de Saúde da Pessoa Idosa - ${ }^{111}$ PNS-PI, instituída pela portaria 2528/GM de 19 de outubro de 2006, busca garantir a atenção adequada e digna para a ${ }^{112}$ população idosa brasileira, visando sua integração. Nessa política estão definidas as diretrizes norteadoras de todas as ações no setor de saúde e indicadas as responsabilidades institucionais para o alcance da proposta. Sua implementação compreende a definição e/ou readequação de planos, programas, projetos e atividades do setor da saúde, direta ou indiretamente relacionados com seu objeto.

A PNSPI tem por objetivo permitir um envelhecimento saudável, o que significa preservar a sua capacidade funcional, sua autonomia e manter o nível de qualidade de vida), em consonância com os princípios e diretrizes do ${ }^{113}$ Sistema Único de Saúde - SUS que direcionam medidas individuais e coletivas em todos os níveis de atenção à saúde. Assim, essa política define diretrizes norteadoras de todas as ações no setor da saúde, com indicação de responsabilidades para o alcance da proposta, como por exemplo:

- Promoção do envelhecimento ativo e saudável;

- Atenção integral e integrada à saúde da pessoa idosa;

- Estímulo às ações intersetoriais, com vistas à integralidade da atenção;

- Implantação de serviços de atenção domiciliar;

- Acolhimento preferencial em unidades de saúde, com respeito ao critério de risco; e,

109 Constituição Federal Republicana do Brasil 1988.

110 SILVA, José Afonso da. Curso de Direito Constitucional Positivo. 27a. edição - São Paulo:Malheiros, 2006, Pag 286.

111 Brasil Secretaria Especial dos Direitos Humanos. Conselho Nacional dos Direitos do Idoso.

112 Organização das Nações Unidas (ONU). Plano de Ação Internacional de Viana sobre Envelhecimento: Relatório da I Assembleia Mundial sobre o Envelhecimento. Viena, Áustria; 1988.

113 Brasil. Ministério da Saúde. Portal da Saúde. 0 que é o Pacto pela Saúde? [Internet]. Brasília; 2011. 
- Provimento de recursos capazes de assegurar qualidade da atenção à saúde da pessoa idosa.

Com o propósito de apresentar as diretrizes e as estratégias e abordar as questões da Política Nacional de Saúde do Idoso, foi possível especificar suas finalidades essenciais propostas para o envelhecimento populacional brasileiro.

A legislação brasileira relativa aos cuidados da população idosa, embora bastante avançada, na prática, ainda é insipiente. Com a vigência do Estatuto do Idoso, na incessante busca em garantir direitos dos idosos e com a ampliação da Estratégia Saúde da Família, tornou-se pública a presença de idosos em famílias fragilizadas, em situação crítica de vulnerabilidade social, o que aponta para a imperiosa readequação da PNSPI. No entanto, essa política veio concretizar um passo importante para a saúde de mais de 11418 milhões de idosos no país, que correspondem a aproximadamente $10,5 \%$ da população brasileira).

\subsection{A AÇÃO DO GOVERNO ESTADUAL E DO GOVERNO MUNICIPAL}

No Amazonas, especificamente em Manaus, as políticas públicas voltadas para a população idosa, basicamente resume-se na Fundação Dr Thomas, onde é desenvolvido o Programa de Atendimento Domiciliar (PADI), criado em setembro de 1997. É um serviço da Prefeitura Municipal de Manaus e caracteriza-se pela realização de visita domiciliar com uma equipe multiprofissional. As visitas são realizadas quando solicitadas através do ${ }^{115}$ Disque Idoso 165 , demanda espontânea e ainda através da Rede de Proteção à Pessoa Idosa.

Outro destaque nessa área, é o ${ }^{116}$ Conselho Municipal do Idoso - CMI -, criado pela Lei no 628, de 8 de novembro de 2001. É um órgão colegiado de caráter consultivo, deliberativo e controlador da política de defesa dos direitos do idoso, veiculado à Fundação Dr. Thomas, responsável pela coordenação e execução da política municipal de defesa dos direitos do idoso.

Especificamente em Manaus, existe uma ${ }^{117}$ Rede de atendimento ao Idoso a saber:

- CIPDI - Centro Integrado de proteção e defesa da pessoa idosa;

- CECI - Centro Estadual de Convivência do Idoso;

- CAIMI João Paulo, Zona Sul;

- DECCI - Delegacia Especializada em crime contra a pessoa idosa;

- Parque Municipal do Idoso;

- Promotoria Especializada na Proteção e Defesa de Direitos;

- PADI - Programa de Atendimento Domiciliar ao Idoso;

- CAIMI Ada Rodrigues Viana- Zona Oeste;

- CEI - Conselho Estadual do Idoso; e,

- CREAS Nossa Senhora das Graças.

\section{ALGUMAS CONSIDERAÇÕES CONCLUSIVAS}

Na pesquisa do presente tema, longe de estar esgotado, encontrou-se a existência de uma legislação ideal para tratar da questão saúde do idoso, mas a insipiência de alguns serviços que não são ofertados, permite

114 Instituto Brasileiro de Geografia e Estatística (IBGE). Censo demográfico: sinopse dos resultados do Censo 2010 [Internet]. Rio de Janeiro; 2010.

115 Prefeitura Municipal de Manaus. Disponível em: http://www.manaus.am.gov.br/ Acesso em: 10 de setembro de 2019.

116 Prefeitura Municipal de Manaus. Disponível em: http://www.manaus.am.gov.br/ Acesso em: 10 de setembro de 2019.

117 Governo do Estado do Amazonas e Prefeitura Municipal de Manaus. Disponível em: http://www.manaus.am.gov.br/ Acesso em: 10 de setembro de 2019. 
a criação de lacunas, que necessariamente precisaram ser objetos de estudos para reorganização do que está disponível.

A população idosa, a sociedade e os administradores nas várias esferas de governo necessitam de um diálogo permanente, pensar a longo prazo na questão, atender a uma demanda da sociedade representada por seus idosos, questão está que exige uma resposta em um curto espaço de tempo, visando a continuidade dos serviços de saúde e o bem-estar ao alcance dos idosos.

No momento em que o Estado, independente da esfera, quer seja municipal, estadual, distrital ou federal, deixa de cumprir com seu dever legal de acesso aos serviços essenciais à saúde e o bem-estar da população, independentemente da faixa etária, abre o precedente para que as necessidades de serviços dessa população sejam discutidas, definidas e determinadas no âmbito do judiciário brasileiro.

Tal judicialização, expressa a incompetência, a incapacidade do Estado em assegurar a todos os cidadãos, os direitos que lhe são devidos e reconhecidos em lei.

\section{REFERÊNCIAS}

[1] BRASIL. Constituição da República Federativa do Brasil De 1988

[2] SILVA, José Afonso da. Curso de Direito Constitucional Positivo. 27a. edição - São Paulo:Malheiros, 2006, Pag 286.

[3] BRASIL, Secretaria Especial dos Direitos Humanos. Conselho Nacional dos Direitos do Idoso. Disponível em: https://www.gov.br/mdh/pt-br/ Acesso em 10 de setembro de 2019.

[4] ORGANIZAÇÃO das Nações Unidas (ONU). Plano de Ação Internacional de Viana sobre Envelhecimento: Relatório da I Assembleia Mundial sobre o Envelhecimento. Viena, Áustria; 1988. Disponível em: https://nacoesunidas.org/acao/pessoas-idosas/; Acesso em 08 de setembro de 2019.

[5] BRASIL. Ministério da Saúde. Portal da Saúde. O que é o Pacto pela saúde? [Internet]. Brasília; 2011. Disponível em: http://conselho.saude.gov.br Acesso em 08 de setembro de 2019.

[6] BRASIL .Instituto Brasileiro de Geografia e Estatística (IBGE). Censo demográfico: sinopse dos resultados do Censo 2010 [Internet]. Rio de Janeiro; 2010. Disponível em: https://censo2010.ibge.gov.br/resultados.html Acesso em 05 de setembro de 2019.

[7] MANAUS. Prefeitura Municipal de Manaus. Disponível em: http://www.manaus.am.gov.br/ Acesso em: 10 de setembro de 2019.

[8] AMAZONAS. Governo do Estado do Amazonas. Disponível em: http://www.manaus.am.gov.br/ Acesso em: 10 de setembro de 2019 . 


\section{Capítulo 5}

\section{A judicialização do direito à saúde do Idoso}

Renzzo Fonseca Romano

Luciana Beatriz Pinto Campelo

Maira de Souza Pontes 


\section{ACESSO À JUSTIÇA E JUDICIALIZAÇ̃̃o DA SAÚDE}

Em busca de medicamentos, insumos e tratamentos médicos, o número de ações judiciais tem crescido expressivamente a fim de efetivar o direito fundamental à saúde previsto no art. 196 na Constituição Federal, diante da falta de políticas públicas eficazes.

Dentre os grupos sociais que demandam a efetivação do direito à saúde, os idosos configuram parcela da população vulnerável que se vale de demandas judiciais, a fim de que a jurisdição ordene, pela via da decisão judicial, que Administração Pública cumpra a Constituição e, em nível, infraconstitucional, o Estatuto do Idoso.

Nesse contexto, o fenômeno da "Judicialização da Saúde", que BARROSO (2011) apud CIRICO et al118 definem como uma transferência de poder para as instituições judiciais em detrimento das instâncias políticas a configurar uma mudança drástica no modo de pensar e de se praticar o direito no mundo romano-germânico.

Com efeito, o direito à saúde se caracteriza como um direito público subjetivo e direito fundamental social, legitimado por meio de políticas públicas e/ou programas de "ação social", com alicerce nos princípios da igualdade e universalidade.

Por estarem incluídos no rol dos direitos fundamentais, os direitos sociais têm aplicabilidade imediata, neste sentido, assevera Ieda Tatiana Cury ${ }^{119}$ que em quase todos os sistemas jurídicos prevalecia até então a noção de que apenas os direitos de liberdade eram de aplicabilidade imediata, ao passo que os direitos sociais tinham aplicabilidade mediata.

Portanto, em um Estado Democrático de Direito, não se pode esperar que as responsabilidades na criação e destinação de recursos para políticas públicas voltadas para saúde sejam assumidas pelos juízes, considerando a separação das funções do poder prevista o art. 5, II, da Constituição Federal.

Entretanto, ante a ausência de políticas públicas adequadas e considerando a obrigatoriedade da resposta judicial, que jamais pode negar a jurisdição (non liquet), o Judiciário vem sendo excessivamente demandado e provocado a dar resposta sobre as mais variadas formas de acesso ao direito fundamental à saúde que, na prática, são negadas aos cidadãos e especialmente aos vulneráveis idosos, parcela crescente da população brasileira.

Diante da ineficácia da prestação dos serviços de saúde constitucionalmente garantidos, a judicialização do direito à saúde do idoso é, portanto, direcionada a diversos serviços públicos e privados, como o fornecimento de medicamentos, a disponibilização de exames e a cobertura de tratamentos para doenças, além de situações que envolvem questões contratuais com os seguros e planos de saúde, por isso, segundo BAHIA, Alexandre et al ${ }^{120}$, o cidadão recorre à tutela jurisdicional para exercer seu direito fundamental à saúde, diante da recusa administrativa.

Embora não haja estudos específicos sobre a judicialização da saúde do idoso, o Conselho Nacional de Justiça - CNJ e o Ministério da Saúde têm produzido estatísticas relevantes sobre o tema em geral da judicialização da saúde.

\section{A JUDICIALIZAÇÃO DA SAÚDE NA VISÃO DOS TRIBUNAIS BRASILEIROS}

Segundo notícia divulgada pelo Ministério da Saúde ${ }^{121}$, em 2017, foi destinado R\$1,02 bilhão para aquisição de medicamentos e tratamentos exigidos por demandas judiciais. Do total de gastos em 2017, 11 (onze) medicamentos correspondem a 92\% do valor, ou seja, $\mathrm{R} \$ 965,2$ milhões.

Entre eles estão Soliris (eculizumabe), Vimizim (elosulfase), Translarna (Atalureno) 1000mg e $250 \mathrm{mg}$, Juxtapid (lomitapida), Replagal (alfagalsidase), Cinryze (Inibidor de C1 esterase), Myalept (Metreleptina).

\footnotetext{
${ }^{118}$ CIRICO, Priscila Freitas; RESNER, Andrea Aparecida Ribeiro e RACHED, Chennyfer Dobbins Abi. Os impactos da Judicialização na saúde suplementar. Revista Gestão em Foco. Edição no 11, 2019, p. 6.

119 CURY, Ieda Tatiana. Direito Fundamental à saúde: Evolução, Normatização e Efetividade. 8ª ed., Rio de Janeiro: Lumen Juris, 2005, p. 14.

${ }^{120}$ BAHIA, Alexandre, BACHA e SILVA, Diogo, et al. Processo e constituição: estudos sobre judicialização da saúde, da educação e dos direitos homoafetivos. Rio de Janeiro, 2015, p. 311.

121 Disponível em: http://www.saude.gov.br/noticias/agencia-saude/43910-judicializacao-da-saude-no-brasil-etema-de-debate-com-autoridade: acesso em 18 de setembro de 2019.
} 
De acordo com o Tribunal de Justiça do estão de São Paulo ${ }^{122}$ - Secretaria Judiciária, entre os anos de 2017 e 2018 foram julgados mais de 40 mil casos tendo como objeto a saúde. Na Seção de Direito Público, foram julgados 14 mil recursos, quase 10 mil deles se referiam a pedidos de medicamento, tema que em 2017 ocupou o quinto lugar entre as maiores demandas da seção e em 2016 alcançaram o terceiro lugar dentre os assuntos mais debatidos.

Noutro giro, a Seção de Direito Privado, do referido Tribunal de Justiça, realizou no ano de 2017 mais de 25 mil julgamentos referentes a planos de saúde, que alcançaram o primeiro lugar entre as demandas mais julgados, à frente de processos sobre contratos bancários e promessas de compra e venda de imóveis.

A maioria das ações da área de saúde que chega à Seção de Direito Público, como pedidos de tratamentos, medicamentos e ressarcimento por procedimentos que não são oferecidos pelo SUS é julgada favoravelmente aos demandantes, conforme exposto no sítio eletrônico daquele Tribunal.

Nos tribunais superiores, os temas relativos ao direito à saúde, especialmente no STJ versam sobre o reajuste da mensalidade do plano de saúde fundado em mudança de faixa etária (RESp 1.568.244/RJ; Tema 952), a legitimidade ad causam do Ministério Público em demandas de saúde propostas contra os entes federativos (RESp 1.682.836/SP; Tema 966) e a obrigatoriedade do fornecimento de medicamento não registrados pela ANVISA pelas operadoras de plano de saúde (RESp 1726563 e 1712163).123

No âmbito do Supremo Tribunal Federal - STF, tamanha a importância do tema relativo ao direito à saúde do idoso, reconheceu a existência de repercussão geral quanto à aplicação do Estatuto do Idoso em contratos de plano de saúde firmados antes de sua vigência. Nesse sentido, o Tribunal discutiu a aplicabilidade ou não da Lei 10.741/2003 a contratos de plano de saúde firmados antes da sua vigência, Tema de repercussão geral n. 381, ainda pendente de julgamento. ${ }^{124}$

\subsection{OS NÚMEROS DA JUDICIALIZAÇÃO SOBRE SAÚDE NO BRASIL}

De acordo com o Relatório Analítico da Série Justiça Pesquisa do CNJ125, as decisões judiciais de segunda instância em matéria de direito à saúde contam com um total de 164.587 acórdãos por tribunal, dados esses que podem ser analisados conforme tabela abaixo:

\begin{tabular}{|c|c|c|}
\hline Tribunal & Número de Acórdãos & $\%$ \\
\hline TJSP & 80.355 & $48,82 \%$ \\
\hline TJRS & 33.131 & $20,13 \%$ \\
\hline TJPR & 9.193 & $5,59 \%$ \\
\hline TJRJ & 5.502 & $3,34 \%$ \\
\hline TJDF & 3.193 & $1,94 \%$ \\
\hline TJRN & 2.364 & $1,44 \%$ \\
\hline TJPB & 1.837 & $1,12 \%$ \\
\hline TJPA & 1.656 & $1,01 \%$ \\
\hline TJAL & 1.519 & $0,92 \%$ \\
\hline TJCE & 1.273 & $0,77 \%$ \\
\hline TJSC & 1.102 & $0,67 \%$ \\
\hline TJES & 1.008 & $0,61 \%$ \\
\hline TJMG & 583 & $0,35 \%$ \\
\hline TJMS & 463 & $2,81 \%$ \\
\hline TJMT & 399 & $0,24 \%$ \\
\hline TJAC & 384 & $0,23 \%$ \\
\hline TJBA & 356 & $0,22 \%$ \\
\hline TJAM & 261 & $0,16 \%$ \\
\hline TJRO & 44 & $0,03 \%$ \\
\hline TJPI & 33 & $0,02 \%$ \\
\hline
\end{tabular}

\footnotetext{
122 Disponível em: http://www.tjsp.jus.br/ Acesso em: 18 de setembro de 2019

123 Disponível em: http://www.stj.jus.br/repetitivos/temas_repetitivos/pesquisa.jsp?\&l=1\&i=952\&tt=T. Acesso em: 30 de maio de 2019

${ }^{124}$ Disponível em: http://www.stf.jus.br/portal/jurisprudenciaRepercussao/verAndamentoProcesso.asp?incidente= 3959903\&numeroProcesso=630852\&classeProcesso=RE\&numeroTema=381. Acesso em: 30 de junho de 2020.

125 Disponível em: https://static.poder360.com.br/2019/03/relatorio-judicializacao-saude-Insper-CNJ.pdf Acesso em: 18 de setembro de 2019
} 
(continuação ...)

\begin{tabular}{|c|c|c|}
\hline Tribunal & Número de Acórdãos & $\%$ \\
\hline TJRR & 21 & $0,01 \%$ \\
\hline TRF4 & 15.731 & $9,56 \%$ \\
\hline TRF1 & 9 & $0,01 \%$ \\
\hline TRF5 & 3 & $0,00 \%$ \\
\hline TOTAL: & 164.587 & $100 \%$ \\
\hline
\end{tabular}

Acórdãos classificados como Judicialização da Saúde por Tribunal

Segundo o referido demonstrativo, o Estado de São Paulo (TJSP) julgou mais de oitenta mil acórdãos sobre judicialização da saúde, o que corresponde a quase $50 \%$ de um total de aproximadamente 165 mil acórdãos julgados. No entanto, no decorrer dos anos, pode ser verificada, por meio das imagens abaixo, que a incidência dessas demandas relacionadas à saúde era diferente entre as regiões.

No âmbito dessa pesquisa foram criadas duas espécies de indicadores de intensidade de judicialização da saúde por tribunal e por anos obtidos por meio de dados de gestão processual, dados demográficos e de judicialização em geral, constante no Relatório Justiça em Números.

0 primeiro indica o número de ações judiciais relativas à saúde em proporção à população da jurisdição (número de ações por 100 mil habitantes). 0 propósito é revelar a importância da litigância em saúde para uma determinada população. 0 segundo, por sua vez, informa a proporção de casos relacionados à judicialização da saúde em relação ao total de processos que tramitaram no 1oㅡ grau, Juizados Especiais e Turmas Recursais. Este indicador revela o quão importante em termos quantitativos é a judicialização da saúde dentro do Judiciário. Senão, vejamos:

\begin{tabular}{|c|c|c|c|c|c|c|c|c|c|c|c|}
\hline Tכ & REGIÃo & 2009 & 2010 & 2011 & 2012 & 2013 & 2014 & 2015 & 2016 & 2017 & MÉDIA \\
\hline TJMS & Centro-Oeste & 2,16 & 28,62 & 47,95 & 79,28 & 112,40 & 154,45 & 148,61 & 211,90 & 214,70 & 111,12 \\
\hline TJCE & Nordeste & 11,29 & 10,72 & 15,86 & 28,00 & 46,55 & 52,63 & 165,75 & 65,19 & 310,68 & 78,52 \\
\hline TJRN & Nordeste & 44,38 & 66,47 & 78,75 & 76,95 & 74,51 & 82,47 & 72,13 & 77,64 & 116,68 & 76,67 \\
\hline TJPE & Nordeste & 25,48 & 28,13 & 36,61 & 92,13 & 132,55 & 59,62 & 53,94 & 63,88 & 66,09 & 62,05 \\
\hline TJMT & Centro-Oeste & 66,12 & 77,85 & 64,86 & 72,61 & 67,60 & 83,02 & 46,18 & 45,23 & 33,58 & 61,89 \\
\hline TJSC & sul & 3,76 & 6,21 & 7,68 & 14,08 & 29,69 & 67,80 & 102,80 & 121,37 & 175,73 & 58,79 \\
\hline TJAL & Nordeste & 14,13 & 38,35 & 35,09 & 60,94 & 35,41 & 19,27 & 48,58 & 87,38 & 85,05 & 47,13 \\
\hline TJMA & Nordeste & 34,16 & 62,50 & 62,51 & 51,20 & 34,66 & 37,79 & 31,66 & 32,18 & 34,44 & 42,34 \\
\hline TJSP & Sudeste & 9,08 & 18,74 & 22,55 & 33,46 & 37,86 & 44,57 & 48,47 & 47,72 & 52,03 & 34,94 \\
\hline TJRO & Norte & 0,00 & 11,53 & 14,34 & 36,41 & 71,23 & 17,61 & 25,73 & 0,17 & 0,00 & 19,67 \\
\hline тנто & Norte & 0,07 & 0,29 & 3,00 & 7,27 & 12,18 & 16,97 & 31,09 & 38,10 & 38,70 & 16,41 \\
\hline TRJ & Sudeste & 114,98 & 24,72 & 0,14 & 0,09 & 0,25 & 0,70 & 1,10 & 0,73 & 1,03 & 15,97 \\
\hline TJAC & Norte & 0,00 & 0,41 & 1,21 & 5,80 & 14,94 & 27,46 & 21,78 & 31,47 & 32,06 & 15,01 \\
\hline TJDFT & Centro-oeste & 0,00 & 0,04 & 0,11 & 0,38 & 0,93 & 1,54 & 4,67 & 19,65 & 87,61 & 12,77 \\
\hline TJMG & Sudeste & 1,92 & 3,20 & 3,86 & 5,84 & 8,92 & 9,64 & 10,87 & 17,26 & 26,26 & 9,75 \\
\hline IPI & Nordeste & 0,22 & 0,22 & 0,22 & 0,38 & 0,72 & 1,25 & 2,09 & 1,28 & 1,89 & 0,92 \\
\hline TJES & Sudeste & 0,09 & 0,23 & 0,25 & 0,28 & 0,81 & 0,62 & 0,79 & 1,16 & 1,67 & 0,65 \\
\hline Total & & 24,40 & 20,34 & 19,97 & 29,59 & 35,71 & 35,95 & 45,41 & 43,68 & 67,04 & 35,79 \\
\hline
\end{tabular}

Número de processos judiciais relativos à Saúde (LAI) 35 a cada 100 mil habitantes com base em dados coletados (número de processos relativos à Saúde por UF mais dados da Justiça em números). 


\begin{tabular}{|c|c|c|c|c|c|c|c|c|c|c|}
\hline TJ & REGIÃO & 2009 & 2010 & 2011 & 2012 & 2013 & 2014 & 2015 & 2016 & 2017 \\
\hline TJAC & Norte & $0,000 \%$ & $0,002 \%$ & $0,005 \%$ & $0,023 \%$ & $0,060 \%$ & $0,129 \%$ & $0,098 \%$ & $0,150 \%$ & $0,145 \%$ \\
\hline TJAL & Nordeste & $0,070 \%$ & $0,178 \%$ & $0,170 \%$ & $0,293 \%$ & $0,179 \%$ & $0,100 \%$ & $0,260 \%$ & $0,455 \%$ & $0,399 \%$ \\
\hline TJCE & Nordeste & $0,071 \%$ & $0,075 \%$ & $0,109 \%$ & $0,173 \%$ & $0,274 \%$ & $0,298 \%$ & $1,000 \%$ & $0,406 \%$ & $1,927 \%$ \\
\hline TJDF & $\begin{array}{l}\text { Centro } \\
\text {-oeste }\end{array}$ & $0,000 \%$ & $0,000 \%$ & $0,000 \%$ & $0,001 \%$ & $0,003 \%$ & $0,005 \%$ & $0,014 \%$ & $0,055 \%$ & $0,268 \%$ \\
\hline TJES & Sudeste & $0,000 \%$ & $0,001 \%$ & $0,001 \%$ & $0,001 \%$ & $0,002 \%$ & $0,002 \%$ & $0,002 \%$ & $0,003 \%$ & $0,005 \%$ \\
\hline TJMA & Nordeste & $0,668 \%$ & $1,102 \%$ & $0,617 \%$ & $0,440 \%$ & $0,252 \%$ & $0,203 \%$ & $0,162 \%$ & $0,149 \%$ & $0,151 \%$ \\
\hline TJMG & Sudeste & $0,009 \%$ & $0,013 \%$ & $0,016 \%$ & $0,023 \%$ & $0,035 \%$ & $0,036 \%$ & $0,042 \%$ & $0,065 \%$ & $0,101 \%$ \\
\hline TJMS & $\begin{array}{l}\text { Centro } \\
\text { - oeste } \\
\end{array}$ & $0,005 \%$ & $0,079 \%$ & $0,142 \%$ & $0,230 \%$ & $0,380 \%$ & $0,593 \%$ & $0,381 \%$ & $0,528 \%$ & $0,512 \%$ \\
\hline TMT & $\begin{array}{l}\text { Cente } \\
\text { - oeste }\end{array}$ & $0,226 \%$ & $0,245 \%$ & $0,191 \%$ & $0,204 \%$ & $0,180 \%$ & $0,214 \%$ & $0,110 \%$ & $0,102 \%$ & $0,076 \%$ \\
\hline TJPE & Nordeste & $0,081 \%$ & $0,096 \%$ & $0,131 \%$ & $0,335 \%$ & $0,531 \%$ & $0,258 \%$ & $0,220 \%$ & $0,246 \%$ & $0,250 \%$ \\
\hline TJPI & Nordeste & $0,002 \%$ & $0,002 \%$ & $0,002 \%$ & $0,003 \%$ & $0,004 \%$ & $0,006 \%$ & $0,011 \%$ & $0,006 \%$ & $0,009 \%$ \\
\hline TJRJ & Sudeste & $0,182 \%$ & $0,043 \%$ & $0,000 \%$ & $0,000 \%$ & $0,000 \%$ & $0,001 \%$ & $0,001 \%$ & $0,001 \%$ & $0,001 \%$ \\
\hline TJRN & Nordeste & $0,278 \%$ & $0,454 \%$ & $0,455 \%$ & $0,388 \%$ & $0,388 \%$ & $0,387 \%$ & $0,316 \%$ & $0,319 \%$ & $0,553 \%$ \\
\hline TJRO & Norte & $0,000 \%$ & $0,045 \%$ & $0,050 \%$ & $0,121 \%$ & $0,243 \%$ & $0,061 \%$ & $0,095 \%$ & $0,001 \%$ & $0,000 \%$ \\
\hline TJSC & sul & $0,009 \%$ & $0,015 \%$ & $0,018 \%$ & $0,032 \%$ & $0,068 \%$ & $0,161 \%$ & $0,224 \%$ & $0,220 \%$ & $0,317 \%$ \\
\hline TSP & Sudeste & $0,017 \%$ & $0,035 \%$ & $0,041 \%$ & $0,059 \%$ & $0,069 \%$ & $0,082 \%$ & $0,088 \%$ & $0,086 \%$ & $0,093 \%$ \\
\hline TJTO & Norte & $0,000 \%$ & $0,001 \%$ & $0,011 \%$ & $0,026 \%$ & $0,044 \%$ & $0,064 \%$ & $0,121 \%$ & $0,138 \%$ & $0,140 \%$ \\
\hline Total & & $0,065 \%$ & $0,054 \%$ & $0,051 \%$ & $0,074 \%$ & $0,088 \%$ & $0,087 \%$ & $0,108 \%$ & $0,102 \%$ & $0,155 \%$ \\
\hline
\end{tabular}

Representatividade dos processos judiciais relativos à Saúde (LAI) em relação ao total de processos de 1ograu, Juizados Especiais e Turmas Especiais.

Observa-se que há grande variabilidade entre tribunais. O Estado de São Paulo, muitas vezes referenciado como um espaço de elevada litigiosidade, tem um indicador médio ligeiramente inferior à média dos estados brasileiros que compõem a base de dados de saúde em 1a instância: enquanto São Paulo apresenta cerca de 35 casos para cada 100 mil habitantes, a média é 36 casos a cada 100 mil habitantes.

Esse é um dado importante a ser destacado, pois contraria o senso comum, em parte construído pela própria literatura, de que alguns estados do Sul e Sudeste são os que apresentam maior judicialização.

Em termos per capita, o índice regional de judicialização demonstra que não são esses os casos com maior volume de ações judiciais em saúde. Os cinco primeiros com maior índice são estados das regiões CentroOeste e Nordeste: Mato Grosso do Sul, Ceará, Rio Grande do Norte à época analisada. Já no que diz respeito aos assuntos mais relevantes, discutidos nos tribunais, merece maior evidência os assuntos "planos de saúde", "seguro" e "saúde", propriamente dita, tanto em primeira instância quanto em segunda, conforme pode ser identificado nos gráficos abaixo. Os demais tópicos abordados em processos judiciais são tratamento hospitalar, fornecimento de medicamentos, serviços hospitalares, entre outros.

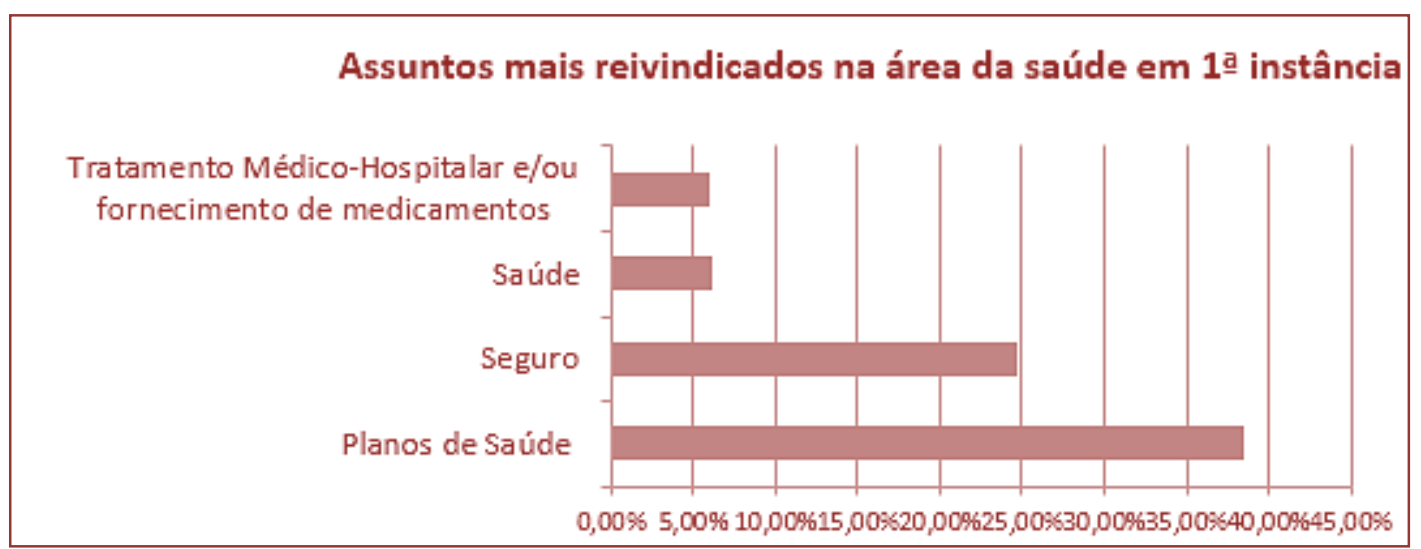


Os quatro assuntos mais tratados em processos relativos à saúde em tramitação e já concluídos/arquivados, conforme informado pelos tribunais por meio da LAI.

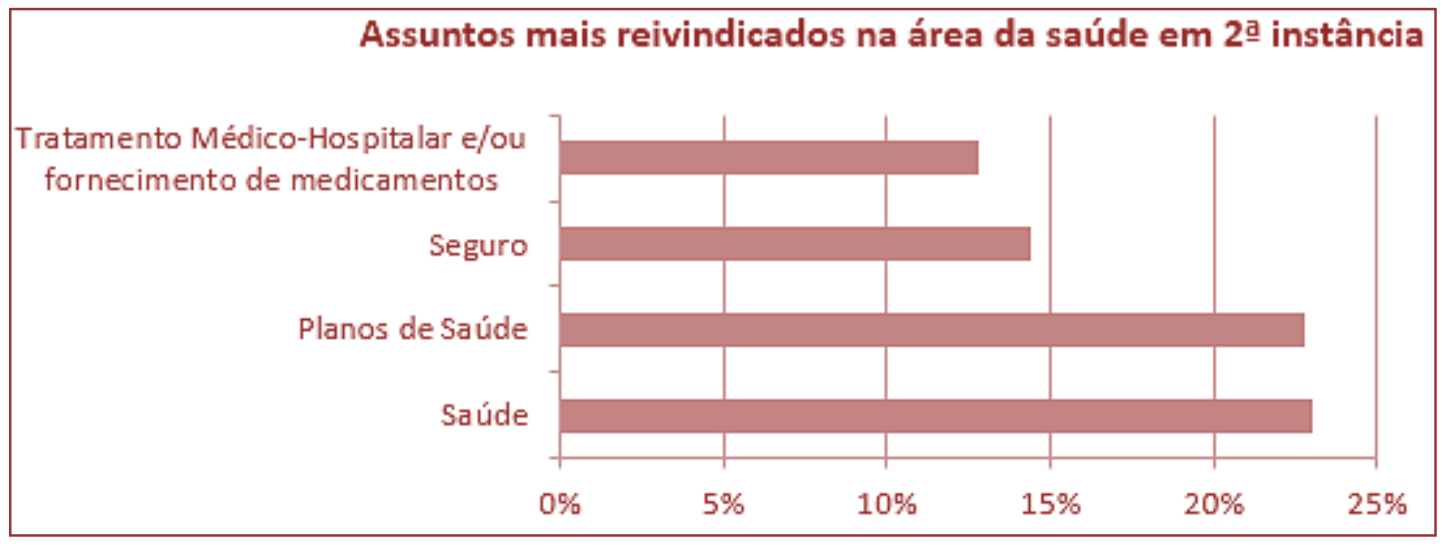

Diante dos dados expostos, percebe-se que os principais temas enfrentados pelos tribunais em segunda instância não necessariamente são os mais distribuídos em primeira instância, mesmo considerando que a base de dados cobre um período relativamente extenso (10 anos). Observa-se, portanto, que há, aparentemente, uma certa concentração de assunto no que se refere a recursos judiciais.

\subsection{DEMANDAS INDIVIDUAIS E COLETIVAS}

No século XIX, o Direito buscava a consolidação e proteção dos interesses individuais com o foco no sujeito de direitos, incluindo a proteção do direito à vida, ao corpo, à saúde e à liberdade. Havia grande preocupação com a proteção da personalidade e o desenvolvimento legislativo concentrava-se na proteção do indivíduo e no respeito máximo às declarações de vontade, fazendo prevalecer o pacta sunt servanda.

Tal situação social foi superada a partir do século XX, oportunidade em que a sociedade moderna passou a se caracterizar por alterações substanciais promovidas pelos avanços tecnológicos e a consequente massificação dos fatos sociais. Massificou-se o consumo, as relações comerciais, os danos ambientais, as relações jurídicas como um todo e, em consequência, massificaram-se os conflitos.

Houve, então, a necessidade de se tutelar os novos direitos, que transcendiam a individualidade do modelo processual do século anterior. Nesse contexto, verifica-se um conjunto de inovações na ordem jurídicoprocessual, alargando-se o rol de direitos tutelados, somando-se aos direitos individuais e sociais aqueles vinculados à sociedade contemporânea globalizada, surgindo o veio a ser denominado, por sua natureza, de direitos transindividuais.

No que tange o diploma Processual Civil, enquanto nas demandas individuais repetitivas a legitimidade é ordinária, posto que o direito material objeto da tutela jurisdicional é de cunho individual, nas ações voltadas aos direitos transindividuais e coletivos, a legitimidade é essencialmente extraordinária porque o direito material não se titulariza em um indivíduo, mas sim em uma coletividade ou em um grupo indeterminado de titulares, como expõe NOGUEIRA ${ }^{126}$ :

"A solução então de várias demandas individuais é feita - como visto de forma otimizada - através da seleção de um ou mais casos representativos da controvérsia, de modo que a solução adotada para o caso escolhido (a fundamentação, a ratio decidendi ou tese jurídica) será apenas transplantada para as demais demandas individuais que versarem sobre o mesmo tema, mas não haverá coisa julgada extensiva àqueles que não são partes nas demandas."

No tocante à judicialização da saúde, os tribunais e juízes são em sua maioria demandados por meio de casos individuais e a procedência dos pedidos formulados nas demandas tendem a provocar a necessidade de realização de reformas estruturais sobre a política pública de saúde via ações coletivas.

126 NOGUEIRA, Gustavo. A coletivização das demandas individuais no NCPC e sua convivência com as demandas coletivas. Revista de Processo, 2016, p. 6. 
No entanto, ainda há a prevalência de demandas individuais que geram um processo de subjetivação do direito à saúde. De acordo com o Relatório Analítico do CNJ apontado, já exposto, essa dicotomia de análise, tanto sobre a órbita individual quanto coletiva, foi averiguada sobre duas vertentes:

A primeira investiga algumas características descritivas das ações coletivas e seus resultados, procurando identificar diferenças regionais e entre instâncias. A segunda procura testar a hipótese de que juízes tenderiam a ser mais favoráveis ao demandante em ações individuais, utilizando, para tanto, um modelo probit, em que se avalia a probabilidade de sucesso da demanda em função das características do caso.

No que se refere a pedidos de tutela provisória de urgência antecipada, apenas uma pequena parcela das ações que compõem o banco são ações coletivas: 3,62\% das ações citam os termos "ação coletiva", "ação civil pública" ou "mandado de segurança coletivo", conforme a imagem abaixo:

Casos de Tutela Antecipada

\begin{tabular}{|c|c|c|c|}
\hline TRIBUNAL & $N^{\circ}$ CASOS TJ & $\begin{array}{c}N^{\circ} \text { CASOS AÇÕES } \\
\text { COLETIVAS }\end{array}$ & $\begin{array}{l}\text { \% AçÖES } \\
\text { COLETIVAS }\end{array}$ \\
\hline TAC & 98 & 8 & $8,16 \%$ \\
\hline TJAL & 4.269 & 528 & $12,37 \%$ \\
\hline TJAM & 1.358 & 12 & $0,88 \%$ \\
\hline TJCE & 67 & 2 & $2,99 \%$ \\
\hline TJGO & 4 & 0 & $0,00 \%$ \\
\hline TJMT & 833 & 13 & $1,56 \%$ \\
\hline TJPB & 123 & - & - \\
\hline TJPE & 7.933 & 121 & $1,53 \%$ \\
\hline TJPI & 411 & 6 & $1,46 \%$ \\
\hline TJRN & 3.120 & 32 & $1,03 \%$ \\
\hline TJRR & 50 & 0 & $0,00 \%$ \\
\hline TSC & 6.271 & 353 & $5,63 \%$ \\
\hline TJSE & 2 & - & - \\
\hline TJSP & 5.301 & 42 & $0,79 \%$ \\
\hline TנTO & 212 & 8 & $3,77 \%$ \\
\hline TJRF1 & 95 & - & - \\
\hline TJTRF3 & 822 & - & - \\
\hline TTRF4 & 125 & - & - \\
\hline Total & 31.094 & 1126 & $3,62 \%$ \\
\hline
\end{tabular}

Para a segunda instância, os dados de ações coletivas totalizam 2,35\% dos casos com os termos "ação coletiva", "ação civil pública" ou "mandado de segurança coletivo", sendo este um bom indicativo do baixo número de ações coletivas no número de ações que compõem o banco de dados, como segue: 
Casos da $2^{\text {a }}$ Instância por Tribunal

\begin{tabular}{|c|c|c|c|}
\hline TRIBU NAL & $\begin{array}{l}\text { N' CASOS } \\
\text { NOTJ }\end{array}$ & $\begin{array}{l}N^{\circ} \text { CASOS AÇOES } \\
\text { COLETIVÁS }\end{array}$ & $\begin{array}{l}\text { \% AÇס̄ES } \\
\text { COLETIVAS }\end{array}$ \\
\hline TJAC & 384 & 4 & $1,04 \%$ \\
\hline TJAL & 1.519 & 4 & $0,26 \%$ \\
\hline TJAM & 261 & 4 & $1,53 \%$ \\
\hline TUBA & 356 & 18 & $5,06 \%$ \\
\hline UCE & 1.273 & 1 & $0,08 \%$ \\
\hline TJDF & 3.193 & 14 & $0,44 \%$ \\
\hline TJES & 1.008 & $\mathbf{o}$ & $0,00 \%$ \\
\hline TJMG & 583 & 53 & $9,09 \%$ \\
\hline TJMS & 4.630 & 6 & $0,13 \%$ \\
\hline TUMT & 399 & 63 & $15,79 \%$ \\
\hline TJPA & 1.656 & 425 & $25,66 \%$ \\
\hline TJPB & 1.837 & 160 & $8,71 \%$ \\
\hline TPI & 33 & 0 & $0,00 \%$ \\
\hline TJPR & 9.193 & 33 & $0,36 \%$ \\
\hline TUR & 5.502 & 7 & $0,13 \%$ \\
\hline TURN & 2.364 & 144 & $6,09 \%$ \\
\hline TJRO & 44 & 8 & $18,18 \%$ \\
\hline TJRR & 21 & 0 & $0,00 \%$ \\
\hline TJRS & 33.131 & 146 & $0,44 \%$ \\
\hline TSSC & 1.102 & 72 & $6,53 \%$ \\
\hline TSSP & 80.355 & 2298 & $2,86 \%$ \\
\hline TRF1 & 9 & 0 & $0,00 \%$ \\
\hline TRF4 & 15.731 & 404 & $2,57 \%$ \\
\hline TRF5 & 3 & 0 & $0,00 \%$ \\
\hline Total & 164587 & 3868 & $2,35 \%$ \\
\hline
\end{tabular}

Verifica-se que ações coletivas se apresentam associadas a uma maior probabilidade de sucesso das demandas judiciais. Isso ocorre em virtude de as ações coletivas serem mais raras e só são ajuizadas quando os atores que a iniciam conhecem sua adequação ao caso e suas chances de sucesso - enfim, as ações coletivas estariam sendo utilizadas com mais parcimônia, nos casos para os quais realmente são cabíveis.

No entanto, a concessão de tutelas provisórias de urgência nas ações coletivas ainda representa um baixo percentual, no contexto do total das ações em primeira ou em segunda instâncias, porém isso não é suficiente para testar a hipótese de que ações coletivas têm menores chances de sucesso do que as individuais.

Destarte, a melhor forma de tutela dos direitos é a conjunção através dos variados sistemas processuais, de modo que o desenvolvimento da tutela coletiva não irá prejudicar a tutela individual. Ao contrário, o sistema judicial se fortalece, na medida em que consegue dar tratamento especial a cada tipo de direito, evitando, diante do desenvolvimento do processo coletivo, inúmeras ações individuais, o que, sem dúvida, leva a uma melhoria qualitativa da função jurisdicional.

\section{CONSEQUÊNCIAS DO EXCESSO DE JUDICIALIZAÇÃO - A HIPÓTESE DA DESJUDICIALIZAÇÃO}

O principal prejuízo do excesso de judicialização é a sobrecarga do Poder Judiciário sobre matéria que, em tese, deveriam ser solucionadas por meio de políticas públicas de saúde ao idoso e à população em geral. Nesse contexto, a judicialização da saúde gera elevada tensão à harmonia entre as funções do poder estatal em razão do poder colocado nas mãos do Judiciário para resolução de causas e conflitos que deveriam ser resolvidos por meios das demais funções do poder estatal. 
Contudo, apesar da judicialização da política pública de saúde ser importante no reconhecimento do direito fundamental à saúde, ante a omissão do executivo e do legislativo, deve ser utilizado com moderação, como uma espécie de última alternativa, de forma a evitar a sobrecarga do Poder Judiciário, bem como uma possível violação ao princípio da separação dos poderes. ${ }^{127}$

O aumento nas demandas em saúde incitado por esse fenômeno de judicialização tem apontado para uma modificação nos gastos com realocação dos recursos, o que se torna evidente, sobretudo, em face a crise no sistema econômico. ${ }^{128}$

Os gastos do governo para cumprir determinações judiciais estão batendo recordes: estima-se que em 2016 o Governo Federal tenha gastado com medicamentos o montante de R\$1,6 bilhão com pacientes que buscaram a judicialização. Esse número foi de R\$ 800 milhões em 2014 e de R\$ 1,2 bilhão em 2015, a cada ano, essa despesa alcança patamares ainda maiores e o citado valor equivale a $10 \%$ do montante que o governo investiu em 2015 na compra de medicamentos previstos na rede pública para atender toda a população brasileira.

Uma forma de diminuir esses gastos, além de adotar uma gestão eficiente que evite a falta de medicamentos previstos no SUS, é a inclusão de novos tratamentos na rede pública de saúde. De acordo estudo da Associação da Indústria Farmacêutica de Pesquisa (Interfarma), a recusa de incorporações por parte do Ministério da Saúde estimula a judicialização e obriga o Estado a adquirir produtos com preços mais altos. A principal consequência disso é um gasto de cerca de quatro vezes maior per capita para aquisição de medicamento individual, quando comparado a um paciente com acesso ao medicamento pelo SUS. ${ }^{129}$

Outra possibilidade que vem sendo apontada é a tentativa de solução dos conflitos de interesse em matéria de saúde pública é a utilização dos meios alternativos extrajudiciais ou como também chamado da jurisdição multiportas, a fim de evitar-se a jurisdição enquanto única forma de resolvê-los e com isso dar efetividade ao direito fundamental à saúde, garantido na Constituição Federal.

\footnotetext{
127Disponível em: https://samealuz.jusbrasil.com.br/artigos/389418859/o-fenomeno-da-judicializacao-nasociedade-contemporanea. Acesso em: 19 de setembro de 2019.

128Disponível em: http://rebrats.saude.gov.br/destaques/265-litigios-judiciais-em-saude. Acesso em: 19 de setembro de 2019.

${ }^{129}$ Disponível em: http://www.femama.org.br/pacientesnocontrole/o-que-e-judicializacao-em-saude/ Acesso em 19/09/2019.
} 


\section{REFERÊNCIA}

[1] BAHIA, Alexandre, BACHA e SILVA, Diogo, et al. Processo e constituição: estudos sobre judicialização da saúde, da educação e dos direitos homoafetivos. Rio de Janeiro, 2015.

[2] CIRICO, Priscila Freitas; RESNER, Andrea Aparecida Ribeiro e RACHED, Chennyfer Dobbins Abi. OS IMPACTOS DA JUDICIALIZAÇÃO NA SAÚDE SUPLEMENTAR. Revista Gestão em Foco - Edição no 11 - Ano: 2019.

[3] CURY, Ieda Tatiana. Direito Fundamental à saúde: Evolução, Normatização e Efetividade. 8ª ed., Rio de Janeiro: Lumen Juris, 2005.

[4] NOGUEIRA, Gustavo. A coletivização das demandas individuais no NCPC e sua convivência com as demandas coletivas. Revista de Processo, 2016.

[5] BRASIL. Tribunal de Justiça do Estado de São Paulo. Disponível em: http://www.tjsp.jus.br/ Acesso em: 18 de setembro de 2019.

[6] BRASIL. Ministério da Saúde Disponível em: http://www.saude.gov.br/noticias/agencia-saude/43910judicializacao-da-saude-no-brasil-e-tema-de-debate-com-autoridade Acesso em 18 de setembro de 2019.

[7] BRASIL. Superior Tribunal de Justiça. Disponível em:

http://www.stj.jus.br/repetitivos/temas_repetitivos/pesquisa.jsp\&l=1\&i=952\&tt=T. Acesso em: 30 de maio de 2019.

[8] BRASIL. SupremoTribunalFederal. Disponívelem: http://www.stf.jus.br/portal/jurisprudenciaRepercussao/verAndamentoProcesso.aspincidente=3959903\&numeroPr ocesso $=630852 \&$ classeProcesso=RE\&numeroTema=381. Acesso em: 30 de junho de 2020

[9] INSPER. Judicialização da Saúde no Brasil: perfil das demandas, causas e propostas de soluções. Disponível em: https://static.poder360.com.br/2019/03/relatorio-judicializacao-saude-Insper-CNJ.pdf Acesso em: 18 de setembro de 2019.

[10] JUSBRASIL. 0 fenômeno da judicialização na sociedade contemporânea. Disponível em: https://samealuz.jusbrasil.com.br/artigos/389418859/o-fenomeno-da-judicializacao-na-sociedade-contemporanea. Acesso em: 19 de setembro de 2019.

[11] REBRATS. Judicialização. Disponível em: http://rebrats.saude.gov.br/destaques/265-litigios-judiciais-emsaude. Acesso em: 19 de setembro de 2019.

[12] FEMAMA. O que é judicialização da Saúde. Disponível em:

http://www.femama.org.br/pacientesnocontrole/o-que-e-judicializacao-em-saude/. Acesso em 19/09/2019. 


\section{Capítulo 6}

\section{Conclusão}

\section{Renzzo Fonseca Romano}




\section{CONCLUSÃO ${ }^{130}$}

O direito à saúde do idoso, como visto, constitui-se como direito fundamental de um grupo social que cresce de maneira significativa e possui ampla proteção no ordenamento jurídico brasileiro e no direito internacional. Dos tratados internacionais, passando pela Constituição Federal do Brasil ao Estatuto do Idoso e legislação previdenciária, verifica-se a existência de regras e princípios que tutelam o direito do idoso de maneira adequada.

Em razão dessa preocupação justificável, uma ampla rede de atendimento e apoio foi pensada e de alguma forma implementada no Brasil nas várias esferas da federação, embora ainda sejam insuficientes as políticas públicas para esse grupo social vulnerável, especialmente no plano da eficácia do direito à Saúde.

Em consequência, a função jurisdicional exercida pelo Poder Judiciário vem sendo, constantemente, sobrecarregada com demandas individuais e coletivas que, no contexto geral daquilo que se convencionou chamar de judicialização da saúde, para qual contribui, definitivamente, o desrespeito ou a omissão do Estado Brasileiro quanto à tutela do direito à saúde do idoso, tem gerado impacto significativo sobre as contas e alocação de recursos públicos.

Nesse contexto, no exercício de sua competência constitucionalmente assegurada e em razão da impossibilidade de negar o exercício da jurisdição (non liquet), o Judiciário tem sido chamado a solucionar demandas que vão desde a oferta de remédios pela rede pública, procedimentos cirúrgicos e terapêuticos experimentais à discussão no âmbito de planos de saúde sobre valores e cobertura.

Como se infere da pesquisa realizada, isso ocorre em razão da ineficiência das políticas públicas que geram um hiato entre a tutela do direito à saúde do idoso e sua eficácia social, ou seja, os meios pensados para atender o grupo social dos idosos não são disponibilizados pelas políticas públicas o que resulta em frustração, senão total, ao menos parcial dos fins pretendidos pelo ordenamento jurídico brasileiro e, ainda, em tensão entre a funções do poder estatal uma vez que o Judiciário é acusado de ativismo judicial ao atuar em resposta a tais demandas.

Por outro lado, a falta de informação do idoso também impacta sobre a tutela de seus direitos. Se a ninguém é dado descumprir a lei em razão de seu desconhecimento, considerando sua publicação, o desconhecimento sobre direito importa em seu não exercício.

Nesse contexto, a pesquisa de campo realizada na comunidade Colônia Antônio Aleixo em Manaus, estruturada a partir de metodologia própria e realizada por meio questionário sócio-econômico, que foi construído com sugestões dadas pelo Instituto Brasileiro de Geografia e Estatística - IBGE, embora não tenha atingido amostra mínima da população da área em que feita a pesquisa em razão da baixa participação do próprio público alvo, revela indicações que, apesar de não se afirmarem como resultado estatístico sustentável em determinado intervalo de confiança, apontam para a necessidade de um aprofundamento da investigação.

Dentre o grupo pesquisado, a faixa etária abrangia idosos entre 60 e 100 anos, consoante quadro abaixo:

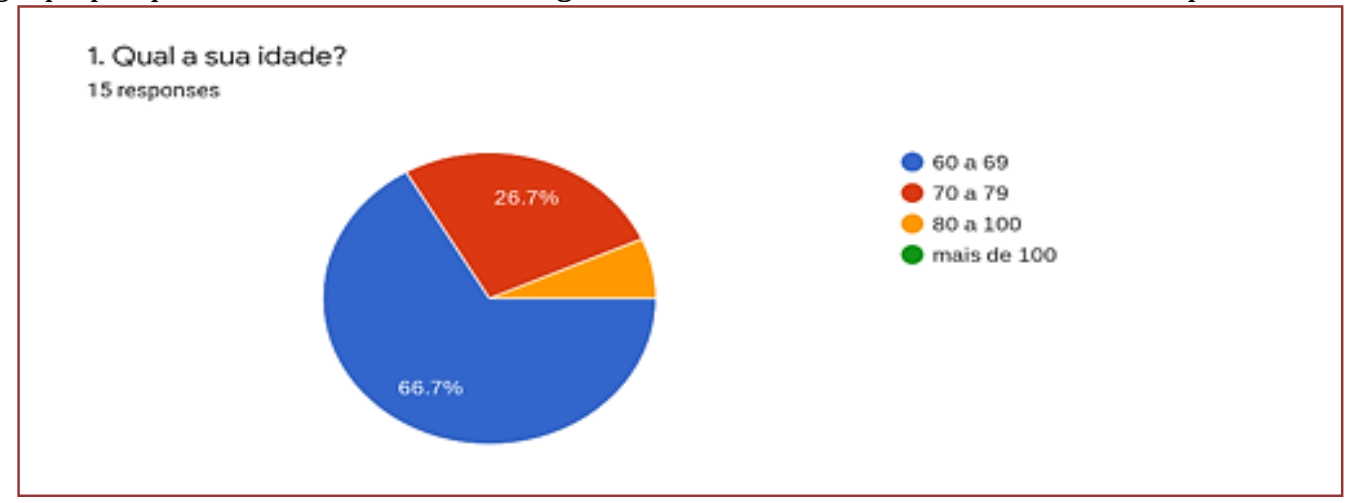

130 A Conclusão foi redigida por Renzzo Fonseca Romano, especialista em Teoria e Filosofia do Direito pela Pontifícia Universidade Católica de Minas Gerais - PUC/MG e em Direito Tributário e Social da Empresa pela Fundação Getúlio Vargas - FGV. Professor do Curso de Direito do Centro Universitário Ceuni-Fametro. 
Do grupo indicado, 93,3 \% informou utilizar os serviços públicos de saúde, de acordo com o gráfico colacionado abaixo:

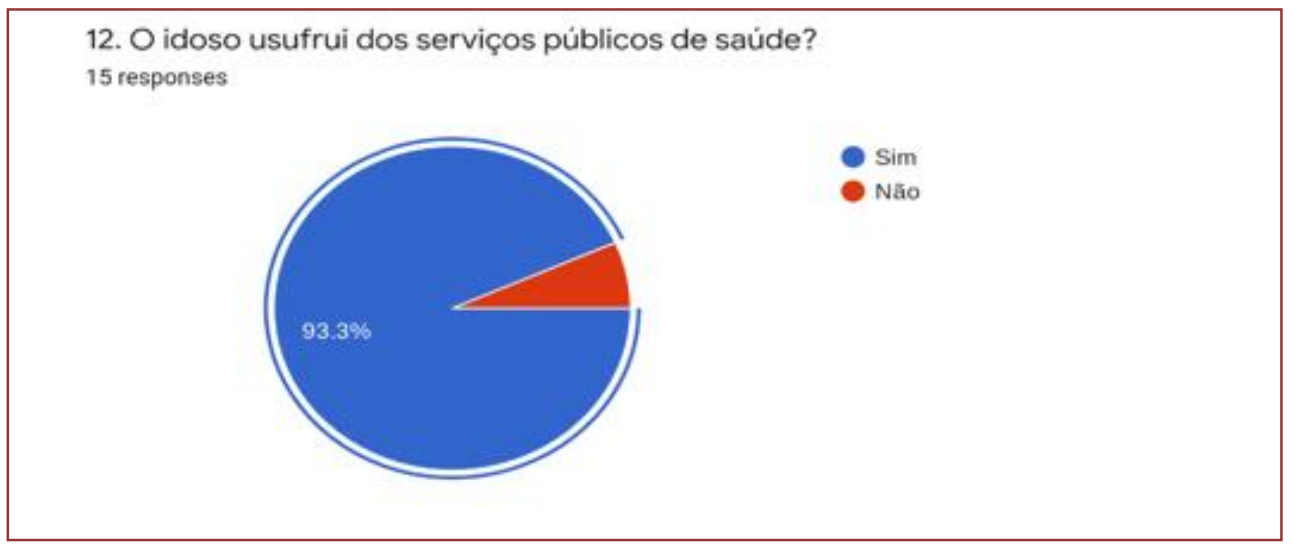

Sobre a obtenção de medicamentos para tratamento de saúde, 40\% recebe do serviço público, 40\% adquiri em drogarias comerciais e $20 \%$ recebe em doação, como revela o gráfico abaixo:

14. Como é adquirida a medicação para o idoso

15 responses

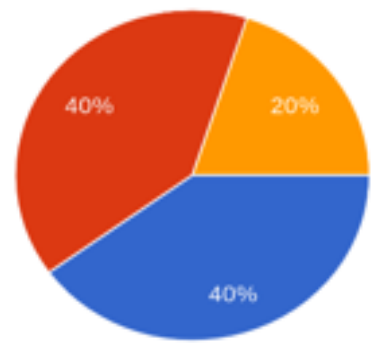

Recebe da farmácia da rede pública (CEMA)

Compra na drogaria

- Recebe por doaçấo

Sobre a opinião relativa aos serviços de saúde destinadas ao idoso, 60\% dos entrevistados afirmaram ser péssimo, 26,7\% reconheceram que são bons:

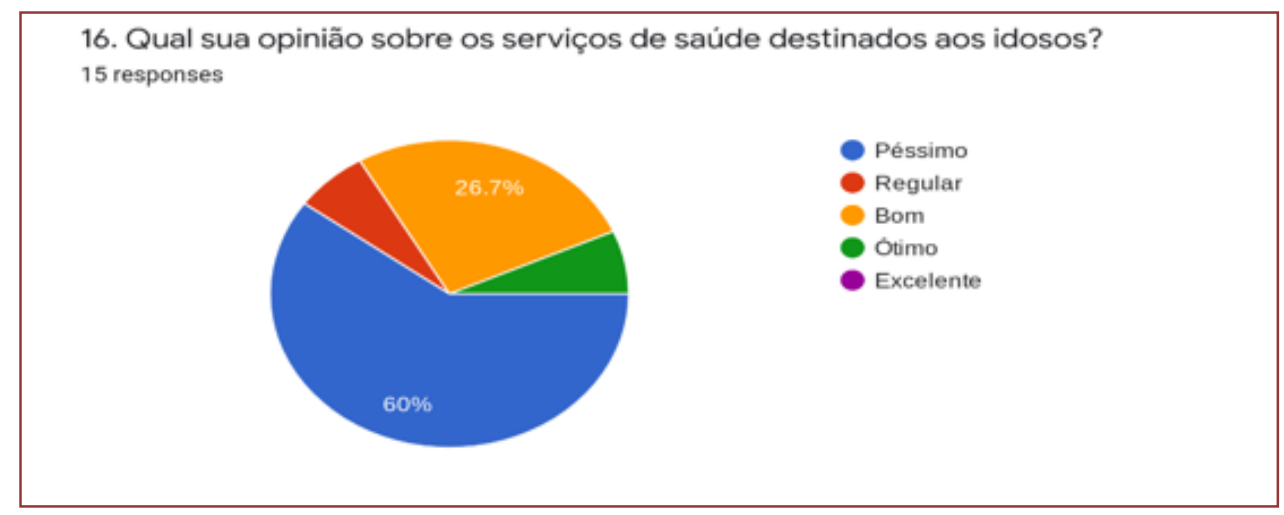

A respeito de ter ou não conhecimento sobre órgãos de defesa do direito do idoso ou de atendimento, obteve-se a seguinte resposta: 


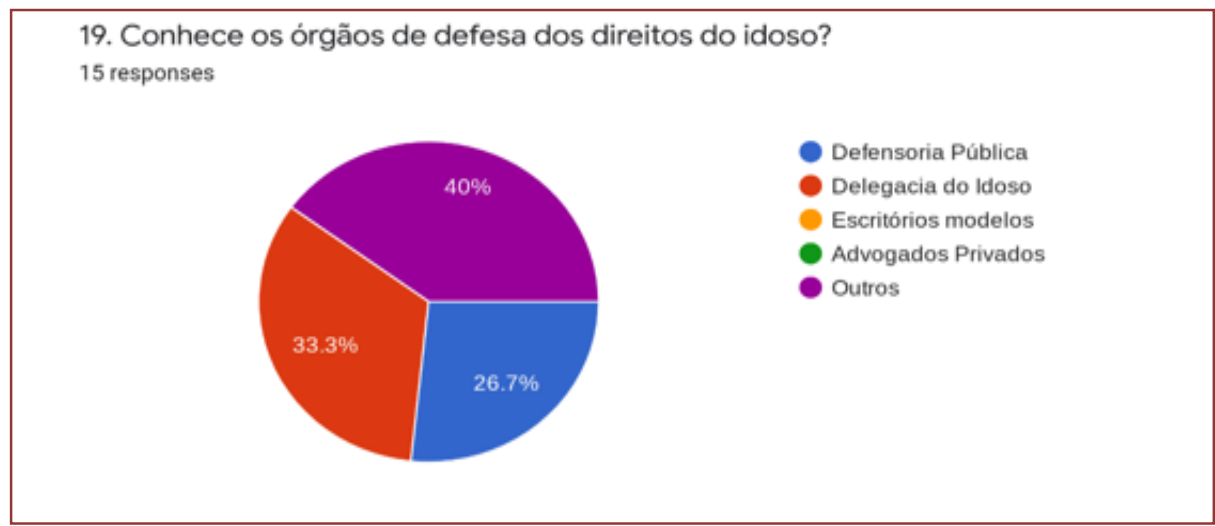

E, ainda, quando perguntados de ingressaram com alguma demanda relativa ao direito saúde, responderam que:

20. Já entrou com ação judicial pertinente à saúde?

15 responses

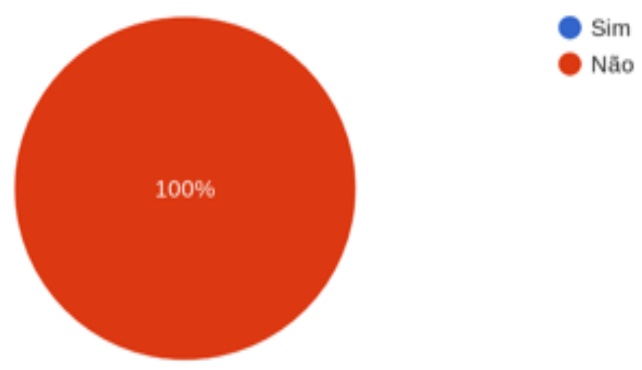

Portanto, o que temos como indicação para aprofundamento da pesquisa realizada é que, embora maioria do grupo investigado utilize os serviços públicos de saúde, há possíveis problemas de qualidade e no fornecimento de medicamentos, bem como no conhecimento e no exercício do direito fundamental à saúde do idoso por canais institucionais do Estado, uma vez que apesar de minimamente conhecidos, não são acionados para fins de demanda judicial, o que, em tese, ainda que de maneira superficial e não conclusiva, indica uma demanda reprimida, que poderá aumentar a sobrecarga do Judiciário. 
